\title{
An analysis of fragmented land-use *policy and land-use change: The case study of metropolitan Pittsburgh
}

Richard J. Hoch

West Virginia University

Follow this and additional works at: https://researchrepository.wvu.edu/etd

\section{Recommended Citation}

Hoch, Richard J., "An analysis of fragmented land-use *policy and land-use change: The case study of metropolitan Pittsburgh" (2005). Graduate Theses, Dissertations, and Problem Reports. 4156.

https://researchrepository.wvu.edu/etd/4156

This Dissertation is protected by copyright and/or related rights. It has been brought to you by the The Research Repository @ WVU with permission from the rights-holder(s). You are free to use this Dissertation in any way that is permitted by the copyright and related rights legislation that applies to your use. For other uses you must obtain permission from the rights-holder(s) directly, unless additional rights are indicated by a Creative Commons license in the record and/ or on the work itself. This Dissertation has been accepted for inclusion in WVU Graduate Theses, Dissertations, and Problem Reports collection by an authorized administrator of The Research Repository @ WVU.

For more information, please contact researchrepository@mail.wvu.edu. 
An Analysis of Fragmented Land-use Policy and Land-use Change:

The Case Study of Metropolitan Pittsburgh

\author{
Richard J. Hoch
}

Dissertation submitted to the College of Arts and Sciences at West Virginia University in partial fulfillment of the requirements for the degree of

\author{
Doctor of Philosophy \\ in \\ Geography \\ Robert Q. Hanham, Ph.D., Chair \\ Calvin O. Masilela, Ph.D. \\ Edward K. Muller, Ph.D. \\ M. Duane Nellis, Ph.D. \\ Timothy A. Warner, Ph.D.
}

Department of Geology and Geography

Morgantown, West Virginia

2005

Keywords: Urban land-use, land-use planning policy, uneven development, Pittsburgh

Copyright 2005 Richard J. Hoch 
This page left intentionally blank. 


\section{Abstract \\ An Analysis of Fragmented Land-use Policy and Land-use Change: \\ The Case Study of Metropolitan Pittsburgh}

\section{Richard J. Hoch}

This research examines the relationship between remotely sensed land-use changes and particular land-use policies within metropolitan Pittsburgh, Pennsylvania from 1992 to 2002. During the 1990's the Pittsburgh region experienced a tremendous expansion of residential and urban land-use change while simultaneously experiencing a population decline. Within the metropolitan Pittsburgh area there are 525 local and independent municipal governments with the legislative right to enact or not to enact land-use planning policies enabled by the Pennsylvania Municipal Planning Code. This fragmentation creates uneven intra-urban development patterns at the urban scale. This research demonstrates that certain land-use changes that occurred during the study period share statistical relationships with certain land-use policies in the study area. The procedure to identify these relationships was twofold. First, a change detection analysis (CDA) of remotely sensed images of Pittsburgh acquired by Landsat satellites in October of 1992 and 2002 was conducted in order to determine the quantitative and spatial extent of land-use change within each municipality in the study area. The second step involved a logistic regression model used to determine the likelihood of the presence or absence of individual planning tools for each type of land-use change. The four planning tools examined in this research were, 1.) a comprehensive plan, 2.) zoning ordinance, 3.) subdivision regulation, and 4.) a planning commission. Results of this analysis are reported in terms of the global coefficients and the local characterization of some individual municipalities. 
This page left intentionally blank. 
Dedication

To my Mother:

Maria Carmella

To my Father:

Albert, Jr.

To my Brothers:

Albert, III

Virgil Wade

Keith Allen 
This page left intentionally blank. 


\section{Acknowledgments}

I must acknowledge my family: without them I would have nothing. I would like to thank Mildred Miles for teaching me how to read, and to Madeline Steffanic for teaching me right from wrong. I would like to thank my Aunts' Frances and Rose for telephoning me at exactly the times when I needed it most; to all of my friends (Ryan, David, Brian, Sam, Terry and Chris to name a few) who put up with my mania about social theory and my hysteria when I considered the uncertainty of what was ahead of me; to Daniel Shelly, $\mathrm{PhD}$ and John Tremba, two of my public school teachers who instilled my interest in learning. All of the staff, both here and gone, at Hutch's Tap Room, not only for all of the wonderful support and encouragement over the years, but also for providing me a place that I could always go home to. To all of my PhD candidate colleagues at West Virginia University (Shawn, Scott, Eric, Jesse, Sue, Francis, Wilbert, Paddington, Ram, Seela and Abdullah (again, to name a few), all of which together created the most enriching and fulfilling experience of a lifetime; to all of the faculty and staff in the Department of Geology and Geography; and to Allison Hanham for fielding all of my late-night telephone calls.

Other acknowledgments include West Virginia View for the wonderful (and free!) data access it provides; Kirk Brethauer of the Southwestern Pennsylvania Commission for providing much of my data needs (and years of optimism); to Jonathan Johnson of the Center for Rural Pennsylvania; my former colleagues- Jim Prisk, Tom Page and Dan Nulph; and my current colleagues and friends at the Canaan Valley Institute, and the organization as a whole for the professional and personal support.

To my committee members; Doctors' Calvin O. Masilela, Edward K. Muller, .M. Duane Nellis and Timothy A. Warner - the four best mentors and best friends a person can find. And most of all to my committee chairman, Dr. Robert Q. Hanham who held my hand through my very darkest times.

Thank you all, I would never have been able to attempt it without you! 
This page left intentionally blank. 


\section{- TABLE OF CONTENTS -}

CHAPTER 1 - Introduction ............................................................................................. 1

CHAPTER 2 - The Urbanization Process........................................................................... 7

Urbanization as an Uneven Process of (Economic) Development ..................................8

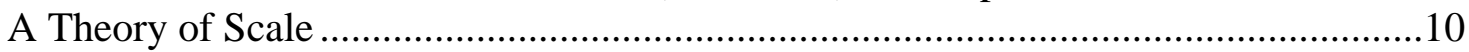

The Production of (Urban) Scale .......................................................................... 11

The Politics of (Urban) Scale ................................................................................. 13

Urban Regimes as Economic Crisis Managers; or the New Urban Politics ...................14

From Urban Governments to Urban Governance ........................................................18

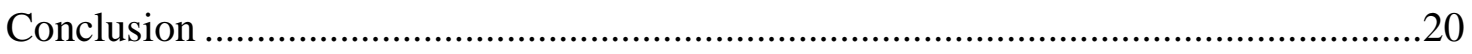

CHAPTER 3 - Planning Paradigms in Theory and Practice ......................................... 23

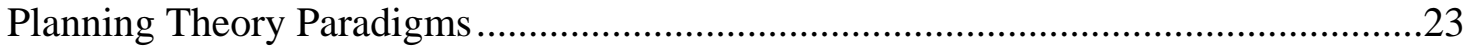

Modernity (Rationality) ..................................................................................... 24

(Post) Modernity ……………………............................................................ 27

Planning Practice Paradigms.........................................................................................31

The Dilemma of Sustainable Development ............................................................ 31

Planning for Profit: The Privatization of Planning ................................................. 34

Planning as a Product ......................................................................................... 36

Contemporary Trends ....................................................................................... 38

CHAPTER 4 - Historical Background ................................................................................. 41

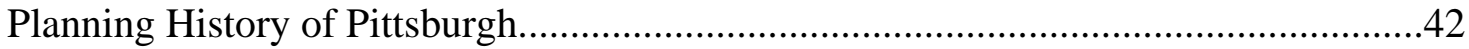

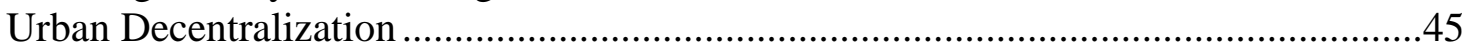

Geographic Industrialization................................................................................. 47

Capital Real Estate Investments ............................................................................ 49

Public-Private Partnerships ................................................................................. 50

CHAPTER 5 - Research Design........................................................................... 53

Research Objectives............................................................................................53

Remote Sensing Analysis - Change Detection.............................................................54

Change Detection Analysis Background ............................................................. 54

Analyzing Remote Sensing Information with Secondary Data .................................. 55

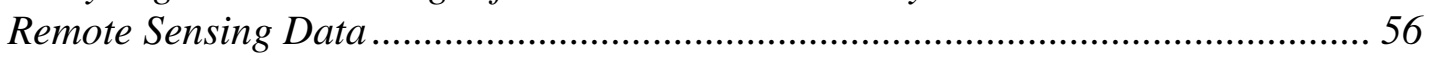

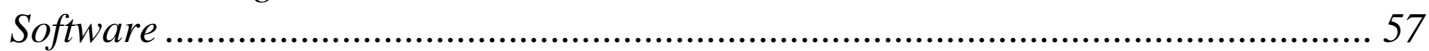

Supervised Classification................................................................................. 57

Overlay Image Differencing (Matrix Analysis) ........................................................ 59

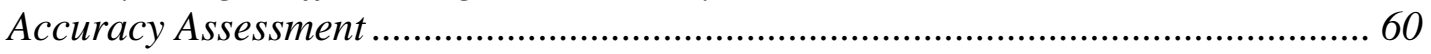

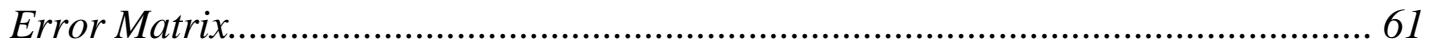

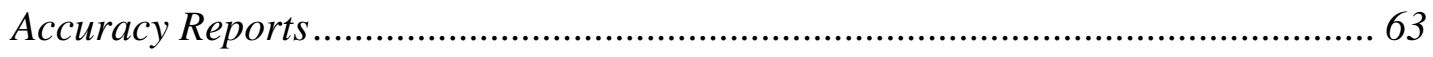

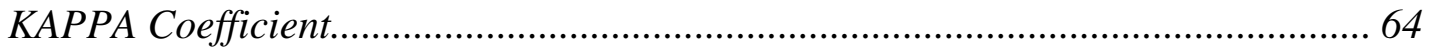

Statistical Analysis - Logistic Regression...................................................................65 


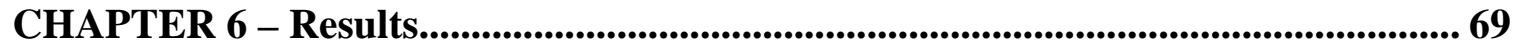

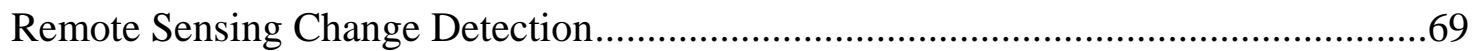

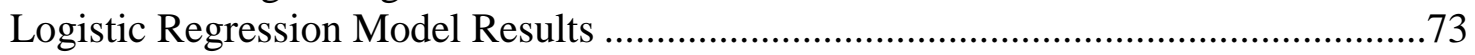

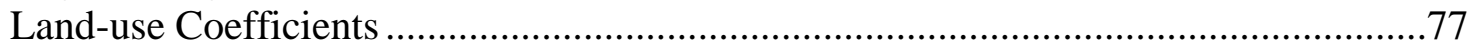

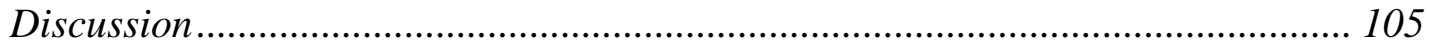

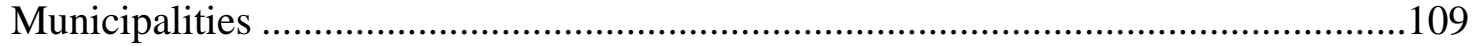

Forest to development................................................................................... 110

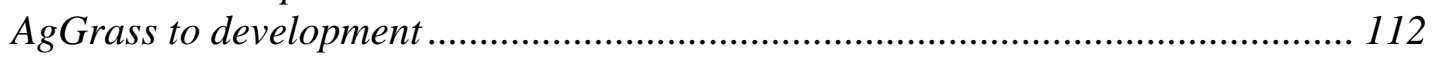

Residential to urban .................................................................................... 115

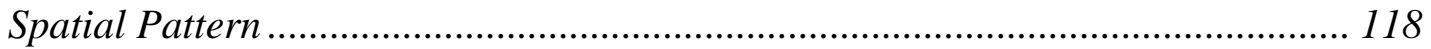

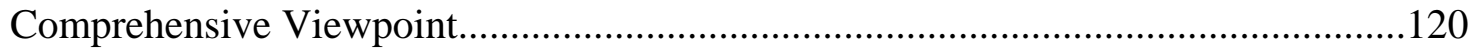

CHAPTER 7 - Conclusion ........................................................................................... 123

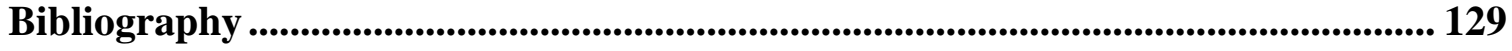




\section{List of Tables}

Table 1 - Land-use Categories

Table 2 - 1992 Error Matrix

Table 3 - 2002 Error Matrix

Table 4 - 1992 Accuracy Totals

Table 5 - 2002 Accuracy Totals

Table 6 - 1992 KAPPA Coefficients

Table 7 - 2002 KAPPA Coefficients

Table 8 - Pixel Distribution by Class

Table 9 - Acre Distribution by Class

Table 10 - Class Change Distribution by Pixel Count (Percentage)

Table 11 - Class Change Distribution by Acre (Percentage)

Table 12 - Logistic Regression Results

Table 13 - Developed to Less-developed Coefficients

Table 14 - Less-developed to Developed Coefficients

Table 15 - Urban to Residential Coefficients

Table 16 - Urban to Forest Coefficients

Table 17 - Urban to AgGrass Coefficients

Table 18 - Residential to Urban Coefficients

Table 19 - Residential to Forest Coefficients

Table 20 - Residential to AgGrass Coefficients

Table 21 - Forest to Urban Coefficients

Table 22 - Forest to Residential Coefficients

Table 23 - Forest to AgGrass Coefficients

Table 24 - AgGrass to Urban Coefficients

Table 25 - AgGrass to Residential Coefficients

Table 26 - AgGrass to Forest Coefficients

Table 27 - Comprehensive Plan Ranked Coefficients

Table 28 - Zoning Ranked Coefficients

Table 29 - Subdivision Ranked Coefficients

Table 30 - Planning Commission Ranked Coefficients

Table 31 - Top 20 municipalities over 5 sq. mi. that experienced from Forest to 'Development'

Table 32 - Top 20 municipalities over 5 sq. mi. that experienced from AgGrass to 'Development'

Table 33 - Top 20 municipalities over 5 sq. mi. that experienced from Residential to Urban 
This page left intentionally blank. 


\section{List of Figures}

Figure 1 - Study Area

Figure 2 - "The Region Is a Product"

Figure 3- William Penn's Philadelphia Plan

Figure 4 - Land-use Change Transitions

Figure 5 - Comprehensive Plan (2001)

Figure 7 - Zoning Ordinance (2001)

Figure 6 - Subdivision Regulation (2001)

Figure 8 - Planning Commission (2001)

Figure 9 - Developed to Less-developed Change Transition

Figure 10 - Less-developed to Developed Change Transition

Figure 11 - Urban to Residential Change Transition

Figure 12 - Urban to Forest Change Transition

Figure 13 - Urban to AgGrass Change Transition

Figure 14 - Residential to Urban Change Transition

Figure 15 - Residential to Forest Change Transition

Figure 16 - Residential to AgGrass Change Transition

Figure 17 - Forest to Urban Change Transition

Figure 18 - Forest to Residential Change Transition

Figure 19 - Forest to AgGrass Change Transition

Figure 20 - AgGrass to Urban Change Transition

Figure 21 - AgGrass to Residential Change Transition

Figure 22 - AgGrass to Forest Change Transition

Figure 23 - Top 20 municipalities over 5 sq. mi. that experienced from Forest to 'Development' Figure 24 - Top 20 municipalities over 5 sq. mi. that experienced from AgGrass to 'Development' Figure25 - Top 20 municipalities over 5 sq. mi. that experienced from Residential to Urban Figure 26 - Developing (Urbanizing) Municipalities 
This page left intentionally blank. 


\section{CHAPTER 1 - Introduction}

Pennsylvania’s fragmented political structure composed of cities, towns, townships and boroughs creates an uneven planning-policy geography at the local level. This fragmentation has led to decades of unregulated development throughout the greater Pittsburgh area by private industrialists. For most of the twentieth century, struggles between public and private interests ensued as to which sector would direct the future of Pittsburgh’s physical, political and economic growth.

Direct attempts by the public sector and many indirect attempts by the private sector all experienced moderate success in controlling the physical, political and economic transformations that Pittsburgh experienced during most of the $20^{\text {th }}$ century. Later in the century, partnerships between the public and private sectors were formed to coordinate these processes. These public-private partnerships shared success partially due to the public sector's legislative authority in adopting policy, and partly due to the private sector's geographic freedom to elude regulation from the Commonwealth of Pennsylvania’s fragmented political framework.

After decades of debate and struggle about how to manage the 'industrial district' known as Pittsburgh, the only authority yet to be established as a regional planning unit is a Metropolitan Planning Organization (MPO). MPO’s are organizations mandated by the federal government to oversee and administer federal transportation funds. The pivotal policy action that led to metropolitan planning initiatives was the Highway Act of 1962. Prior to this, regional and metropolitan planning bodies existed, but had little or no authoritative role in the decision-making process. This Act made federal highway dollars contingent to those areas with populations over 50,000 by requiring such areas to 
establish "a continuing and comprehensive transportation planning policy process carried out cooperatively by states and local communities” (Solof, 1996) ${ }^{1}$. This process become known as 'three - C's' planning and continues to be followed to this day. The establishment of MPO's as they currently exist took over two decades to fortify. Following the federal housing acts of the 1950's, the highway acts of the 1960's and the environmental acts of the 1970's, the need for a formal authoritative organization became evident, as compliance with social and environmental policies became increasingly comprehensive and bureaucratic.

The name of Pittsburgh’s MPO is the Southwestern Pennsylvania Commission $(\mathrm{SPC})^{2}$. Within the nine-county area planned by the SPC there are 525 local municipalities. The SPC's mission is 'the cooperative forum for regional collaboration, planning, and public decision-making' and it's main purpose is to help this region plan for the future by working to improve the transportation system, implementing economic development initiatives, and assisting local governments.

Local municipalities, however, are left with the actual task of community, conservation, and economic development planning. Local municipal governments are not, however, mandated by the state government to adopt land-use planning tools, but are empowered to do so by the Pennsylvania Municipal Planning Code (MPC). Therefore, guidelines are not set to dictate local planning policy, resulting in uneven intra-urban

\footnotetext{
${ }^{1}$ For a chronology of the federal legislative acts that led to the establishment of MPO's, see Solof's, History of MPO's, Parts I - IV. Originally published in consecutive issues of NJTPA Quarterly starting in the July 1996 edition. Also available online at http://www.njtpa.org/public_affairs/mpo history

${ }^{2}$ The Pittsburgh MPO previously operated under the name 'Southwestern Pennsylvania Regional Planning Commission (SPRPC).
} 
development patterns. The nine-county area adopted by the SPC as its service region is the study area for this research ${ }^{3}$ (Figure 1).

Figure 1 - Study Area

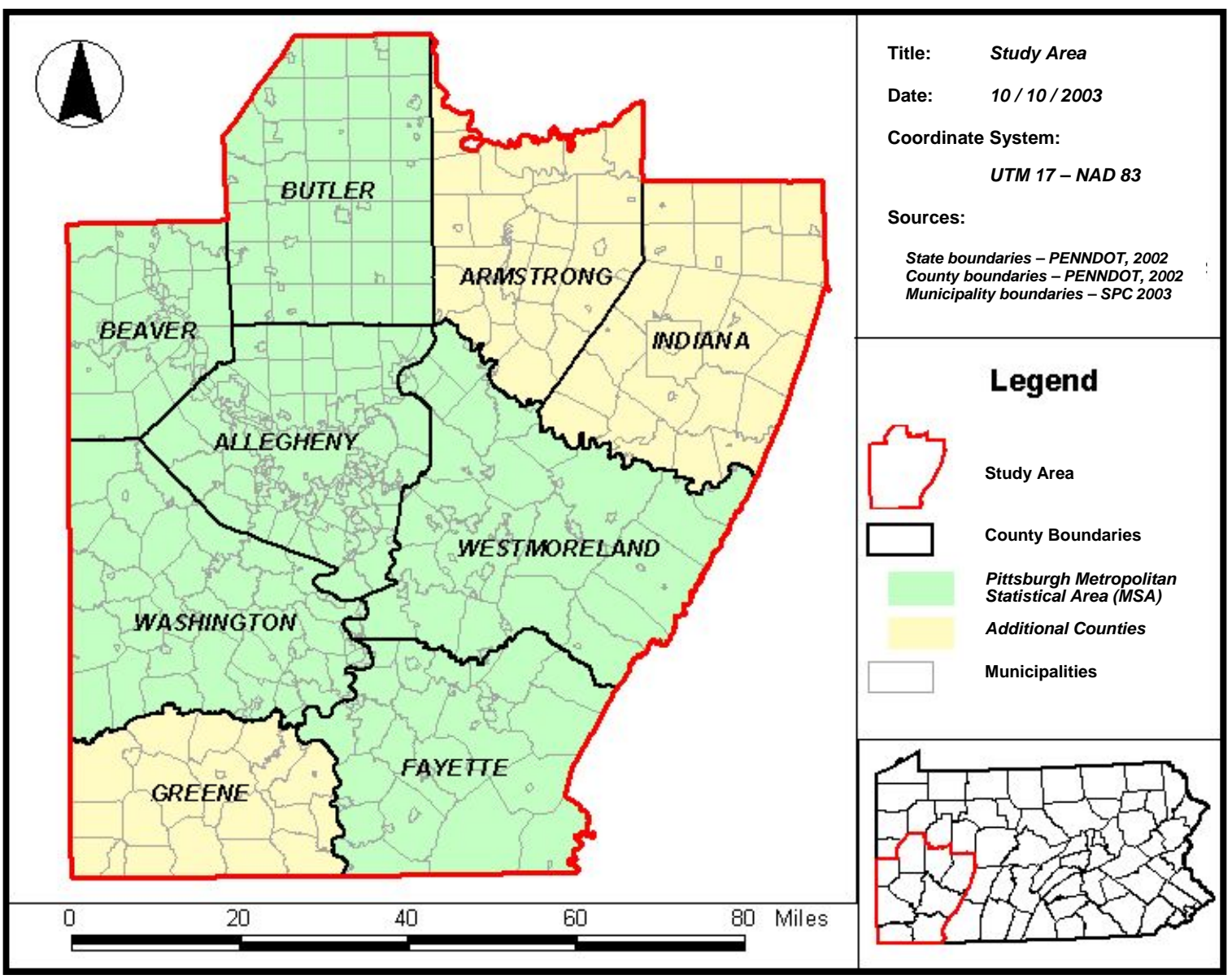

Despite the national mandate for metropolitan planning institutions, the practice

of comprehensive planning has faded as the predominant planning practice during the last

30 years. Postmodern influences have encouraged the concept of 'consensus through

collaboration' as the prevalent contemporary planning model. This postmodern shift has

further been supported as a result of the trend towards the privatization of land-use

3 The study area is the nine-county area consisting of Allegheny, Armstrong, Beaver, Butler, Fayette, Greene, Indiana, Washington and Westmoreland counties. At the time this research began, these 9 counties comprise the Pittsburgh MPO (the Southwestern Pennsylvania Commission) planning area. Recently, Lawrence County was added as a $10^{\text {th }}$ county in the Pittsburgh metropolitan area. 
planning. The trend of planning being a practice performed by for-profit planning firms in lieu of government agencies - a practice that increasingly focuses on the most advantageous scenario for the most local unit - compounds the race to-the-bottom traps of uneven intra-urban development.

The population of Southwestern Pennsylvania has been declining since the 1960’s and the current population count is close to what it was in the 1940's. During the 1990's nearly every US metropolitan region experienced tremendous economic growth. Pittsburgh, however, did not. The one trend that Pittsburgh did follow during the 1990's was the consumption of undeveloped land. According data produced by the US Department of Agriculture, between the years 1982 and 1997 Pittsburgh developed "nearly half (43 percent) as much land as had been previously developed... despite a regional population decline of 8 percent” (from Sustainable Pittsburgh, 2002). This contextual and historical chain of events has led Pittsburgh to the point where it is possible that it ranks number one in sprawl during the 1990's when taking into account the region's population decline.

“...Pittsburgh did not perform very well in the 1990's. Pittsburgh, in fact, could be considered one of the worst sprawling places in the country."

Bruce Katz

Senior Fellow, the Brookings Institute ${ }^{4}$

In 2003, The Brookings Institution Center on Urban and Metropolitan Policy released, 'Back to prosperity, a competitive agenda for renewing Pennsylvania' which addressed Pennsylvania's current status in regards to population, taxes, jobs and land-use. According to this report, “Among the nation's largest metropolitan regions no area can

\footnotetext{
${ }^{4}$ Pittsburgh Post-Gazette, June 08, 2001 “Scholar says area sprawl worse than L.A.’s”.
} 
compete with Pittsburgh for profligate land consumption per household” (p.47). This statement is supported by the facts that "Metropolitan Pittsburgh developed an astonishing 202,000 acres of land - or 315 square miles of it - even though it lost 166,000 residents between 1982 and 1997 and gained just 24,000 households. This means the region urbanized an astounding 8.5 acres for every new household it added over the 15 years, compared to just 1.3 acres nationally”. These statistics lead the Brookings report to conclude, “This makes Pittsburgh by far the worst-sprawling large metropolitan area in the country” (p. 49).

The overall goal of this research is to analyze the relationship between local planning policy and land-use change in the Pittsburgh metropolitan region using remotely sensed imagery and to analyze this information utilizing statistical methods. The specific objectives of this research are:

- Identify changes in land-use within the municipalities of the Pittsburgh region by means of remote sensing change detection analysis, and

- Identify the relationship between local municipal planning policy tools with particular land-use changes throughout the Pittsburgh region by means of statistical analysis.

A post-classification comparison method of change detection analysis (CDA) was performed using two Landsat TM data sets. The dates of these images are October 02, 1992 and October 06, 2002. The results of the CDA were then be distributed by municipal unit. The amount and type of change in each municipality were then be tested 
with four land-use planning policy variables for each of the 525 municipalities within the study area. The four land-use planning policy variables used in this research will be 1.) zoning ordinance, 2.) subdivision regulation, 3.) comprehensive plan, and 4.) planning commission. These four planning tools have been identified as the most basic and primary of the set of tools that local governments are empowered to use under the Pennsylvania Municipal Planning Code (Center for Rural Pennsylvania, 2001). Many local municipalities in the Pittsburgh region have not enacted all or even some of these foundational planning-tools, which they are entitled to do at their discretion.

The remainder of this research document is structured as follows: Chapter 2 provides background in the conceptual underpinnings of urbanization as an economic process and the endemic uneven development that occurs as a result of this process. Chapter 3 reviews contemporary issues pertaining to land-use planning and practice, including a discussion of the paradigm shift in contemporary planning theory and the privatization of land-use planning. Chapter 4 provides a brief overview of the documented historical processes that have manifested into Pittsburgh's land-use planning legacy. Chapter 5 will outline the research design where the data and software used will be reviewed, and the analysis methods will be discussed. Chapter 6 will explain the results of the case study with discussion and interpretation. Chapter 7 is the conclusion that discusses further research directions, some research limitations to the analysis, and final remarks. 


\section{CHAPTER 2 - The Urbanization Process}

This chapter discusses the conceptual literature pertaining to urbanization, and more specifically, urbanization as a political and economic process. Modern and postmodern urbanization processes are the result of the advanced capitalist modes of production that are dominant in industrial and post-industrial nation-states. Various and numerous scales are produced as a result of production and these scales provide units for geographic inquiry. The most abstract scales for inquiry are the global, the nation-state, and the local - often referred to as the urban in this framework. This research uses this urban scale as its unit of inquiry. However, like other scales, the urban scale also produces a variety of other nested scales in which other processes take place.

The remainder of this chapter will discuss a rethinking of urbanization in the United States, and shows us that the urbanization process can now be conceptualized as a process of uneven economic development, where urban areas must compete with one another. A theory of scale follows with a discussion of the production and the politics of scale, particularly as they pertain to the urban scale. There is then a discussion of how the urban scale functions in the global economy, as urban governments are decreasingly functioning in a state hierarchy and increasingly forced to operate in a global economic network interacting with multiple scales, and increasingly relegated to deal with local economic crises independently. Last is a discussion of the tendency of urban regimes to rely less and less on urban government to facilitate reproduction, but rely more on urban governance as a mechanism to ensure continued accumulation. 


\section{Urbanization as an Uneven Process of (Economic) Development}

Gordon (1977) identifies three historic forms of urbanization that took place in the US since it's colonial times. These forms correspond directly with the political economic view that capitalism has experienced three main stages of capital accumulation in the advanced capitalist nation states. These three forms and urban functions are: commercial accumulation/cities, industrial (or competitive) accumulation/cities, and corporate (or monopoly) accumulation/cities. Capitals’ continuous ‘creative destruction’ of the urban landscape in order to continue to produce and control the production of capital accumulation and the reproduction of labor has been extensively examined (Harvey, 1978, 1987, 1989a; Brenner, 1997; Smith, 2000).

Gordon (1977) offers a radical perspective of US urban development stating that decentralization and the population and economic shifts to the sunbelt cities was not simply 'progress' but was caused by capital's inability to control labor in the existing manufacturing centers during the post-industrial period. Gordon (1977) attempted to show that urban development in the US was a result of class struggles and how capital adapts to counter-maneuver such struggles. This argument is counter to the traditional historical explanation that cities change (decentralized or grew elsewhere) due to new investment in technology and primary circuit modes of production (plants and equipment). Gordon (1977) argues the opposite - that “an eruption of class struggle initially prompted the decentralization and, by implication, that the new plant and equipment developed as a result of the dispersal in order to permit corporations taking advantage of the new locational facts” (p. 78). Capitals' response to this class struggle during the 1970 s and 1980s was simply to move to other cities that did not mature during 
the industrial period therefore providing capital with more leverage over labor in these new locales. The ability of capital to move from its industrial 'local dependence' during the corporate stage of capitalist accumulation has also been extensively explored (Cox, 1988, 1993; Swyngedouw, 1997; Brenner, 1998; Smith, 1998).

To Harvey (1985), urban development manifests as a consequence of industrial capitalism. Harvey contends that urban development is in itself urbanization and that it is important to understand that urbanization is a process; a process implemented purely for the accumulation of profit by capital. In Harvey's words, "a class of capitalists is in command of the work process and organizes that process for the purpose of producing profit” (p. 101).

There is also a second theme that is crucial to the urbanization process; the conflict between the capitalist class and the working class, also known as the class struggle between capital and labor. The work process is the transformation of resources into products with added value. This transformation occurs by the work of human labor and the added value is derived from the difference between the wage earned by labor and the added value of that transformation. This surplus value is profit and the accumulation of profit is the goal of capitalism - therefore, in order to maximize accumulation, capital organizes this process, in its own interests. This organizing spatially manifests itself and leads to the creation of the built-environment, or more eloquently stated, "Capital represents itself in the form of a physical landscape created in its own image, created as use values to enhance the progressive accumulation of capital” (Harvey, 1985, p. 124). 


\section{A Theory of Scale}

Smith (1997) has urged that a contemporary theory of the production and the politics of scale be developed within geography. Smith begins the discussion of such a theory starting with Giddens (1984) work where he views space as a mosaic, perhaps more like a jigsaw puzzle that is constructed laterally. Smith contends that space is hierarchical rather than a mosaic and these spaces are essentially socially constructed scales. Smith contends that an essential question is '(if) social life operates in and constructs some sort of nested hierarchical space rather than a mosaic. How do we critically conceive of these various nested scales...?” (Smith, 1997, p. 72).

This questioning has led Smith to attempt the construction of a geographic theory of the politics of scale. In this attempt, Smith revisits the work of Henri Lefebvre (1991). Lefebvre actually conceptualizes two types of space - social space and state space. According to Brenner (1997), Lefebvre describes social space as "an ensemble of social relationships, not an object, a void, a container" (p. 104). State space consists of three things; territory, administrative and organizational hierarchies to configure interaction, and the construction of a mental state space that is manifest from everyday social consciousness. These distinctions are important to clarify when discussing scale, the state, space and the politics of scale. At times what has been discussed as scale in the literature sometimes mixes these two concepts of space simply as 'scale'. But Lefebvre makes the distinction that social space is not the container of social interaction, but the result of it, and that if any container of social interaction exists, then it is that of state space. 
Smith (1997) blurs the differences between Lefebvre’s two concepts of space.

Smith contends that while the two different types of space may exist, that essentially they are both scales of economic-social construction and, therefore, exist simultaneously in a nested hierarchy. In reference to the urban politics of this hierarchy, Smith writes, "the same capitalists that cooperate through the local state, chambers of commerce and local growth coalition, in establishing local conditions for the reproduction of labor bower, also compete for wage labor and for local markets. The production of scale is a central means by which capital is both contained and freed, provided with a territory and at the same time a global base” (p.72).

Smith (2002) later writes,

"the specific logics of capital accumulation embody equally specific geographies of economic expansion and that the unevenness of geographical development - between developed and underdeveloped areas on different spatial scales - owes not to geography in the old sense (differences in geographical endowment) but to the inherent logic of economic expansion per se" (prologue, p. xxi).

This theory of uneven development provides an analytical framework for the study of the geography of capitalism; understanding that scales are produced and dynamically related.

\section{The Production of (Urban) Scale}

It is the urbanization process that creates urban space therefore producing the urban scale - a scale that is constructed due to the relations of capital and labor. Scale is inherently relative and if discussed independently of other scales, is therefore irrelevant (Jessup, in Brenner, 1997). Howitt (1998) defines the theory of scale as a concept of relations. This concept of scale is not a size or a level as has been argued and traditionally taken for granted, but this concept of scale is the extent of the interaction or relations between parties. Howitt (1998) distinguishes this concept from traditional definitions and "seek(s) to assert the importance of scale in a web of relationships between dialectically intertwined foundational concepts of co-equal importance” (p. 51). 
Smith (2002) builds on this concept of scale and offers his distinction of different kinds of scale and offers the explanation that scale is "not only material scale worded and reworded as landscape but it is also the scale of resolution or abstraction which we employ for understanding social relationships” (p. 75).

To preserve and continue accumulation, capital must adapt to the class struggle that occurs due to the exploitive nature of the work process. This struggle produces the urban scale of relation that is identified by the spatial extent of the dependence between local capital and labor. Further, the urbanization process creates urban scales partially by maximizing the extent of the labor market so as to input excess labor into the work process in order to keep wages low thus in effort to maximize profit. Thus, the urban footprint is the physical manifestation of capital's dominance of a labor-shed.

This scale/relation/struggle, is a dynamic one and each of the players involved (capital, labor, and the state) find ways to regulate the struggle in an attempt for control of power. One way that capital does this is to direct investment from the primary circuit to the secondary circuit of capital during periods of over accumulation crisis. This type or redirection of investment serves to alleviate over accumulation crisis while also, (1) facilitating the reproduction of labor, and (2) to establish a 'structural coherence' (Harvey, 1982). This structural coherence is a production of space; space with investment 'spatially fixed' for the purpose of continued accumulation.

The tactic of spatially embedding capital to facilitate accumulation does not necessarily mean that the class struggle is also 'spatially fixed'. Nor does it mean that the work process is temporally fixed. As Harvey (1982) states, 
'Under capitalism there is, then, a perpetual struggle in which capital builds a physical landscape appropriate to its own condition at a particular moment in time, only to have to destroy it, usually in the course of a crisis, at a subsequent point in time” (p. 124).

The Politics of (Urban) Scale

Capitalism's contradictory nature of seeking out infinite resources in a world of finite supply results in the constant production and reproduction of spaces for both production and consumption (Harvey, 1989b). Historically, this production inspired exploration and the settling of North America's western frontier. Recently, this contradiction presents itself as urban renewal, urban restructuring, and local economic (re)development.

The global economic transformation has delegated much of the nation-states former responsibilities to the urban scales. Such re-scaling is also a mechanism developed to counter the contradictions of capitalism and to offset oncoming economic crises. As Brenner (1997) states,

"Once capital circulation has been extensively globalized, there is no longer any single scale on which stabilized long-run accumulation can occur. The frontiers for crisis-displacement are thereby exhausted, leading capital to revalorize and recolonize the spaces it has already conquered in its restless search for new sources of surplus value"(p.154).

The re-colonization of already conquered space is the 'new frontier' for capital, which, according to Smith (2000) is popularly defined as urban re-development. These new frontiers are the urban scales of social relation; cities now transform and re-develop for capitalisms re-expansion. Prior to the global expansion of capital, economic expansion could mirror capitals absolute geographic expansion. As a result of the globalization of capital, economic expansion takes place not through absolute geographic expansion but thorough the 'internal differention’ of geographical space (Smith, 1990; 
2000). Smith (2000) argues that this internal differention materializes in urban renewal programs and redevelopment authorities, which are both precursors and responses to uneven development. Capital's need to structure and restructure urban space in order to continue accumulation is not new and in fact it is endemic in the urbanization process (Harvey, 1982; Brenner, 1997). "What is new” Smith (2000) adds, "is the degree to which this restructuring of space is an immediate and systematic component of a larger economic and social restructuring of advanced capitalist economies” (p. 344).

\section{Urban Regimes as Economic Crisis Managers; or the New Urban Politics}

Kevin Cox has contributed greatly to our understanding of the urban scale as a result of the politics of scale Smith argues above. The global politics of scale has transformed the function of the urban and urban politics. Cox's major conceptual contributions to this understanding are, 1) local dependence (with Mair, 1988), 2) the New Urban Politics (NUP) (1993), and 3) spaces of dependence and spaces of engagement (1998). What follows is a discussion of each of these concepts.

Developed from locality studies, Cox and Mair (1988) devised the concept of 'local dependence'. Local dependence is defined as the dependence of various actors (capitalist firms, the local state, local labor markets) on the reproduction of certain social relations within a particular territory. This dependence leads to local growth coalitions between public and private interests with the goal of stimulating local economic development. The local state, local labor unions and certain local industries are heavily invested in particular localities, which necessitate this new type of boosterism.

Potential conflicts arise from this kind of (loosely defined) solidarity of the various actors. While a sense of community is constructed by these coalitions through 
the actions of local economic development offices, local dependency leads to the inevitable conflict between other, competing localities that share a similar situation. Firms try to escape local dependence by developing strategies that free their capital from local dependence. One way firms do this is by geographically diversifying into multiple locations (what Cox is calling multilocationality) by spreading the risk of local economic fluctuations over space. Simply state another way, the more spatially widespread a firms investments, the less likelihood of total loss. Another way is to avoid the immobility of the built-environment all together by renting the local means of production rather than investing in their fixity. Certain types of industries are more adapt at the latter strategy than others. Utility companies, for example, are not able to rent their needed local means of production, as they are the provider of a form of capital's spatial fix to those firms that are capable. This spatial diversification strategy at avoiding local dependence is a model that can be employed by the emerging industries of service-based economic activities.

However, Cox and Mair (1988) view these attempts at avoiding local dependence as a temporary and scale-specific remedy (a time/space fix), which works at the metropolitan local-scale. According to Cox and Mair (1988) "Multilocationality is merely a temporary and scale-specific remedy" because "it only reconstitutes local dependence at some broader geographic scale (p. 309). Therefore, local dependence 'jumps scales’ as capital continues to globalize meaning that local dependence is not place specific but scale specific.

Capital's re-scaling of the state to defer crisis has resulted in the urban scale as the new crisis manager. Whereas global capital once relied on the underdeveloped world to shift crises where nation-states were subjected to a race to the bottom,, the rescaling of 
the state now enables this shift to occur at the urban scale. Mobile capital benefits from the local dependence of urban state structures, other firms still fixed by capital investment in particular localities, and local labor markets that are 'traditionally' locally dependent for their continued social reproduction (i.e., family, churches, and other local social support structures). The mobilization of capital resulting from the increasingly globalized system relegates the responsibility of social reproduction and economic development to the urban scale, thus pitting urban centers against each other in an interscale competition for resources.

This new competition between urban scales is what Cox $(1993,1995)$ refers to as the New Urban Politics (NUP). Cox criticizes the emerging literature on urban politics as being too focused on attracting local economic investment. The NUP is simply the new priority local urban politics place on local economic development. The scale of the NUP is now different [“Urban politics has become globalized...” (1995, p. 213)] and as a result of the globalization of capital "cities (now) compete with one another for investment” (p. 214). The NUP argument is based on the assumption that there is a power struggle between capital and local communities. The NUP, then, is driven by the competition that capitalism forwards to invent new competitive edges but in the long run net rates of return, to what Cox (1995) refers to as, "above merely the normal" and he admits that, "there is some truth to the NUP, but it is a very qualified one and risks being overextended” (p. 220). Cox criticizes the NUP by arguing that ultimately, "localities are essential non-substitutable resources in the appropriation of super-profits” (p. 219). Cox (1993) warns that, "the NUP is a body of ideas that is ideological in form and which may therefore mislead as to the essential character of US urban politics” (p. 447). 
Cox’s conceptualization is criticized by MacLeod and Goodwin (1990) for not acknowledging the "discourses, hegemonic ideologies and regulatory practices in and through which the scalar materialization of the state is constructed and how this, in turn, impacts back upon these relative dependencies” (p. 510) and by Jones and Judd (Cox, 1998) who claim that Cox fails to see the role that scale plays in capital accumulation. ${ }^{5}$

Cox (1998) responds to these criticisms and further contributes to the understanding of the politics of urban scale by asserting that "The question of scale is crucial to political geography. We do nothing without making some reference to it” (p. 21). He then questions if such politics of scale can be spatially characterized, both in content and form, in areal terms. His distinctions of the two are what he calls 'spaces of dependence’ and ‘spaces of engagement'. Spaces of dependence are defined "by those more-or-less localized social relations upon which we depend for the realization of essential interests and for which there are not substitutes elsewhere; they define placespecific conditions for our material well being and our sense of significance” (p. 2). Cox (1998) goes on to explain that these social relations construct a different form of space which he calls spaces of engagement. Spaces of engagement are defined as "the space in which the politics of securing a space of dependence unfolds” (p.2). Cox explains that the spatial aspects of the politics of space may be better conceptually understood as a network of association and that these networks "signify unevenness in the penetration of areal forms" (p.2). Therefore, a space of engagement is actually a political network that operates within the socially produced spaces of dependence.

\footnotetext{
${ }^{5}$ In Cox (1996), he provokes the question, "Scale seems to make a difference; but does it really?” (p. 669).
} 


\section{From Urban Governments to Urban Governance}

Jessup (Brenner, 1998) has argued that state space at the national level has delegated much of its prior responsibilities as a facilitator of the economy to the urban scale state. This denationalization of the state, as postulated by MacLeod and Goodwin (1999) means, “regional and local states are seen to have 'gained' an enhanced role in such governance (from the nation state), and have also begun to promote territorial and functional transnational linkages with other cities and regions, thus helping to by pass the nation state (p. 505). Therefore, an increased amount of the burden of employment and economic development has shifted from nation-state institutions to urban governments.

Harvey (2001) details another important clarifying distinction between urban 'governance' and urban 'government'. 'Government' is defined as the established bureaucracy of the state at any and all scales that emerged as a necessity of the urbanization process. 'Governance' is a combination of the state and capital's interests as a strategy which formulates the reproduction of urban space as a suitable and desirable place for capital's accumulation.

Harvey (2001) observes that the reorientation of urban governance has been symptomatic of the post-modern shift from a 'managerial' approach typical of the 1960's in which cities operated as a unit guided by the logic of rationality, to the 'entrepreneurial’ forms of action that have supplanted rationality beginning in the 1970's. This entrepreneurial approach to urban government activity shifts focus to stirring economic development and has, according to Harvey, emerged as the predominant and excepted strategy across national boundaries and even across political parties and ideologies. 
The distinction between process and object is obvious and pertinent to Harvey (2001) who suggests that urbanization is the "spatially grounded set of social processes... that produce innumerable artifacts: a built form, produced spaces and resource systems of particular qualities organized into a distinctive spatial configuration” ( p. 350). The process also creates institutional and legal forms, political and administrative systems, as well as hierarchies of power. All of these relational constructs that result from the process create a livable object known as a city in which particular cultures arise, predominantly (and historically) due to the struggle between local capital and labor. Historically because the advanced rate of globalization has made it increasingly easier for capital to transform from local dependency, relying on resources and skilled labor within a particular place, into a streaming flow of capital free to exploit labor and resources where markets demand the least amount of return. It is this macroeconomic shift that has forced the hand of local urban regimes to become less managerial and more entrepreneurial.

Urban governance has emerged as urban entrepreneurialism, of which Harvey (2001) has argued, exist four alternative strategies. These strategies identify the practices employed by many contemporary urban regimes' usage of urban planning as a tool in the production and politics of urban scales. What follows is a brief description of the four strategies.

The first of four alternative strategies for urban governance dictaits that since urban governments compete within the international division of labor, exploitation of particular local advantages for the production of goods and services must occur. Some advantages can arise from indigenous natural resources or location relative to markets. 
Others are created from public and private investment in physical and social infrastructure, which strengthen the metropolitan economic base for the exporting of goods and services. The reduction of local development costs through subsidization and of labor costs through the replacement of local collective bargaining in lieu of national collective bargaining can be powerful magnets for new economic investment.

The second alternative strategy focuses not on competitive production, but on the competitive position of spatial consumption. Tourism, retirement attractions, natural and cultural amenities, consumer attractions and the like together define a 'quality of life' attraction. The city must be attractive to new types of businesses and workers for those businesses. A city must develop as a place that is innovative, creative, and safe to live and recreate in. Thirdly, a large emphasis on the establishment and control of structural functions, such as; information, finance, decision-making, communication and transportation must be managed at the metropolitan governance level. The fourth strategy for urban governance involves the re-distribution of wealth from state or national government expenditures that serve to create a primary core investment, which then creates secondary spin-off industrial development.

\section{Conclusion}

The body of literature presented in this section provides a conceptual underpinning that is underlying throughout this research, which is that a metropolitan area, no matter how politically fragmented, is an economic whole. And as the mode of production, or economic engine, changes within this whole - other social, political and physical changes in scale occur along with the economic change. As a consequence, these changes reconstruct the spatial relationships of each of these scales, and in an 
expanding global economy it becomes increasingly difficult to distinguish one scale from another, as more and more social constructions become part of the global mode of production. 
This page left intentionally blank. 


\section{CHAPTER 3 - Planning Paradigms in Theory and Practice}

This chapter will review the debate of the paradigm shift that is present in contemporary planning theory and planning practice; a debate that is represented by the modern method of comprehensive planning represented as the rational planning model (RPM) and the postmodern critique of this model. Next will be a discussion on the privatization of planning; as planning activities increasingly shift from the responsibility of the state to for-profit professional planning firms. Following will be a discussion of the combined effects that the postmodern critique's approaches have had with this privatization, as the profession contradicts itself - and in fact creates more dysfunction by emphasizing the sustainability of the individual local unit rather than the sum of units that creates the metropolitan region - often ignoring the production and politics of scale that is endemic in economic development.

\section{Planning Theory Paradigms}

During the last 30 years, two movements have radically changed the theory and practice of land-use planning in the United States. The first movement has resulted in a debate that questions whether 'planning' has experienced a paradigm shift; is in the process of a paradigm shift; or if planning needs to move toward a paradigm shift. This debate juxtaposes two seemingly conflicting approaches to planning, each comprised with opposing epistemologies, outcomes, and purposes. This is a debate between ‘expert' (or top-down) vs. 'consensus’ (or bottom-up) planning approaches. This debate is conceptually framed as a paradigm shift from a modern to a postmodern epistemology and is theoretically contested as questioning the fundamental role of planning as 
‘planning for’ or ‘planning with’ communities (Klosterman, 1999, Hoch, 1994; Gondim, 1988; Moore, 1978).

The second movement is the privatization of land-use planning and the effects that market forces have had in producing planning geographies in the US (McCaan, 2000). Combined, these two concepts have created a complex structure that dictates where, who, why and how much land-use planning occurs. In Metropolitan Pittsburgh, this complex structure is compounded due to the vast political fragmentation that exists.

\section{Modernity (Rationality)}

'Expert' models place the planner in a role of technocrat, employing methods that are perceived as top-down and data driven. This is known as the traditional role that planners play - producing documents that are comprehensive in scope, guided by local public and private elites, and enforcing 'rational' decision making. This process is defined as the rational planning model (RPM) and originates in the scientific viewpoint that modernity popularized (Allmedinger, 2002).

In 1984, Ernest Alexander asked the poignant question, “After rationality, what?” This question asks if the traditional and comprehensive RPM is inadequate for contemporary planning practice. The RPM has been considered the dominant paradigm in US planning theory and method since it’s adoption after World War II. Rationality stands for scientific decision-making built on a foundation of truth derived from data, statistics and neo-classical economic theory. The origins of the RPM grew with the 'quantitative revolution' that had influenced the physical and social sciences, and planning seemed to teeter between both. Before the general acceptance of the RPM, planning in the US originated from the Reformist movement "at the turn of the century in 
response to the widespread dissatisfaction with the results of existing market and political processes reflected in the physical squalor and political corruption of the emerging industrial city” (Klosterman, 1985). Rationality emerged as the ‘best management practice' to address these urban ills and the focus of this rational planning, at that time, related to land-use in the city (Levy, 1990).

Planning soon became a growing enterprise. No longer was 'Planning' recruiting planners from engineering, architecture, and the like - planning had now established itself as a legitimate discipline and was now producing professional planners. Planning was no longer an activity taken up by various city departments; it had become a city department unto itself, establishing itself as a legitimate and authoritative activity. Planning had also become an academic discipline worthy of its own discourse, theory and canon of literature to be drawn upon - all legitimizing its existence and supporting its future reproduction (Howe, 1992).

What resulted has been both beneficial and destructive to planning. Rationality and its positivistic methods were adopted by practitioners, taught by educators, debated by theorists and ultimately challenged by all. The RPM offered a curtain of liability and an aura of expertise to the practitioner, a set of methods and theories to the educator and intellectual rhetoric to be supported or negated by theorists (Howe, 1992).

This institutionalization of planning and the dominant paradigm of rationality invited attack from those inside and outside of the discipline. Methods of planning practice have been criticized as unrealistic, authoritarian, paternalistic or serving capital (Wildavsky, 1973; Harvey, 1998). The legitimate existence of the planning discipline 
has been questioned and analyzed (Brooks, 1988; Hoch, 1994) and theoretically, planning has been criticized for its epistemological underpinnings (Escobar, 1992).

Planning has brought much of this criticism on itself. It has tried to do too much too fast. Progressive practitioners soon left physical land-use planning to the traditionalists and moved into social planning, where advocacy for the low-end of the public interest spectrum took precedence (Krumholz, 1982). Planning’s reactive policies oriented toward the spatiality of the physical environment became less important to proactive policies of the cultural environment where 'justice' now served as planning's predominant role. Planning schools de-emphasized design and new faculty entered from the social sciences while the founding faculty of the design school exited (Levy, 1992).

Proponents of the RPM have argued that the technical aspect of plans and the planning process "is but one factor in a network of relationships which are essentially political but not, therefore, irrational” (Alexander, 1984, p. 140). In the years since the Second World War, the role of planning has expanded beyond that of reform. Levy (1992, p. 81) alludes to the planner as "part of the administrative apparatus of land development and a facilitator of community economic development”

Critics of this modern process advocate for a more bottom-up and collaborative method that incorporates the many voices of the many publics of a place's citizenry that focuses on short range goals intended to better the quality of life for communities affected by micro, meso and macro economic processes (Dalton, 1986; Dear, 1986). Klosterman (1978) reminds us of planning's reformist origins in contradiction to the rationalist tradition that formed in the 1950's, arguing that planners can combine their dual commitments of reform and science as long as they understand the balance of 
planning for the means as well as the ends. However, this post-modern turn in planning theory has proved difficult to implement in practice. It is impossible to fully address the input of a diverse local public. Therefore, a planner must advocate for the causes and goals that she or he feels best represents the 'public interest' (Klosterman, 1999).

\section{(Post) Modernity}

The postmodern paradigm is in actuality an epistemological turn from the rational paradigm. The praxis of postmodernism's skepticism and rationality's empiricism is difficult to pin-point. Postmodernism challenges rational science's 'way of knowing' which reflects largely of the greater divide between Asian ('eastern') and European ('western') thought. "Postmodernism argues for a more de-centered view that we can never represent reality and instead must accept a never-ending chain of signifiers” (Allmendinger, 2002, p20), yet the western world since modernity has "been reduced to one form of reasoning that excludes all others.

The postmodern paradigm critiques the modern paradigm for its reliance on 'rationality' as the primary and central decision making logic. This logic manifested itself as the 'rational planning model' (RPM) - a model that has shaped the planning profession and land-use patterns of the US for the greater part of the $20^{\text {th }}$ century. While not offering an alternative to rationality and the rational planning model itself, postmodernism has, by establishing a critical discourse, attempted to curtail the positivistic nature of rationality. Postmodern planning urges the decentralization of the decision making process utilizing communication, collaboration, and by measuring success with much more narrowly focused, incremental goals as opposed to the technocratic, paternalistic long-range and comprehensiveness associated with the RPM. 
Wildavsky (1973) recognized the turmoil planning was headed into early on when he stated, "If planning is everything, maybe it’s nothing" (p. 127). He criticized the idea of national planning on the grounds that efforts to that point have never achieved the successes that planning had prescribed. The criticism attacked conventional Planning from multiple angles, suggesting that planners had either become to political - or not political enough, and that Planning should concentrate on the particular economic relationships at hand while ignoring the macro-economy as a whole. To Wildavsky, planning is an act of 'secular faith' and concluded that planning is fooling itself if it thinks it can create the future from empirically interpreting the past. If planning were truly rational, Wildavsky suggests, then plans would never fail because, "It cannot be rational to fail” (p. 153).

Klosterman (1978) revisits the reformist foundation that US planning was built upon at the turn of the $20^{\text {th }}$ century as opposed to the rationalist tradition that took hold as the dominant paradigm by 1950. Klosterman attempts to synthesize Planning's commitment to change, and it’s claim to science by discussing the philosophical conceptions of these foundations in order to arrive at common ground. Klosterman documents the epistemological train between the logical-positivist conception of ethics and the means-end conception of rationality. Klosterman ends optimistically, arguing that planners can combine their dual commitments to reform and science as long as they understated the balance of planning for the means (rationality) as well as the ends (reform).

Robert Beauregard (1991) takes planning’s dilemma and makes links with critical social theory by asserting that "Planning is currently suspended between a modernist 
sensibility whose validity is problematic and a postmodern reality posing serious challenge to planning's underlying assumptions" (p. 189), and argues that "resolving this ambivalence is essential to making planning effective” (p. 192) Beauregard concludes that if planning is to forge the 'postmodern abyss', then it must share postmodernism's assertion that an increased reliance on scientific knowledge does not set direction, but only reveals difference. What is important to the postmodernist, therefore, "is not causality... but meaning” (p. 193).

Beauragard (1989) suggests that planning as a modern project is inextricably linked to the rise of capitalism, the middle class, scientific legitimization, spatially efficient cities and an interventionist state. This foundation of a totalizing vision, however, has been 'undermined' as Planning began to be less about reform as it "sacrifices regulation and the welfare state to the lure of new investment and jobs" (p. 387). This departure is the suspension of Planning between modernity and postmodernity and Beauregard offers three paths of action for planners to resolve this divide. They are for Planning to revisit and refocus its work on the process inherent to the builtenvironment, to establish itself as a mediator between capital, labor and the state, and to advocate the meaning and consequences of urban development for all.

Michael Dear (1986) contributes to the critique first by attempting to define the indefinable meaning of postmodernism as it applies to planning with three notions of postmodernism: as style, as method and as epoch. The second contribution is that Dear applies postmodern rhetoric by deconstructing planning history in the post WW II US, which reveals the 'pastiche', or borrowed patchwork, of postmodern planning. Dear's 
reconstruction provides a discourse, which suggests three dimensions for planning to be conscious of:

- Function- context: to be aware of what planning does (function) in light of its socially constructed setting (context).

- Commodification- noncommodification: to understand the implication of planning as a product for capitalist manipulation.

- Penetration- participation: to weigh the political power infused in planning and not to let state penetration forgo public participation.

Responding to the postmodern critique, Harper and Stein (1995) claim that most of the challenges of postmodernism are valid, particularly the critique of modernism's narrow understanding of knowledge. Harper and Stein counter many of the critique’s rejections as potentially dangerous to its intent and that any attempt at a complete postmodern 'way of knowing' is impossible because it retains many of the dualisms it supposedly rejects. Harper and Stein conclude that both modernism and postmodernism are insightful and valid although "they will not always agree with them” (p. 242). The complete consensus and representation of voices is as problematic and dangerous as rational representations of science. Planning, therefore, must meet somewhere between these two and that the best way to forge 'the abyss' is with open dialogue, communication and critique of each in an open and understanding forum.

Innes and Booher (1999a; 1999b) further document the differences in the paradigms by identifying the paradoxes that arise when attempting to identify success between the RPM and the Collaborative methods. Innes and Booher claim that decisive action, achievement of goals, and implementation - all components of the RPM - are not only impossible to measure when applying the Collaborative method, but that these 
components are irrelevant because process and outcomes cannot be separated and are therefore blurred, making a never-ending dynamic in which ultimately everything is considered yet nothing is achieved.

\section{Planning Practice Paradigms}

Throughout the 1990's, collaborative (or communicative) planning has become a hegemonic concept in planning theory and practice (Tewder-Jones and Allmindinger, 1998). This focus has reoriented the planning debate on language, modes of communication, and power. These issues have been philosophically forged by Jürgen Habermas's call for a discoursive ethic and Michel Foucault's thesis of the omnipresence of discoursive power (Pløger, 2001). While the planning profession has embraced the Habermas collaborative model as inclusionary and consensus-based (Innes, 1999a, 1999b), a critical backlash has emerged following Foucault. The critique has condemned public participation as ‘an art of governance’ (Pløger, 2001) and practiced collaborative techniques, such as 'visioning', as power-grabs by local elites in effort to dictate the planning process (McCann, 2001).

\section{The Dilemma of Sustainable Development}

The prevailing practice that has resulted from the post-modern paradigm is collaborative planning (a notion that involves inclusiveness and consensus). The prevailing goal of this paradigm - both in practice and in theory - has emerged as the maxim of 'sustainability' and 'sustainable development'. Sustainable development has been broadly defined as, “...development that meets the needs of the present without compromising the ability of future generations to meet their own needs” (World Commission on Economic Development, 1987, as noted in Alshuwaikhat and Nkwenti 
(2002), and more precisely defined as, “...a dynamic process in which communities anticipate and accommodate the needs of current and future generations in ways that reproduce and balance local social, economic, and ecological systems, and link local actions to global concerns” (Berke and Manta, 1999, as noted in Alshuwaikhat and Nkwenti (2002). A globalization perspective may view these definitions as advocating for 'planning for the global market place'. Sustainable development differs from sustainability, in which human impacts on resources and the environment are constrained to protect life-support systems (Bowers, 1997 in Grainger, 1999) but without directly balancing them against the benefits of development” (Grainger, 1999, p. 252).

The notion that all places can experience simultaneous sustainable development is not possible; as the theories of urbanization and uneven development have showed us. As Grainger points out, "Because of uneven development the same degree of sustainability should not be expected at the same time for all spatial units and the same spatial level” (p. 251) (also see chapter two). This is a problem for both collaborative planning theory and the incremental planning practice. This is because the post-modern paradigm has evolved to be increasingly place-independent, meaning that space has been replaced by theoretical process and scale has been ignored in practice. Note that the broad definition of sustainable development above refers only to temporal scales (the present and the future), and that the precise definition identifies only independent local and global scales with disregard for relational local scale. Scale is inherently relative and if discussed independently of other scales, is therefore irrelevant (Jessup, in Brenner, 1997). Scale, as relation or extent, should be at the forefront of any progressive planning activity that is truly interested in achieving (near) sustainable development. The lack of 
concern of scale (as relation) is prevalent throughout much of the canons of land-use planning literature. Planning is unique among professions, as it does not require those who practice planning to share a common educational background, therefore many planners bring their own conceptual and methodological dogma from their respected disciplines; thus creating the potential for contradiction in both theory and practice.

As populations become increasingly urban, those populations are then also increasingly dependent on the labor of others within the city they dwell in. To plan locally for global markets may benefit those communities that have found a successful niche to do so, however at the same time it can be irresponsible for those successful communities not to adhere to a larger, regional and comprehensive effort aimed at the economic success and longevity of the larger urban system in which they are inevitably a part of.

Sustainable development is not an attainable goal for all places independently, as uneven development theory informs us, however it should still be a goal that is set and strived for regionally. To facilitate actions toward that goal, places in metropolitan areas are to be intentionally under-developed. Again, Grainger (1999) points out, "Capital conversion processes influencing the sustainability of development of spatial units are constrained by processes at different levels, e.g. those imposing environmental conditions on development or affecting availability of investment capital” (p. 251). While natural and political variations in places have great influence over the economic health of localities, policy is a leveraging tool to be used by local states in the struggle with private capital. Land-use policies adopted by local states can either counter or embrace market 
forces and these "(m)echanisms exist to compensate for the unevenness in development between spatial units” (Grainger, p 255).

This under-development is not only necessary, but when planned for in a regional effort, can serve to be places of both production and consumption; providing urban landscapes that are not produced uniformly but elicit varying forms necessary for continued reproduction. Such places can be desired destinations for a city's current residents while being advantageous for retaining existing and attracting outside investment. The key to this successful uneven development is to manage it at the local (metropolitan) level and not to be subject to the whims of global markets. Essentially it means dropping out of 'the race to the bottom' and challenging a city's leadership to 'aspire to the top' in order to attract the educated and professional labor pool that the global market will seek out.

\section{Planning for Profit: The Privatization of Planning}

The privatization of goods and services in urban environments is a growing trend in both developed and developing countries as the world-space economy increases in magnitude yet decreases in local control and decision-making. Planning is no exception, as for-profit planning and architecture firms now undertake an increasing amount of planning activities. In other words, the collaborative and incremental paradigm shift has benefited 'Planning' as an industry, but at what societal cost?

Throughout the 1990's, the primary concern of urban policy for most western cities was urban regeneration (Harvey, 1998). The changing societal structure from industrialization, deindustrialization, and into what is anticipated to be a service economy, also brought a shift in urban policy from what was managing city growth more 
towards dealing with the consequences of economic restructuring. This entrepreneurial role of urban regimes has been identified as the New Urban Politics (NUP) by Cox (1993). Cox defines the NUP as a process which subordinates urban regime functions to the imperatives of globalized capital accumulation. This process requires urban governments to increase the urban system's competitive advantage by restructuring the built-environment more for the needs of capital and less for the needs of the citizenry (Rodriguez, 2001).

Furthermore, urban regimes now find themselves in new roles (especially those regimes that govern post-industrial cities) that require formulating strategic imperatives that promote their city as a better business climate then a neighboring city. This type of urban and civic boosterism is reminiscent of the $18^{\text {th }}$ century's urban boosterism during the industrialization of American cities. And like the $18^{\text {th }}$ century, the political might of private capital has forced the hand of urban governments to rely on the private sector for many of the functions that urban governments can either not afford or do not have the authority to conduct. Therefore, a critical component of the NUP has been a shift from urban government to governance (Rodriguez, 2001).

Governance, in this instance, is defined not as the act of governing or being governed, but has a much deeper meaning that reflects the privatization of governing. This definition of governance is applicable at all scales and, in the case of Pittsburgh, is contradictory to the municipal fragmentation that exists which confronts directly with those localities that are trying to attain 'sustainable development'. In fact, changes in the urban economy do not take place homogeneously inside the metropolitan area. According to Rodriguez, "On the contrary, processes of socio-economic restructuring 
occur along the lines of existing social and functional divisions of space” (Rodriguez et al, p. 163).

\section{Planning as a Product}

Dear (1986) contends that the current (post-modern) planning practice has been stratified into two distinct practices that are synonymous in name only and not in their respective goals. Governments at all scales have increasingly relegated increased proportions of their planning efforts (whether willingly or due to fiscal constraints) to the private sector. Many elements of planning continue to be conducted as a function of the state. However, the degree unto which planning practice continues as a function of government is spatially uneven both among and within cities. As planning as a government action declines unevenly, planning practice as a product of private capital is inversely increasing unevenly.

Dear (1986) explains this privatization as a result of two things, what he describes as within the state's planning apparatus and through the creation of a private planning apparatus. The decline of planning as a state function is attributed to the restructuring of urbanization at the advent of the post-modern period ${ }^{6}$. This restructuring diminished the authority of public planning by way of cutting the funds available to state planning agencies to the point where many such entities ceased to exist.

Despite these cuts, the need for 'planning' increased as governments required municipal structures to undertake planning efforts in order to receive any of the already reduced federal funds available to them. It was this re-orientation of 'planning practice' that marked a fundamental shift from planning as a dynamic and continuing process into

\footnotetext{
${ }^{6}$ Harvey has marked this starting point as 1972 when President Richard Nixon declared the urban crisis to be over and cut federal funds for urban programs (2001, p.347).
} 
a practice that involved projects, tasks, endpoints and outcomes. Dear (1986) calls this shift ‘commodification’ (p. 126). Commodification of planning refers to the transformation of routine government functions into packageable units that can then be marketed and sold as a private product. The privatization approach to supplying goods and services is not novel to planning - as many urban necessities such as transportation to trash collection have faced the same transformation - however, the planning of the builtenvironment is not something that is easily commodified and such a transformation hands-off the future of a city from the local government to the market whims of corporate governance.

The ideology of planning can be explained through a number of discourses. Continuing with Dear’s (1986) deconstruction, he identifies three distinct discourses that have emerged in planning as the planning practice continues to struggle with its identity in an advanced capitalist society. The first discoursive rhetoric is a rhetoric of instrumentalism in which the planning discipline is seeking to reassert its authority and need in what Dear calls 'an obsolete professionalism'. This discourse contends that planning is a profession in which experts should lead the process as an agent of 'the public interest' and that comprehensiveness is a critical approach. The second discourse is a rhetoric of rhetorics that focuses on persuasion strategies, such as ‘collaboration' and ‘consensus’ approaches, which have gained popularity among the private planning apparatus due exactly to the rhetorical promise of inclusiveness. And a third discourse of a rhetoric of performance that is also popular among the private planning apparatus, as it seeks to legitimize and judge planning primarily as a function of a small duration or to what extent it promotes a clients interests. 
These discourses are somewhat chronologic in current practice, although the degree to which rhetoric is adopted and promoted is inherently linked to the spatially uneven shift from government to governance that occurs within a particular urban center.

The increasing privatization and commodification of planning, what Dear calls a 'mutant form of practice' is now the process that shapes the form and function of our current built environment. The implications of this mutation can be debated. This paper argues that the privatization of planning has resulted in the loss of planning's reformist origins and that privatization has resulted in Capital's cooption of the planning process in order to facilitate continued accumulation. This reorientation assimilates Planning into the circuit of production and consumption as part of Capital's organization process.

\section{Contemporary Trends}

The contemporary Pittsburgh case study has a private conglomerate of influential organizations that are steering the metropolitan region. The Allegheny Conference on Community Development (ACCD) has a long history of shaping the Pittsburgh region (see Chapter 4). The ACCD and its affiliates; the Pittsburgh Regional Alliance, the Greater Pittsburgh Chamber of Commerce, and the Pennsylvania Economy LeagueWestern Division, all promote "working in collaboration to stimulate growth in southwestern Pennsylvania’s economy and improve its quality of life” (Allegheny Conference on Community Development, 2005). The Pennsylvania Economy League (PEL) promotes the 'region' concept in slogan of sorts (Figure 2, below) with the saying "The Region Is a Product”, displaying the 10-county metropolitan area in the cover of what looks to be a box similar to a software package. Despite the implication of this campaign, it is a powerful reminder that the private sector, unrestricted by local politics 
and empowered by the market economy, is more powerful and successful at planning Pittsburgh's future than any of the over 500 metropolitan, county, or local municipal governments can achieve through Pennsylvania’s fragmented government composition.

Figure 2 - "The Region Is a Product”

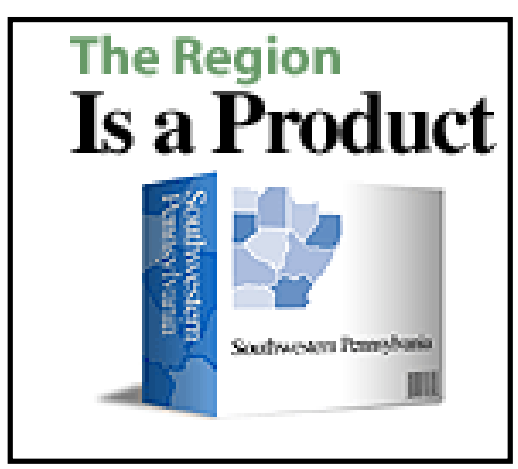

Source: http://www.pelwest.org/ 
This page left intentionally blank. 


\section{CHAPTER 4 - Historical Background}

Paul Kellogg's (1909) attempt to describe Pittsburgh and its area of influence surrounding the industrial heart of the city truly defines the spirited nature and result of the passing of the mercantile epoch and the maturing of industrial capitalism in the $20^{\text {th }}$ century for a loosely defined Pittsburgh region.

"Pipe lines that carry oil and gas, waterways that float an acreage of coal barges, four track rails worn bright with weighty ore cars, wires surcharged with a ruthless voltage or delicately sensitive speech and codes, bind here a district of vast natural resources into one organic whole",

Pittsburgh's industrial complex explored and consumed the resources it needed to facilitate its capital accumulation early in its entering of the second industrial revolution. While this economic engine grew into the $20^{\text {th }}$ century, Pittsburgh's struggle for some type of metropolitan control - be it civic government or private governance - grew too. The struggle has been complicated by many factors, most notably the political fragmentation of 'Penn's Woods', the region's narrow economic base, and the influence of industrial magnates. For urban centers to be successful in the globalized economy of the $21^{\text {st }}$ century, however, 'permanent centers of decision and action’ must be established (Lefebvre, 1991).

The history of this struggle to establish 'permanent centers of decision and action' is reviewed in this chapter. The following historical narrative utilizes the conceptual underpinning discussed in Chapters 2 and 3 as it documents the actions of Pittsburgh's public and private elite's in establishing control of what we now know as the Pittsburgh Metropolitan Region.

\footnotetext{
${ }^{7}$ Quoted from Muller, 1996, p. 72, in The Pittsburgh Survey.
} 


\section{Planning History of Pittsburgh}

Historically, the planning legacy in Pennsylvania has always been a fragmented one. William Penn founded Philadelphia (and 'Penn's Woods') during the mercantile era, premised on de-centralized, local governments forged together to create a commonwealth. In July, 1681, William Penn published his colonization plan for Pennsylvania, which started with Philadelphia. Penn’s plan was a structured landscape organized to foster Quaker values but also to accommodate economic exchange (Fries, 1977). The grid pattern that Penn devised for private parcels of land in Philadelphia (Figure 3) stated that the streets had to be uniform to the river, with houses built upon a line. This was in contradiction to the metes and bounds method of municipal property land division that was dominant throughout Pennsylvania. Metes and bounds deeds often referred to landscape features such as trees and rock outcrops, relative property ownership, and nonstandard measuring units. This contradiction spread throughout the Commonwealth, creating a mixture of state and private space being marked in both absolute and relative terms.

Penn’s physical design of Philadelphia was somewhat revolutionary at the time, but the civic planning of urban environments and the city planning movement in the US truly began at the end of the $19^{\text {th }}$ century, inspired by the Chicago World's Fair Columbian Exposition of 1892/3 (Cullingworth, 1997). As the reform movement

emerged, industrial cities of the early $20^{\text {th }}$ centuries engaged in efforts to centralize decision-making (Hays, 1989, 2000). Pittsburgh’s first successful centralization campaign was directed at controlling the floodwaters of the Allegheny and Monongahela rivers. Starting in 1908, this movement involved public and private agents at local, state 
and national scales, eventually resulting in the construction of 16 regional dams and 42 additional local flood control projects, affecting millions of acres of land in four states within the rivers' drainage basin (Smith, 1975, 1977). This transformation of the physical landscape protected the central business district, allowing for the continued growth and expansion of industry along the banks of the Allegheny, Monongahela and Ohio Rivers (Muller, 2001).

Figure 3- William Penn's Philadelphia Plan

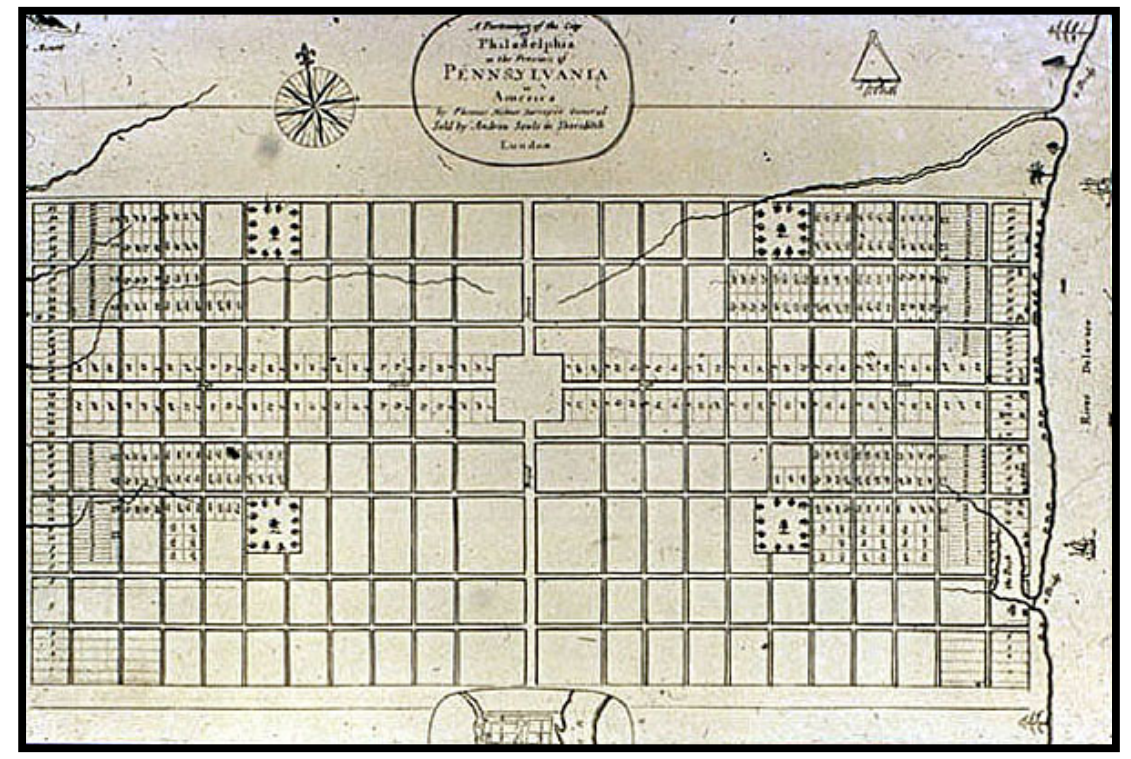

Source: http://www.brynmawr.edu/Acads/Cities/imgb/imgb3/018a.jpg

Zoning ordinances emerged in Pittsburgh in 1923 as a way to regulate how real estate would be used and who would use it (Daly, 1988). In contrast to the flood control campaign, which essentially implemented regulation on one large land mass (the headwaters of the Ohio River), zoning legislation allowed local governments to regulate land-use on the small parcels of private property owners.

Between 1908 and 1923, a number of additional policies aimed at political centralization were adopted such as building and tax codes, municipal bureaucracies, city 
charter revisions and annexation (Daly, 1988). Industry and government leaders competed for control of the 'Pittsburgh industrial district' starting in the late 1800's and there was competition amongst public efforts ${ }^{8}$ and private efforts for control ${ }^{9}$. This public and private competition has lead to the public-private partnerships that continue to shape Pittsburgh’s economic landscape (Lubove, 1995, 1996; Stewman and Tarr, 1982). Prominent urban architects and politicians of the early $20^{\text {th }}$ century agreed that a single apparatus should govern the Pittsburgh industrial 'district' ${ }^{10}$. This local-regional struggle is a process that is still prominent today.

Community and municipal land-use planning policies stem from the federal Housing Act of 1954, specifically Section 701, which created a grant program for communities to pay for comprehensive plans and land-use regulations. Most local municipal planning in Pennsylvania is due to this program. As federal funding of local planning ended, Pennsylvania created its own State Planning Assistance Grant Program. Due to these programs, nearly two-thirds of Pennsylvania’s municipalities and counties engage in land-use planning to some degree (Center for Rural Pennsylvania, 2002).

\footnotetext{
${ }^{8}$ Olmsted, F. L., 1911, Pittsburgh Main Thoroughfares and the Down Town District, improvements necessary to meet the citys present and future needs, a report. Pittsburgh: Pittsburgh Civic Commission.

${ }^{9}$ Citizens Committee on City Plan, 1923. The Pittsburgh Plan.

${ }^{10}$ Olmsted wrote in 'Thoroughfares...' that "The simplest and most logical procedure, if the boundaries of the city and of the boroughs are to remain substantially unchanged, would be to establish a common agency for dealing with the general problems of city planning for all of the municipalities and the related parts of the country outside of them...”. In 1911, Mayor William F. Magee proposed a consolidation bill that would have annexed and additional 24 square miles and 227,000 people to the City of Pittsburgh, calling this area the "real Pittsburgh" (Daly, p. 109).
} 


\section{Urban Decentralization}

There is a large literature about the suburbanization of North American cities in both urban history and urban geography that has focused on the movement of city residents away from the CBD to the newly developed areas outside of the city due to availability of cheap land, inexpensive building methods, and rapid transportation. ${ }^{11}$ These studies have argued that North American cities did not experience decentralization until the post-war period starting in 1945, attributing much of the flight to new housing policy and a booming economy, while a minority of others have argued that the decentralization of the production process in most of North America's traditional industrial core was a result of class struggle (Gordon, 1975).

Walker and Lewis (2001) re-visited the decentralization question arguing that industrial suburbanization has been an ongoing process since industrializations second wave starting in 1850. Their interpretation goes against the traditional wisdom that suburbanization began nearly 100 years later.

This new interpretation combines three concepts to support the argument. First, is 'geographic industrialization, ${ }^{, 12}$, in which new industry locations are created from old ones which can spur secondary and ancillary industries that may, or may not, attract new labor forces. Geographic industrialization differs from traditional location and mainstream economic theory which suggest that producers are assumed to minimize their total costs, including transportation costs, so the optimal location that a firm will consider depends on distances to raw materials and the final market. Industrial location patterns are created through a process of growth rather than a process of efficient allocation of

\footnotetext{
${ }^{11}$ See Kenneth T. Jackson’s Crabgrass Frontier, 1987.

12 Attributed to Storper and Walker's, The Capitalist Imperative, 1989.
} 
plants and that industry location and regional growth are produced rather than dictated by the placement of resources and consumers. Second, investments in real estate expand the urban proper, producing more space for the city's primary role - to accumulate capital for the industrialists it serves. Third, political guidance by business and government leaders encouraged the out migration of manufacturing industrial processes from the CBD into the hinterland while at the same time attempting to redevelop the CBD for managerial industrial processes.

Industry, as well as the local government and local labor markets of the $19^{\text {th }}$ century and the first half of the $20^{\text {th }}$ century were truly 'locally dependent' on the city to continue their own reproduction (Cox and Mair, 1988). Business and government leaders strived for control of the 'Pittsburgh industrial district' starting in the late 1800's. Early on there was more competition amongst public efforts ${ }^{13}$ and private efforts ${ }^{14}$. However, it soon became evident that the public and the private needed each other to achieve their individual goal. But, as Stewman and Tarr (1982) begin their piece, "Although the roots of public-private partnership in Pittsburgh lie in the nineteenth century, the earliest plans issued both by the private sector and by the public-private groups were not always carried out to fruition” (p.59).

These theoretical perspectives and conceptual framework will structure the following narrative analysis of Pittsburgh's $20^{\text {th }}$ century planning history.

\footnotetext{
${ }^{13}$ Olmsted, F. L., 1911, Pittsburgh Main Thoroughfares and the Down Town District, improvements necessary to meet the citys present and future needs, a report. Pittsburgh: Pittsburgh Civic Commission. ${ }^{14}$ Citizens Committee on City Plan, 1923. Parks- A Part of the Pittsburgh Plan, Report No. 4 Pittsburgh.
} 


\section{Geographic Industrialization}

Walker and Lewis (2001) claim that, "Industry does not locate in a city, it helps create the city” (p. 7). The urbanization process of the Pittsburgh landscape is estimated to have started somewhere around 1790 (Harper, 1988). This urbanization moved rapidly between the years 1870 to 1890 as the number of people gainfully employed as a result of the rise of manufacturing industries went from under 65,000 to nearly 200,000 (MacLaughlin, 1938). By the $20^{\text {th }}$ century, Pittsburgh’s economy was already facing decline but the economic base of the city continued to be reliant on the original industries of iron, steel, rail and glass through the mid-century. While studies of the time warned of Pittsburgh's continued dependency on these no-growth industries, the industrial geography continued to be reproduced by the industrial leaders of 'the district'.

In Pittsburgh's case, defining this metropolis has been a 'muddled' task, at best (Muller, 1996). Kellogg (1909) and the other authors of the Pittsburgh Survey never truly defined the spatial limits of 'the district', only referring to its industrial geography as an 'organic' city in which the separate parts made the whole. Industrial investment and disinvestments have historically created patterns of uneven urban development, where some areas grow while others decline (Smith, 1990). This urban development is illustrated by Walker and Lewis (2001);

"As cities have grown, layer upon layer of suburban development has been added to the built-up area, leaving former outlying districts well inside the metropolis and often erasing historic patterns of expansion by dispersion in the process" (p. 7).

The Pittsburgh business elite made great strides in producing and protecting the industrial district as well. Reformist volunteer groups began to inevitably address the deteriorating environmental conditions of the downtown that was a result of heavy 
manufacturing. These reforms initially focused on air quality and flood control. Many private groups formed to centralize decision making within the district, which was seen as the only way to address these paramount concerns. This would also benefit the business interests of those making these decisions. Groups such as the Citizens Committee on City Plan, the Chamber of Commerce, the Civic Club and the Allegheny County Planning Commission formed in private circles to establish and stabilize control (environmentally, politically and economically) over the industrial geography of Pittsburgh. Two groups in particular, The Flood Commission of Pittsburgh (formed by the Chamber of Commerce) and the Citizens Committee on Flood Control enjoyed great success.

These groups were formed to address the issue of flooding of Pittsburgh's downtown and surrounding industrial and residential areas located along the riverbanks. The Flood Commission, lead by H.J Heinz, was successful in creating the system of dams and reservoirs that continue to protect the large capital investments of the downtown area today. This operation of channels and locks severely affected the landscape of rural areas for hundreds of miles, displacing an entire Native American settlement in western New York and establishing the Allegheny and Monongahela National Forests in Pennsylvania and West Virginia, respectively, for the purpose of protecting the head waters of the rivers of the same name. This success came about with the Flood Commission persuading the U. S. Army Corps of Engineers (ACE) to assume responsibility for inland flood control (a task they never assumed beforehand, prior to these developments, the ACE's primary purpose was to only to maintain navigable waters) and by also enlisting the US Forest Service to take on the replanting of denuded forestlands in the headwaters. 
These successes can be attributed, in some part, to the enlisting of George H. Maxwell as the Flood Commissions executive director. Maxwell had previously worked at the national level and his political influence and networking enabled those aiming to control flooding in and around Pittsburgh to 'jump scales' and partner with Federal agencies in their cause. The early efforts to fortify Pittsburgh's industrial geography was perhaps the first successful attempt by either private or public agents to centralize the decision making process for the Pittsburgh region (Smith, 1975, 1977; Palmer, 1986).

\section{Capital Real Estate Investments}

The industrial elite's attempt at centralization by means of organizing the region's landscape was problematic for those same business leaders who further fragmented the local land use. In 1901 the Pittsburgh elite retained Fredrick Law Olmsted, Jr. to produce estates just outside of the downtown industrial core, escaping the social turbulence and creating structured beauty in their own private worlds (Muller and Bauman, 1996; Bauman and Muller, 1997).

The city government addressed the social and environmental turmoil of the downtown by adopting zoning regulations (1923) - a practice that further spatially fragmented the landscape by designating clearly defined usages for land parcels (Daly, 1988). This reformist activity was spreading through out urban-industrial America and arguably created as many problems as it solved. Zoning further organized the industrial space while also providing a mechanism for the emerging middle and upper-middle class residents of the city to create their own private communities (Hoffman, 1992).

While reformist projects such as zoning (re)organized the land-use of Pittsburgh's industrial core (consisting primarily 3 to 4 miles up and down the three rivers from the 
point), other factors, such as labor disputes and advances in technology spurred expansion beyond this area. An organized, and somewhat militant, labor force had formed along with Pittsburgh's manufacturing industries. Strikes and violent unrest, such as those at the Apollo and Homestead Works, resulted in business owners moving their factories up and down the rivers in order to escape "this cauldron of labor politics" (Muller, 2001, p.63).

Some of the real estate investments were made by speculative developers who anticipated industrial expansion while other land grabs were carried out by the magnates themselves in order to unearth the mineral resources at some sites while other sites were left intentionally underdeveloped which served their needs by having land available for expansion, preventing other industrialists from purchasing developable land thus stifling competition, and speculating on rising real estate prices (Muller, 2001). These patterns of capital investment and (under)development further fragmented the geography into localized industrial works and a spatially divided labor force that all functioned under Pittsburgh's metropolitan economy.

\section{Public-Private Partnerships}

Private and public interests of Pittsburgh proper have struggled to gain control of greater Pittsburgh for most of the $20^{\text {th }}$ century. In 1910 it was Fredrick Law Olmsted, under the direction of The Committee on City Planning, who completed a plan for Pittsburgh's downtown district. In this plan, Olmsted claims that the need for metropolitan governance, whether public, private or a combination of both, was implicit,

"The simplest and most logical procedure, if the boundaries of the city and of the boroughs are to remain substantially unchanged, would be to establish a common agency for dealing with the general problems of city planning for all of the municipalities and the related parts of the country outside of them... If the 
difficulty should be met simply by extending the boundaries of the city, it is important that the new boundaries should not merely include those areas which are now seen to have close physical relations with the city, but a great extent of territory within which the beginnings of urban or suburban growth have started, or are likely to start, during the next generation" (Olmsted, 1911, p. 43).

Olmsted's vision of metropolitan planning is also conceptually inviting, as his understanding of the areas outside the political jurisdiction of the city have close economic relations and that there should be some attempt to organize this 'organic' industrial space into a more structured arena suitable for any and all future growth incited by the industrial core of the city.

The civic community’s vision was comprehensive, yet powerless. The city government's annexation strategy was facing opposition on many fronts, yet Mayor Magee, also in 1911, introduced a state consolidation bill to unify the "real Pittsburgh" that consisted of "sixty-five square miles of territory” (Daly, 1988, p.109). This bill failed, but Magee's continued message while in office was the need to establish some type of centralized authority of metropolitan Pittsburgh. The private sector's early attempts at organizing metropolitan Pittsburgh, such as the flood control movement, had more success in establishing the physical and industrial landscape of 'greater' Pittsburgh, but this space remained politically fragmented.

What eventually resulted, through various attempts at regional governing and governance, has been the public-private partnership as the vehicle for metropolitan planning and economic development (Stewman and Tarr, 1982). However, this publicprivate leadership has never been centralized, and each organization has developed strategies to further their own self-interest. The combined efforts of these individual 
organizations have resulted in what Ahlbrandt and Weaver (1987) consider as Pittsburgh's best and only approach to regional development. 


\section{CHAPTER 5 - Research Design}

The overall goal of this research is to analyze the relationship between local planning policy and land-use change in the Pittsburgh metropolitan region using remotely sensed imagery and to analyze this information utilizing statistical methods. The research design chapter has two sections: remote sensing analysis - change detection, and statistical analysis - logistic regression model. Each section describes the data and the methods used to conduct the analysis. The remote sensing change detection analysis involved the supervised classification of two Landsat scenes and change detection analysis of the results using an image-to-image technique. The statistical analysis used the results of the change detection and data that represented which planning tools municipalities had enacted into a logistic regression model.

Each of these steps is discussed more thoroughly in the remainder of this chapter. The remainder of this section will discuss remote sensing change detection analysis and the use of information derived from remotely sensed data with other secondary sources in urban land-use analysis. Following this section each step of the analysis will be discussed in more detail.

\section{Research Objectives}

As presented in Chapter 1, the research objectives for this research are:

- Identify changes in land-use within the municipalities of the Pittsburgh region by means of remote sensing change detection analysis, and 
- Identify the relationship between local municipal planning policy tools with particular land-use changes throughout the Pittsburgh region by means of statistical analysis.

\section{Remote Sensing Analysis - Change Detection}

\section{Change Detection Analysis Background}

There are two approaches for change detection analysis (CDA) using remotely sensed imagery, (1) post-classification analysis - which involves comparative analysis of independently produced classifications for different dates, and (2) simultaneous classification analysis - which involves simultaneous analysis of multitemporal multispectral data (Singh, 1989). Several procedures using digital data exist for examining land use change detection. These methods include image differencing, image ratioing, image regression, vegetation index differencing, principal component analysis, change vector analysis and post-classification comparison (Jensen, 1981; Singh, 1989; Mouat, 1993).

The CDA procedure employed for this research will be a post-classification analysis using the Matrix function in the Erdas Imagine package. Post-classification analysis is the most obvious method of change detection. This method involve supervised categorical classifications of both images using training sites for each of the land-use classes analyzed. Due to the independent categorical classification process of each of the images, radiometric normalization is not necessary. Like all CDA methods, post-classification analysis has advantages and disadvantages. The advantages include; the ability to produce change-maps that show a complete matrix of changes, not needing 
to normalize for atmospheric and sensor differences between the two data sets, and reducing the problem of highly-accurate registration of multidate images.

The major disadvantage of the post-classification method is the possibility of producing a large number of erroneous change indicators since an error on either date gives a false indication of change (Singh, 1989). An example of the error possibility is offered by Singh, "two images classified with 80 percent accuracy might have only a 0.80 x 0.80 x $100=64$ percent correct joint classification rate” (p. 996). Jensen (1981) advises that due to the difficulty in classifying urban land-use with Landsat TM data, extreme care must be exercised when applying classification comparisons. Jensen reports that the heterogeneity of suburban land use produced many 'mixed' pixels and that too much change was consistently identified (i.e., errors of commission).

\section{Analyzing Remote Sensing Information with Secondary Data}

The use of remote sensing data with other secondary or ancillary data has been the subject of many facets of urban analysis. Some examples include the planning for urban infrastructure (Jensen, and Cowen, 1999; Kawamura, 1996; Jensen, et al., 1994), change detection analysis with corresponding socio-economic/census data (Masek, et al., 2000; Ryznar and Wagner, 2001), population estimations (Lindgren, 1985; Lo, 1995; Webster, 1996; Haack et al., 1997) and quality of life indices (Webster and Hirsch, 1992; Lo, 1997a, 1997b).

In regards to land-use change and zoning, Croissant and Monroe (2003) used Landsat TM data to analyze the relationship between landscape fragmentation and zoning policy at the parcel level. Using several methods of detecting and assessing land-use 
change, the authors found that the slope and size of parcels affected fragmentation, but that zoning was the most significant factor.

Zhoa, et al., (2003) also utilized Landsat TM data to analyze the impact of urban planning on land-use and land cover. Assessing the relationship between land-use in Pudong of Shanghai, China and each of it's functional zones ${ }^{15}$, the authors found that the type and pattern of change of land-use / land cover were quite different among the seven functional zones.

\section{Remote Sensing Data}

This research used two temporally distinct remotely sensed Landsat scenes. Landsat TM data has been found to be useful and effective when evaluating large areas such as metropolitan areas (Toll, 1985; Khorram, et al., 1987; Vogelmann, et al., 1998; Jensen and Cowen, 1999) and it has been found to be particularly useful when estimating land cover change across large metropolitan areas (Jensen, 1981; Fung, 1990; Masek, et al., 2000; Ryznar and Wagner, 2001; Xiuwan, 2002).

The entire study area is within the Landsat scene Path 17, Row 32 (17/32). Both scenes were downloaded from the World Wide Web from the West Virginia View website (www.wvview.org). The first scene was captured on 10/02/1992 by the Thematic Mapper (TM) instrument onboard the Landsat 5 satellite measuring 7 multispectral bands. The second scene was captured on 10/06/2002 by the Enhanced Thematic Mapper Plus (ETM+) instrument onboard the Landsat 7 satellite measuring 7 multispectral bands and 1 panchromatic band.

\footnotetext{
15 'Functional Zones' in Shanghai define what type of economic activity is permitted to take place in certain areas (i.e., export processing, finance, free trade, industrial, agricultural, etc.).
} 
Both scenes were processed by the USGS / EROS Data Center using the Landsat processing system called the National Landsat Archive Production System (NLAPS). The 1992 Landsat scene was processed on 06/01/2004 and the 2002 Landsat scene was processed on 02/04/2004. Both scenes were Precision Geocorrected using a 4-point cubic convolution resampling method and then projected to the Universal Transverse Mercator (UTM) projection, zone 17 and the WGS84 horizontal datum (USGS, 2005).

\section{Software}

Several software packages were used in this research. Erdas Imagine was used to perform the supervised classification, matrix function, error assessment, summary report and display. ArcGIS 9.0 and ArcView 3.3 were used to spatially assign data by location, query and display. Microsoft Excel was also used for additional formatting, analysis and display.

\section{Supervised Classification}

Prior to conducting the CDA, a supervised classification of both Landsat scenes was performed. Supervised training requires a priori knowledge of the study area and what kind of information is desired from the processing, such as the classes to be identified. Training sites are selected through out the scene for each of the classes to be identified. In this instance, a minimum of 10 training sites were chosen per class in order to capture a representative spectral signature for each respective category. The supervised classification of both data sets utilized a parametric, maximum likelihood set of decision rules with the use the probabilities assigned to the signatures. The parametric rule classifies pixels that fall into the overlap region by testing the pixel against the 
overlapping signatures only. The maximum likelihood decision rule is based on the probability that a pixel belongs to a particular class. The basic equation assumes that these probabilities are equal for all classes, and that the input bands have normal distributions (Leica Geosystems, 2003).

A supervised classification is an ideal method for this research because the information needed for analysis consists of only 5 categorical classes: 1) water, 2) urban, 3) residential, 4) forest, and 5) agricultural pastures and open spaces (AgGrass). Four of these five classes were further used in the logistic regression model (\#’s 2-5). Classes’ 2urban and 3-residential and classes 4-forest and 5-AgGrass were also recoded into new, coarser catagorical classes, respectively, in order to represent two very general classes, 'Developed' and 'Less-developed' (Table 1).

Using only these five land-use categories was deliberate for several reasons. Since there is a large interest in evaluating the reduction of agricultural and forested lands as a result of urbanization, identifying urban and residential land-uses versus forested and agricultural pastures and open spaces captures this process. 'Urban' in this context represents commercial and industrial land-uses which include central business districts, ‘downtown’ areas, manufacturing, big-box retail locations, shopping plazas, office parks, universities, hospitals and other predominately paved and impervious areas that are devoid of vegetation. 'Residential' in this context represents the living spaces of workers and residents of the region, which includes sub-urban housing development, villages, mobile home parks and other small settlements identified by lower density housing patterns. It is understood that residential uses occur in urban areas and vice-versa. The words used to name the categories are semantic and therefore are interpretations used for 
conveying information. In essence, the ‘urban’ category represents a highly developed built-environment and the 'residential' category represents a built-environment to a lesser-degree. The distinction between the two is important, however, as clustered increases in residential areas can be an indicator of emerging urban areas.

\section{Table 1 - Land-use Categories}

\section{Single Image Classifications:}

\section{Recoded Classes:}

1. Water (identified in classification but not included in statistical analysis)

2. Urban

3. Residential

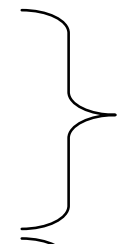

4. Forest

5. Agriculture/Grass (AgGrass)

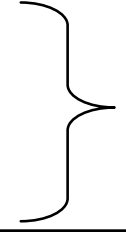

$$
\text { A = 'Developed' }
$$

B = 'Less Developed’

\section{Overlay Image Differencing (Matrix Analysis)}

The Matrix function in Erdas Imagine (Leica Geosystems, 2003) was used to determine the land-use category change from the classified 1992 scene to the classified 2002 scene. Matrix analysis produces a thematic layer that contains a separate class for every coincidence of classes in two layers.

The output classes are assigned according to the coincidence of any two input classes. The resulting class values of a matrix operation are different for each coincidence of two input class values. Since there were 5 classes in each input image, the 
number of output classes as a result of the Matrix analysis produced 25 from-to land-use classes plus 1 no change class and 1 ' 0 ' class representing data outside of the study area.

The category changes that resulted form the Matrix analysis were then assigned to each of the municipalities (polygons) with the use of a graphic model constructed in Erdas Imagine where the raster values were summarized within each polygon of the vector file that represented the municipalities. The output of this summary was a table of values of each category change per polygon (municipality). The values in this table were then used as values for the statistical analysis for objective two.

\section{Accuracy Assessment}

Accuracy assessment is a general term for comparing the classification to geographical data that are assume to be true in order to determine the accuracy of the classification process (Leica Geosystems, 2003). Conducting an accuracy assessment of a classified image requires a) a random sample of ground reference points to be used in the assessment, b) the classified image, and c) ground truth data for the reference image (captured from fieldwork or from a secondary source). As a result of the accuracy assessment, several statistics are generated in the Erdas Imagine package in order to evaluate the classification's accuracy. There is the error matrix, the accuracy totals and the KAPPA coefficients. Below is a discussion of the ground reference point selection criteria and the statistics produced in this research's accuracy assessment.

This study used the Erdas Imagine 'equalized random rule’ (Leica Geosystems, 2003) when generating the random reference points. The equalized random rule dictates that each class has an equal number of random points generated. The number of reference pixels is an important factor in determining the accuracy of the classification. It 
has been shown that more than 250 reference pixels are needed to estimate the mean accuracy of a class to within plus or minus five percent (Congalton, 1991).

A total of 256 random reference points were generated for use in each of the accuracy assessments. For each class 51 points were generated plus 1 additional point, for a total of 256 reference points [ 5 supervised classes; 50 points per class, plus $1=$ $(5 * 50)+1=256]$. The points were generated within a sub area within the study area for

which aerial photos of dates similar to the satellite imagery were available. This sub area encompassed approximately $80 \%$ of the total study area. The same reference points that were used in the 1992 error assessment were also used in the 2002 error assessment. Using the same points that were generated using the equalized random rule for the '92 assessment did not represent an equal number of random points generated per class in the '02 classification. This is logical assuming there was a significant amount of land-use change within the study area between 1992 and 2002 (See Tables 2 and 3).

The following descriptions and analysis are fully described by Congalton (1991).

\section{Error Matrix}

The error matrixes (Table 2 and 3) represent the accuracy of each category classified. This is done by expressing the number of pixels assigned to a particular category relative to the actual category which is verified from the ground; in this case it is verified using aerial photos acquired at corresponding time periods. 
Table 2 - 1992 Error Matrix

\begin{tabular}{|c|c|c|c|c|c|c|c|}
\hline \multirow[b]{2}{*}{ Category } & \multirow[b]{2}{*}{ Classified Data } & \multicolumn{5}{|c|}{ Reference Data } & \multirow[b]{2}{*}{ Row Total } \\
\hline & & Water & Urban & Residential & Forest & AgGrass & \\
\hline Water & Class 1 & 51 & 0 & 0 & 0 & 0 & 51 \\
\hline Urban & Class 2 & 6 & 29 & 5 & 1 & 10 & 51 \\
\hline Residential & Class 3 & 1 & 3 & 35 & 7 & 5 & 51 \\
\hline Forest & Class 4 & 0 & 0 & 1 & 51 & 0 & 52 \\
\hline AgGrass & Class 5 & 0 & 0 & 0 & 7 & 44 & 51 \\
\hline & Column Tota & 58 & 32 & 41 & 66 & 59 & 256 \\
\hline
\end{tabular}

Table 3 - 2002 Error Matrix

\begin{tabular}{|c|c|c|c|c|c|c|c|}
\hline & & \multicolumn{5}{|c|}{ Reference Data } & \multirow[b]{2}{*}{ Row Total } \\
\hline Category & Classified Data & Water & Urban & Residential & Forest & AgGrass & \\
\hline Water & Class 1 & 42 & 0 & 0 & 0 & 0 & 42 \\
\hline Urban & Class 2 & 10 & 18 & 1 & 0 & 0 & 29 \\
\hline Residential & Class 3 & 1 & 7 & 38 & 5 & 5 & 56 \\
\hline Forest & Class 4 & 2 & 0 & 2 & 64 & 5 & 73 \\
\hline AgGrass & Class 5 & 0 & 2 & 4 & 3 & 47 & 56 \\
\hline & Column Total & 55 & 27 & 45 & 72 & 57 & 256 \\
\hline
\end{tabular}

This error matrix is then used to determine the accuracy totals. Accuracy totals are determined for both the overall classification accuracy and for individual category accuracy (Table 2 and 3). The overall classification accuracy is determined by dividing the total amount of pixels classified correctly (the sum of the major diagonal in the error matrix) by the total number of pixels in the error matrix. Using this technique, the overall classification accuracy for the 1992 supervised classification is 82\% (Table 4) and the overall classification accuracy for the 2002 supervised classification is also 82\% (Table 5). 
Table 4 - 1992 Accuracy Totals

\begin{tabular}{|c|c|c|c|c|c|}
\hline \multicolumn{3}{|c|}{ Overall Classification Accuracy = } & \multicolumn{3}{|c|}{$2 \%$} \\
\hline Class Name & $\begin{array}{l}\text { Reference } \\
\text { Totals }\end{array}$ & $\begin{array}{c}\text { Classified } \\
\text { Totals }\end{array}$ & $\begin{array}{l}\text { Number } \\
\text { Correct }\end{array}$ & $\begin{array}{l}\text { Producers } \\
\text { Accuracy }\end{array}$ & $\begin{array}{c}\text { Users } \\
\text { Accuracy }\end{array}$ \\
\hline Water & 58 & 51 & 51 & $88 \%$ & $100 \%$ \\
\hline Urban & 32 & 51 & 29 & $91 \%$ & $57 \%$ \\
\hline Residential & 41 & 51 & 35 & $85 \%$ & $69 \%$ \\
\hline Forest & 66 & 52 & 51 & $77 \%$ & $98 \%$ \\
\hline AgGrass & 59 & 51 & 44 & $75 \%$ & $86 \%$ \\
\hline Totals & 256 & 256 & 210 & & \\
\hline
\end{tabular}

Table 5 - 2002 Accuracy Totals

Overall Classification Accuracy $=\quad 82 \%$

\begin{tabular}{|c|c|c|c|c|c|}
\hline Class Name & $\begin{array}{c}\text { Reference } \\
\text { Totals }\end{array}$ & $\begin{array}{c}\text { Classified } \\
\text { Totals }\end{array}$ & $\begin{array}{l}\text { Number } \\
\text { Correct }\end{array}$ & $\begin{array}{l}\text { Producers } \\
\text { Accuracy }\end{array}$ & $\begin{array}{c}\text { Users } \\
\text { Accuracy }\end{array}$ \\
\hline Water & 55 & 42 & 42 & $76 \%$ & $100 \%$ \\
\hline Urban & 27 & 29 & 18 & $67 \%$ & $62 \%$ \\
\hline Residential & 45 & 56 & 38 & $84 \%$ & $68 \%$ \\
\hline Forest & 72 & 73 & 64 & $89 \%$ & $88 \%$ \\
\hline AgGrass & 57 & 56 & 47 & $82 \%$ & $84 \%$ \\
\hline Totals & 256 & 256 & 209 & & \\
\hline
\end{tabular}

Accuracy Reports

Individual category accuracies can also be computed in a similar, yet more revealing, way. Unlike the overall classification accuracy technique where the total correct are divided by the total amount of pixels in the cell array, individual category accuracies can be computed to measure the probability of a reference pixel being correctly classified and can measure the probability that a classified pixel actually represents the classification in reality. These measures are called errors of omission (referred to in the table as producer's accuracy), and errors of commission (referred to in the table as user's accuracy), respectively. Errors of omission are determined by 
dividing the total number of correct pixels in a category by the total number of pixels of that category as determined form the reference data. Similarly, the measure of commission error is determined when the total number of correct pixels in a category is dived by the total number of pixels that were classified in that category.

These percentages can initially mislead an interpreter into believing there is an unrealistically high degree of accuracy in all of the categories. However, the generalized overall classification accuracy may differ greatly from individual category accuracies. For example, a discussion of the producers and users accuracy percentages from Table 4 above reveals that the producer of this information/map could have claimed in 1992 that $91 \%$ of the time an area that was identified as urban was urban, but that a user of this information/map will find that $57 \%$ of the time the actual land-use was urban when the location was visited.

The values used in Tables 4 and 5 are used to compute the overall accuracy of the change transition data that were determined as a result of the Matrix analysis. The overall accuracies from Tables 4 and 5 are multiplied together to display the change transition overall classification accuracy. Therefore, the overall classification of the change transition information is $67 \%$.

\section{KAPPA Coefficient}

The Kappa coefficient (Tables 6 and 7) is a discrete multivariate technique used in measuring the agreement of accuracy of classified data. The Kappa coefficient expresses the proportionate reduction in error generated by a classification process compared with the error of a completely random classification. For example, the Residential value of .62 in Table 6 below implies that the classification process is 
avoiding 62 percent of the errors that a completely random classification generates

(Congalton, 1991, in Leica Geosystems, 2003).

Table 6 - 1992 KAPPA Coefficients

\begin{tabular}{|l|l|}
\hline $\begin{array}{l}\text { Overall Kappa Statistics }=0.78 \\
\text { Conditional Kappa for each Category }\end{array}$ \\
\hline Class Name & Kappa \\
\hline Water & 1.00 \\
Urban & 0.51 \\
Residential & 0.63 \\
Forest & 0.97 \\
AgGrass & 0.82 \\
\hline
\end{tabular}

Table 7 - 2002 KAPPA Coefficients

Overall Kappa Statistics $=0.77$

Conditional Kappa for each Category

\begin{tabular}{|l|l|} 
Class Name & Kappa \\
\hline Water & 1.00 \\
Urban & 0.578 \\
Residential & 0.61 \\
Forest & 0.83 \\
AgGrass & 0.79 \\
\hline
\end{tabular}

\section{Statistical Analysis - Logistic Regression}

The relationship between local planning policy and land-use change in the Pittsburgh metropolitan region is examined by means of a logistic regression model. The model estimates the relationship between the change in land-use in a given municipality derived from the remote sensing change detection analysis described above and four different planning tools adopted by each individual municipality as of 2001. The planning tools used in the analysis are Comprehensive Plan, Planning Commission, Zoning, and Subdivision Regulation. The data for the planning tools were obtained from the Center for Rural Pennsylvania (2001). The comprehensive plan definition and guidelines are listed in Article III, Section 301 of the Pennsylvania Municipal Planning Code (MPC). By definition, a county and municipal comprehensive plan is a "land use and growth management plan” (Commonwealth of Pennsylvania, p. 2, 2001) prepared by 
the county planning commission, either internally or by contract, to be adopted by the county commission or municipal authority and establishes broad goals and criteria for future planning efforts. A Planning Commission or planning agency as listed in Article II, Section 201 and 202 of the MPC, can be created or abolished, by ordinance, by a governing body. A Planning Commission is also granted duties and functions, by ordinance, by the governing body. Zoning is defined in Article VI of the MCP, and the governing body of each municipality "may enact, amend and repeal zoning ordinances to implement comprehensive plans and to accomplish any of the purposes of the MPC (Commonwealth of Pennsylvania, p. 43, 2001). Subdivision regulations are defined under Article V of the MPC and allow for the governing body of each municipality the ability to "regulate subdivisions and land development within the municipality by enacting a subdivision ordinance” (Commonwealth of Pennsylvania, p. 19, 2001).

The logistic regression model also includes six control variables relating to a given municipality's population, income and the 1992 land-use profile to ensure that the estimated relationships between land-use change and the four local planning tools are independent of these basic demographic and land-use factors. The Southwestern Pennsylvania Commission (SPC) provided a vector file of the local municipal boundaries and census data within the study area. The population and income data were obtained from the US Census of Population (2004) and the 1992 land-use profile data were obtained from the change detection analysis. 
The logistic model is defined as follows:

$$
\begin{aligned}
\operatorname{logit}(\mathrm{p}) & =\log [\mathrm{p} /(1-\mathrm{p})]=\alpha+\beta_{1} \text { COMP }+\beta_{2} \text { ZONE }+\beta_{3} \text { SUB }+\beta_{4} \text { COMM } \\
+ & \beta_{5} \text { LANDUSE92 }+\beta_{6} \text { AVPOP }+\beta_{7} \text { POPCHANGE }+\beta_{8} \text { AVINC } \\
& +\beta_{9} \text { INCCHANGE }+\beta_{10} \text { AVDENSITY }+\mathrm{e}
\end{aligned}
$$

where:

- $\mathrm{p}$ is the percent change from one land-use to another

- COMP is a binary variable indicating whether a municipality has a comprehensive plan or not

- ZONE is a binary variable indicating whether a municipality has a zoning ordinance or not

- SUB is a binary variable indicating whether a municipality has a subdivision ordinance or not

- $\mathrm{COMM}$ is a binary variable indicating whether a municipality has a comprehensive plan or not

- LANDUSE92 is the proportion of the municipality covered by the original landuse in 1992

- $\quad$ AVPOP is the average size of the population in the municipality between 1992 and 2002

- POPCHANGE is the percent change in the size of the population in the municipality from 1992 to 2002

- AVINC is the average household income in the municipality between 1992 and 2002

- INCCHANGE is the percent change in household income in the municipality from 1992 to 2002

- AVDENSITY is the average population density in the municipality between 1992 and 2002

- $\quad \alpha$ and $\beta_{1}-\beta_{10}$ are parameters to be estimated and e is an error term. 
The logistic regression model was used in this research rather than the standard ordinary least squares (OLS) estimation procedure because the land-use change dependent variable is expressed as a percentage. OLS is incapable of restricting the predicted values of the dependent variable to range between zero and one (or one hundred), whereas logistic regression is designed to ensure this constraint.

The logistic regression model was estimated using the PROC LOGISTIC function in SAS. Only those variables with $\beta$ parameters significant at the 0.01 level are discussed in the results chapter which follows. 


\section{CHAPTER 6 - Results}

This section will describe the results of both the remote sensing change detection analysis and the logistic regression analysis. The chapter is structured as follows: first, the results of the remote sensing change detection will be identified. Second, the results of the logistic regression model will be identified and discussed for each of the pertinent land-use transitions classified in the remote sensing analysis. Third, the amount of landuse planning tools enacted, the percent values for the land-use change, and the percent values for the control variables will be used to characterize some of the municipalities in the study area. Fourth, is a discussion of the locations of the municipalities that experienced the most proportional forest and AgGrass to a developed land-use change. Last, is a section that contextualizes these results by applying them with the concepts discussed in Chapters 2, 3, and 4.

\section{Remote Sensing Change Detection}

Table 8 below shows the pixel distribution by class for the 1992 and 2002 Landsat data sets following the supervised classification. It also shows the difference of pixel distribution among the classes between the two time periods. Table 9 shows the same information except the pixel values have been converted to acre values. 
Table 8 - Pixel Distribution by Class

\begin{tabular}{|lrr|c|}
\hline \multicolumn{1}{|c}{ Class } & $\mathbf{1 9 9 2}$ & \multicolumn{1}{c}{$\mathbf{2 0 0 2}$} & \multicolumn{1}{c|}{ Difference } \\
\hline Water & 123,724 & 128,779 & 5,055 \\
Urban & 719,068 & 416,236 & $-302,832$ \\
Residential & $1,541,087$ & $3,186,169$ & $1,645,082$ \\
Forest & $9,626,593$ & $10,149,652$ & 523,059 \\
AgGrass & $7,438,288$ & $5,567,924$ & $-1,870,364$ \\
\cline { 1 - 3 } TOTAL & $19,448,760$ & $19,448,760$ & \\
\cline { 1 - 3 } & \multicolumn{3}{|c}{} \\
\hline
\end{tabular}

Table 9 - Acre Distribution by Class

\begin{tabular}{|lrr|c|}
\hline \multicolumn{1}{|c}{ Class } & \multicolumn{1}{c}{$\mathbf{1 9 9 2}$} & \multicolumn{1}{c}{$\mathbf{2 0 0 2}$} & \multicolumn{1}{c|}{ Difference } \\
\cline { 1 - 2 } Water & 27,515 & 28,640 & 1,124 \\
Urban & 159,916 & 92,568 & $-67,348$ \\
Residential & 342,729 & 708,585 & 365,856 \\
Forest & $2,140,897$ & $2,257,222$ & 116,325 \\
AgGrass & $1,654,231$ & $1,238,273$ & $-415,958$ \\
\cline { 1 - 2 } TOTAL & $4,325,288$ & $4,325,288$ & \\
\hline
\end{tabular}

Tables 10 below shows the class change transition from pixel to pixel among the five land-use categories for the entire study area. Table 11, like table 10 above, shows the same information but in acres rather than pixels for convenience. The colors in Tables 10 and 11 correspond with the color scheme used in the legend in Figure 4; each color representing the same information in both the Tables and the Figure. Each data set was classified into 5 land-use classes, therefore there were 20 different land-use change transitions recorded, with 5 additional classes recorded as no-change. Land-use classes urban and residential were recoded together to represent a 'developed' land-use and forest and AgGrass were recoded together to represent a 'less-developed' land use. The gray cells represent the same class-to-class change (i.e., no change). Land-use changes from and to water were not used in the statistical analysis, therefore reducing the number of categories from five to four to be identified in the change detection resulting in 12 land-use change transitions when excluding the 'no change' transition. 
Table 10 - Class Change Distribution by Pixel Count (Percentage)

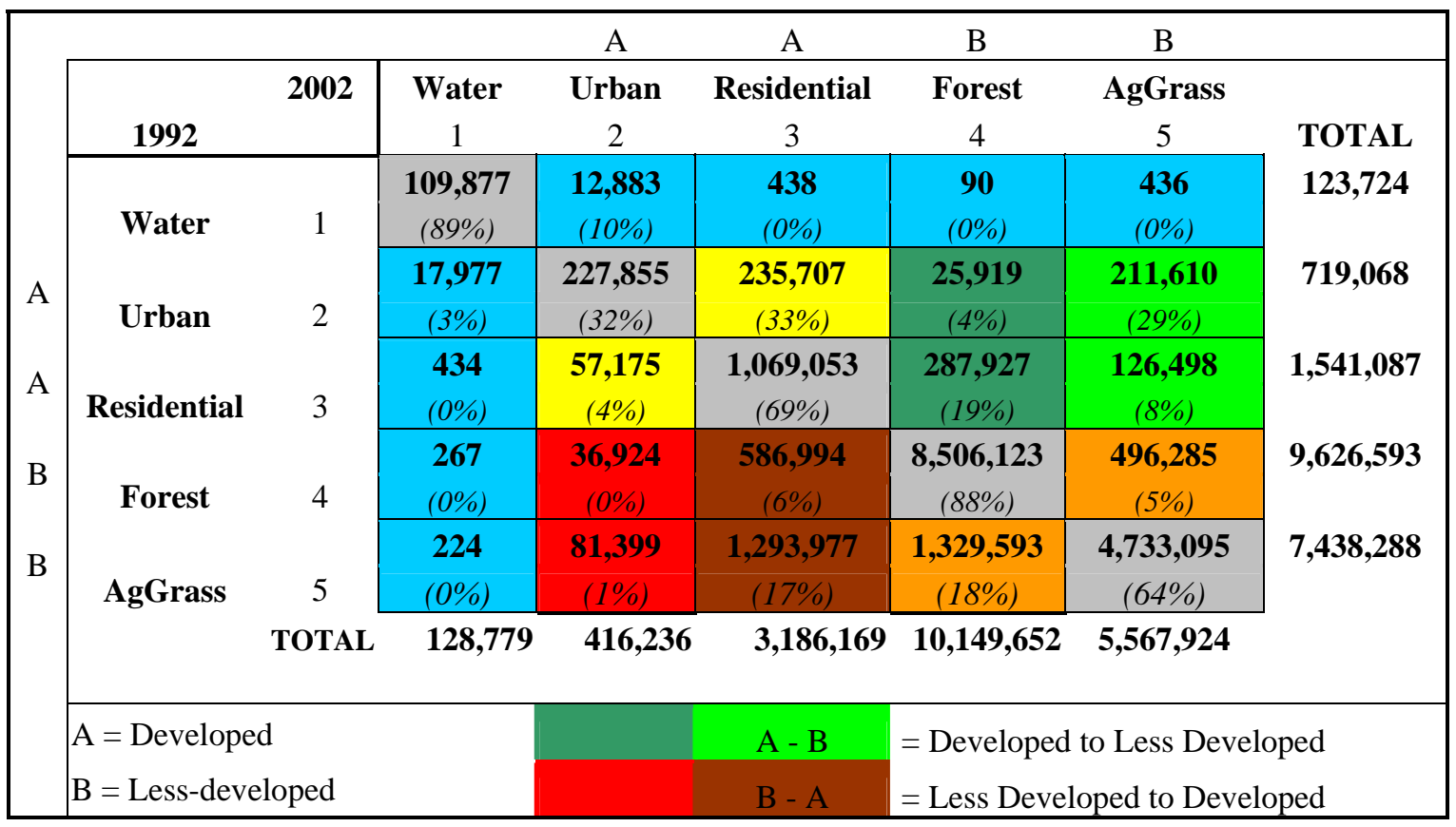

Table 11 - Class Change Distribution by Acre (Percentage)

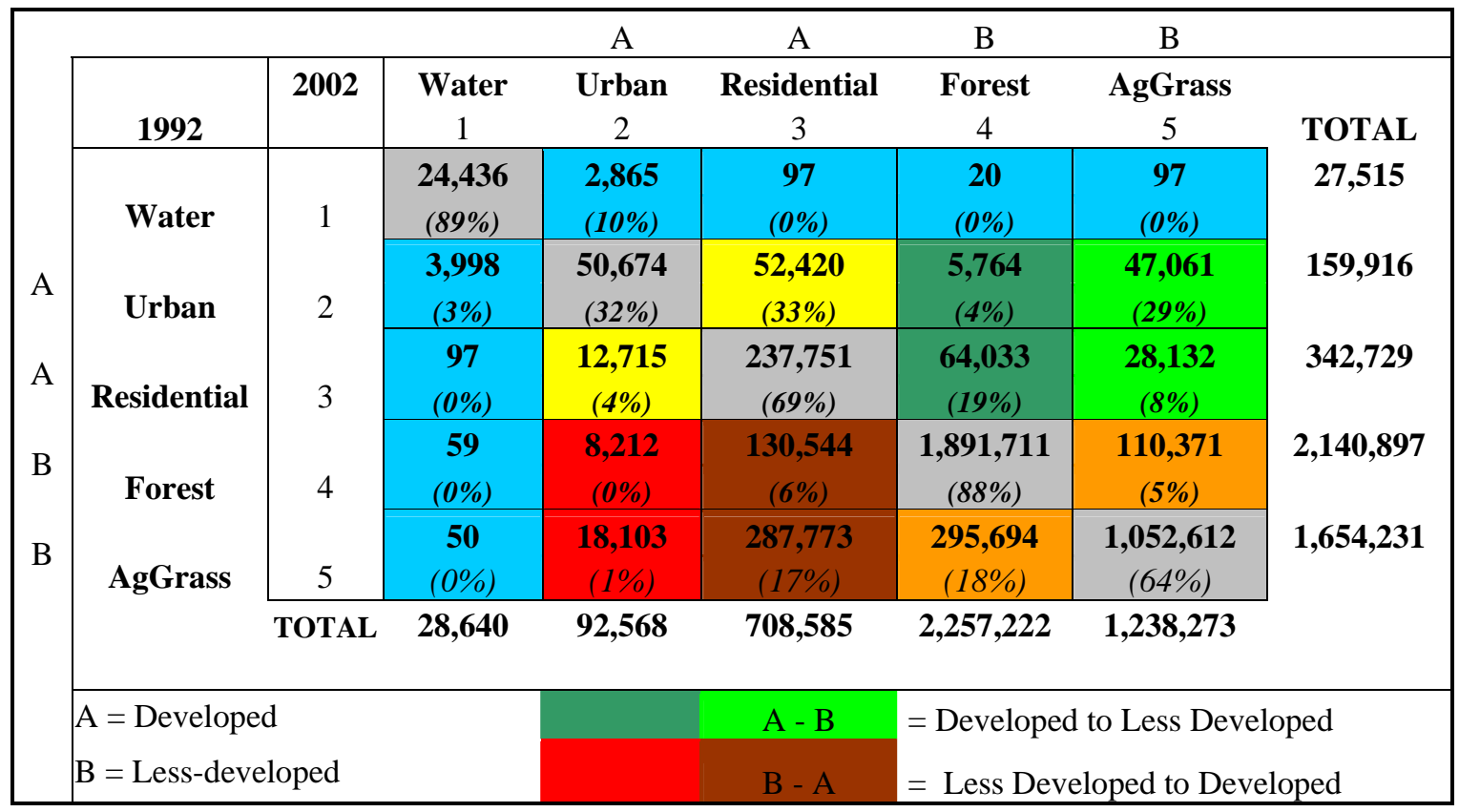

The 12 land-use transitions are displayed in Figure 4 below represented as a 'from - to’ relationship. 
Figure 4 - Land-use Change Transitions
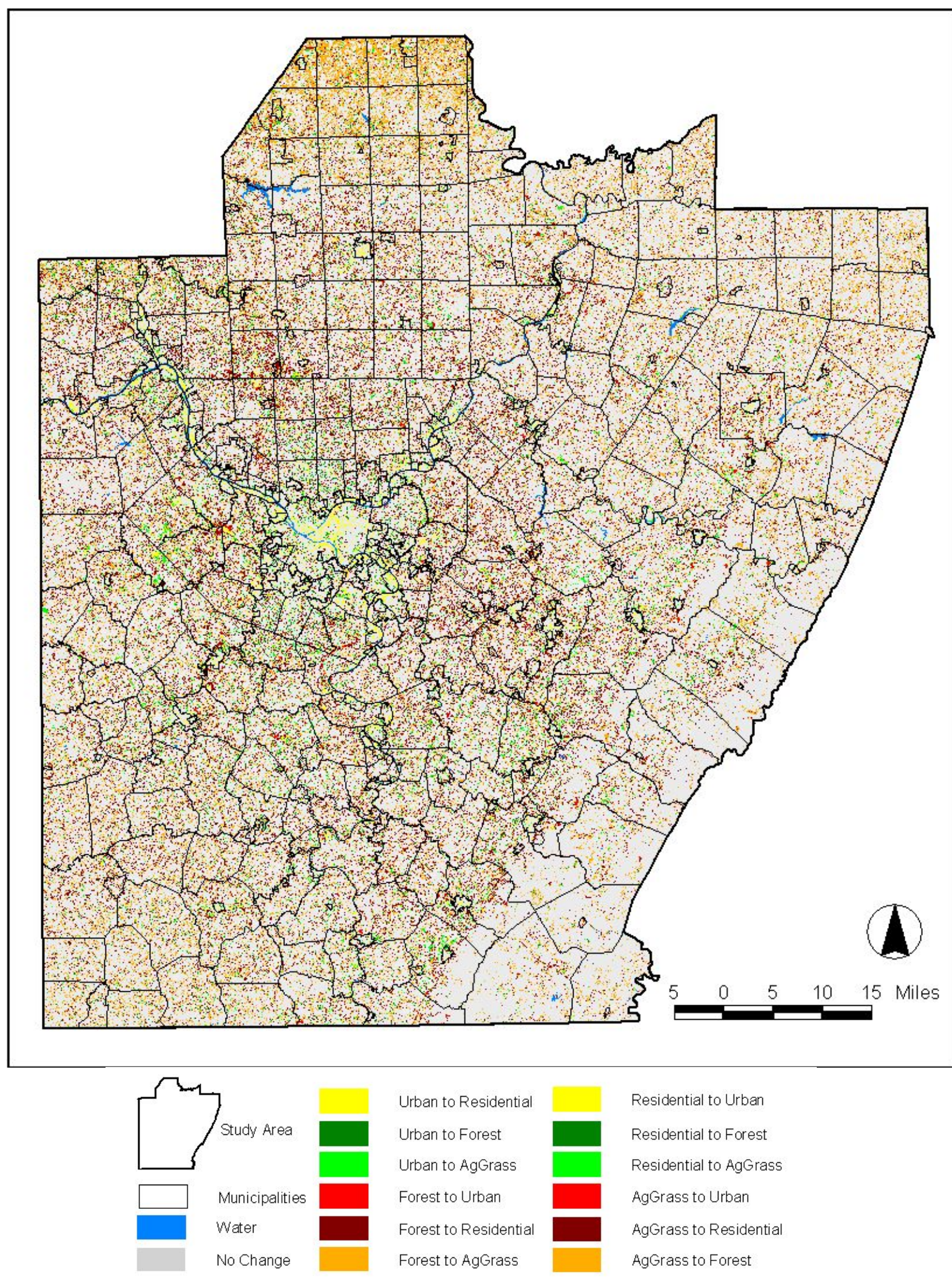

Residential to Urban

Residential to Forest

Residential to AgGrass

AgGrass to Urban

AgGrass to Residential

AgGrass to Forest 


\section{Logistic Regression Model Results}

As explained in section ‘Statistical Analysis - Logistic Regression’ of Chapter 5, the aggregate information represented in Tables 10 and 11 above was spatially distributed to each of the spatially corresponding polygons that represent the municipalities in the study area using the Matrix function. There are 525 municipalities in the study area, but there were 540 polygons due to some municipalities comprising non-contiguous areas. The values for those municipalities that had 2 or more polygons were combined in order to conduct the logistic regression analysis.

Figures 5, 6, 7, and 8 below show the uneven spatial pattern of land-use policies throughout the study area as of 2001. Data on planning tools enacted before the study period (before 1992) were sought but unfortunately were not available. If this data were available it would have been interesting to monitor the spatial diffusion of planning policy throughout the study area. However it is known that most comprehensive plans were enacted in the 1970's and those municipalities that adopted other tools did so shortly after. Of course there is a possibility that some of the municipalities in the sample did enact some of the planning tools during the study period, however, this possibility is expected to be a very small number of the total. It should also be noted than most comprehensive plans and related planning policies were updated in 1989 and in 2000 (Center for Rural Pennsylvania, 2001).

The results of the logistic regression analysis for each type of land-use change are shown in Table 12. Only those coefficients which are significant at the 0.01 level are shown in the table. The sign of a coefficient indicates the direction of the relationship (positive or negative) between the dependent and independent variable, and its size 
indicates the extent to which the independent variable numerically affects the dependent variable. Although the coefficients are not standardized in Table 12 (and in subsequent tables in this chapter), the relative importance of the planning policy variables can be gauged by the size of their coefficients because they are all represented in numerically the same way (as binary variables).

The remainder of this chapter is organized as follows. In the next section the logistic regression results for each type of land-use change are presented sequentially. For each land-use change transition discussed, a table of coefficients corresponding to the land-use change is subset from Table 12 and presented as its own table. Following the table is an explanation of the land-use change coefficients. After each explanation, a map is also provided, each depicting the location of the individual land-use changes within the study area. Following this is a discussion of the regression model results with a focus on the relative importance of each planning policy on the different types of land-use change. Finally, there is a discussion of the results from the perspective of individual municipalities, with a focus on those municipalities which experienced the greatest change to 'developed' and urban land uses. 
Figure 5 - Municipalities with a Comprehensive

Plan in 2001

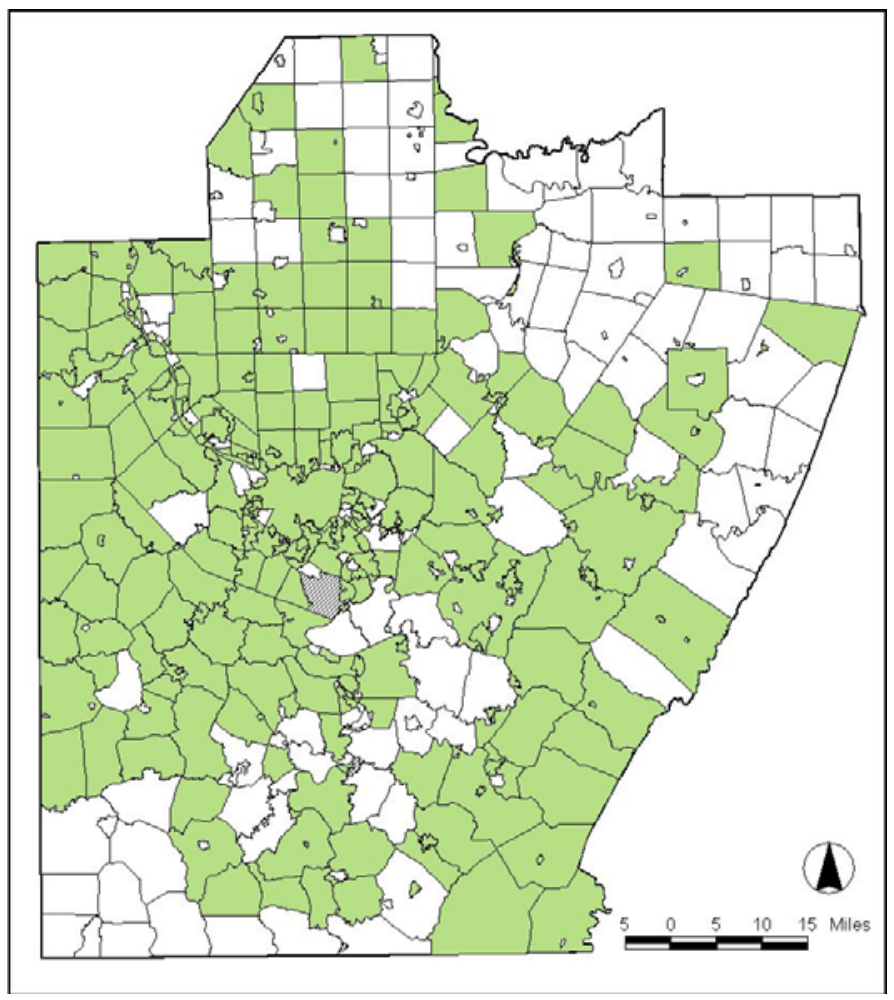

Figure 7 - Municipalities with a Zoning

Ordinance in 2001

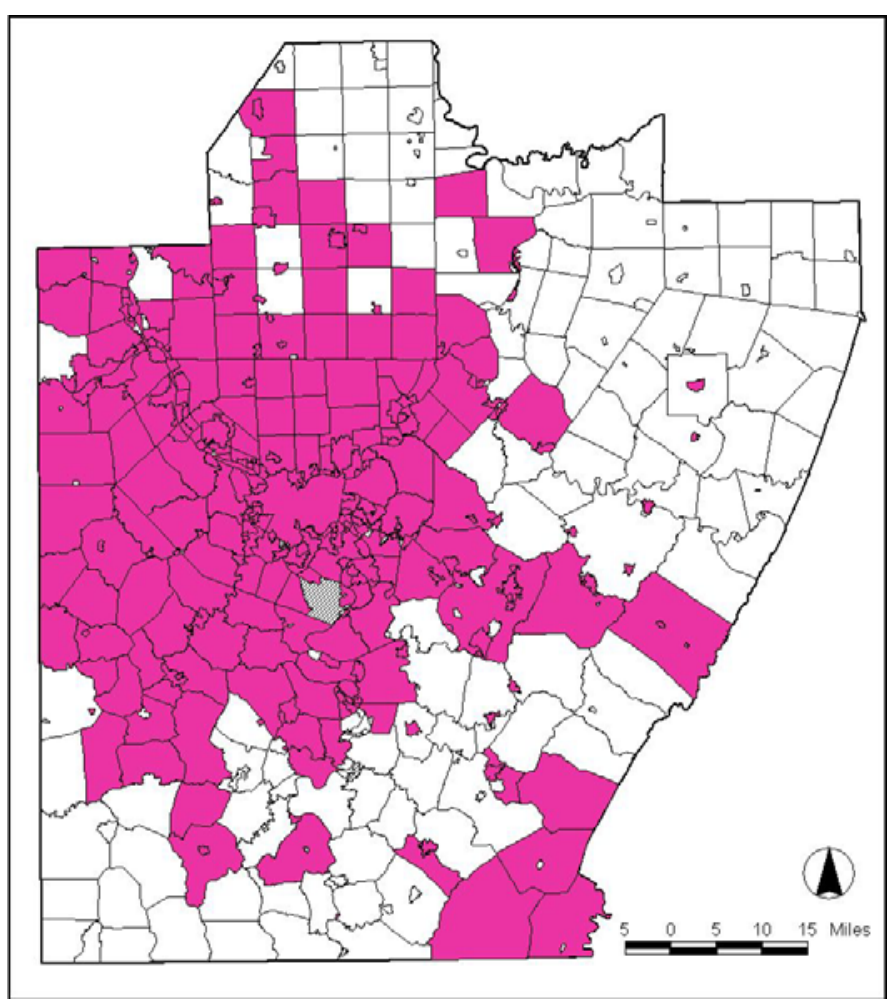

Figure 6 - Municipalities with a Subdivision

Regulation in 2001

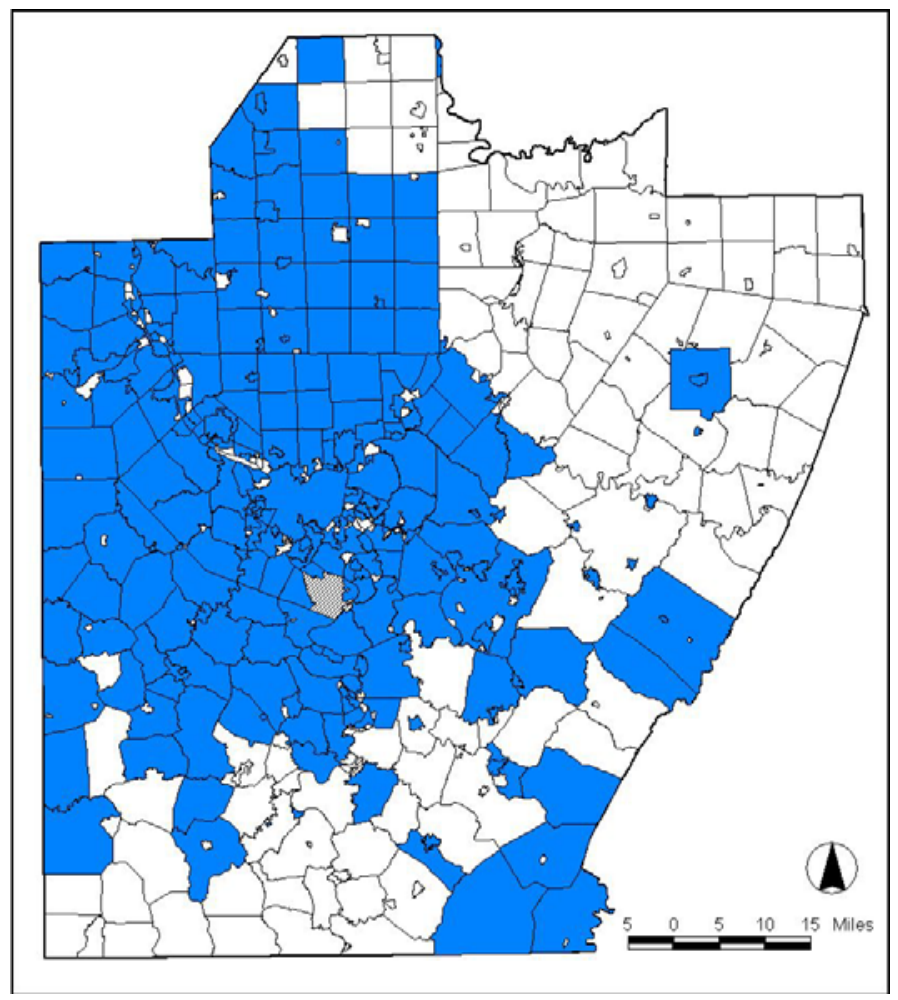

Figure 8 - Municipalities with a Planning Commission in 2001

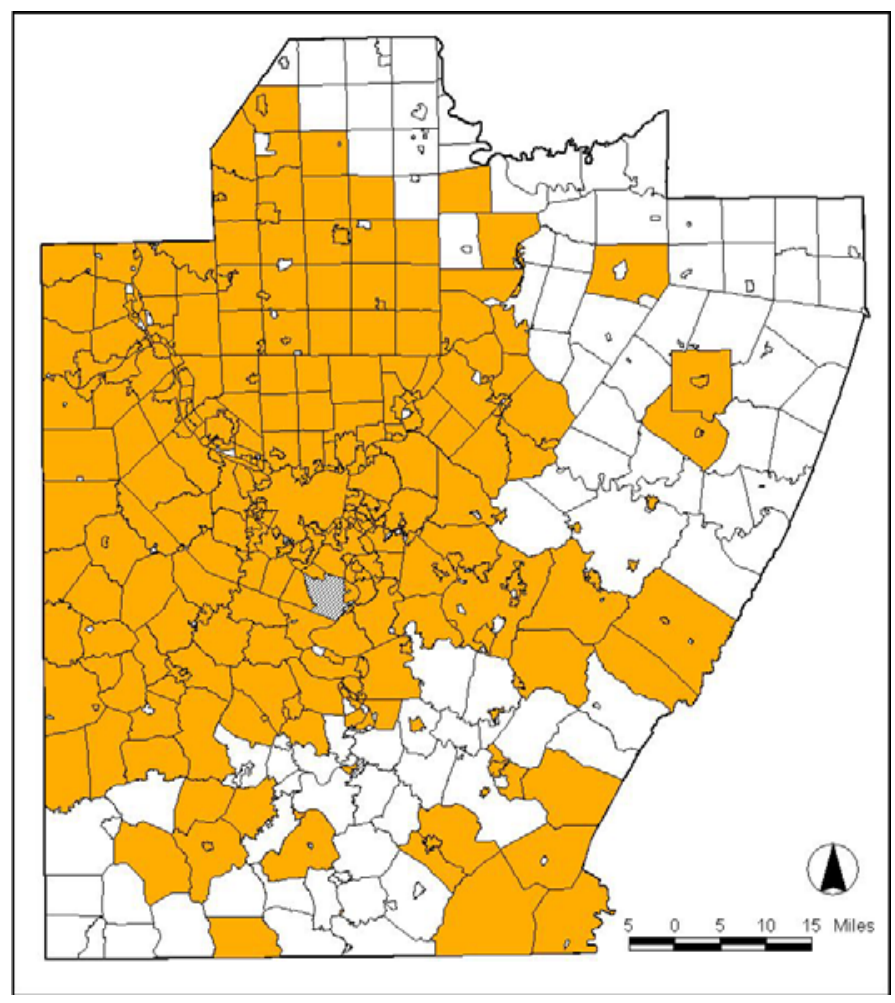

$=$ No Data 
Table 12 - Logistic Regression Results ${ }^{1}$

\begin{tabular}{|c|c|c|c|c|c|c|c|c|c|c|}
\hline \multirow[b]{2}{*}{ Land-use Change Transition } & \multicolumn{4}{|c|}{ Policy Variables } & \multicolumn{6}{|c|}{ Control Variables } \\
\hline & $\begin{array}{c}\text { Comprehensive } \\
\text { Plan }\end{array}$ & $\begin{array}{c}\text { Zoning } \\
\text { Ordinance }\end{array}$ & $\begin{array}{l}\text { Subdivision } \\
\text { Regulation }\end{array}$ & $\begin{array}{l}\text { Planning } \\
\text { Commission }\end{array}$ & $\begin{array}{c}\text { Percent } \\
\text { Existing } \\
\text { Land-use }\end{array}$ & $\begin{array}{l}\text { Average } \\
\text { Population }\end{array}$ & $\begin{array}{l}\text { Change in } \\
\text { Population }\end{array}$ & $\begin{array}{l}\text { Average } \\
\text { Income }\end{array}$ & $\begin{array}{l}\text { Change in } \\
\text { Income }\end{array}$ & $\begin{array}{c}\text { Average } \\
\text { Population } \\
\text { Density }\end{array}$ \\
\hline Developed to Less-developed & -0.13950000 & -0.20540000 & 0.02640000 & -0.06060000 & -0.03430000 & -0.00000023 & -0.00176000 & 0.00000279 & 0.20830000 & 0.00007000 \\
\hline Less-developed to Developed & 0.07700000 & -0.05630000 & 0.13430000 & 0.07940000 & -0.03620000 & 0.00000080 & 0.00076700 & 0.00001100 & -0.33420000 & -0.00026000 \\
\hline Urban to Residential & 0.02130000 & 0.12950000 & 0.18830000 & 0.04380000 & 0.01670000 & -0.00000051 & -0.00206000 & 0.00001900 & 0.23200000 & 0.00015500 \\
\hline Urban to Forest & -0.16900000 & 0.09740000 & -0.14320000 & & -0.13180000 & 0.00000102 & 0.00157000 & -0.00002000 & 0.71590000 & -0.00018000 \\
\hline Urban to AgGrass & -0.13200000 & -0.15400000 & 0.16640000 & -0.14290000 & -0.10010000 & 0.00000416 & & -0.00000862 & -0.06530000 & -0.00061000 \\
\hline Residential to Urban & 0.11600000 & 0.34510000 & & -0.20510000 & 0.00623000 & -0.00000031 & 0.00778000 & -0.00002000 & -0.16980000 & \\
\hline Residential to Forest & -0.18080000 & -0.27320000 & & 0.09570000 & -0.02430000 & 0.00000029 & 0.00053600 & 0.00000765 & 0.10500000 & -0.00003000 \\
\hline Residential to AgGrass & 0.05260000 & -0.05910000 & & -0.11430000 & -0.02040000 & & -0.00227000 & -0.00000399 & -0.06250000 & -0.00009000 \\
\hline Forest to Urban & 0.13080000 & 0.48910000 & -0.10330000 & -0.56190000 & -0.01360000 & -0.00000150 & 0.00888000 & 0.00001100 & -0.96320000 & 0.00018300 \\
\hline Forest to Residential & 0.14320000 & 0.08210000 & 0.17360000 & -0.03450000 & -0.02070000 & -0.00000122 & -0.00379000 & 0.00001400 & 0.11610000 & 0.00015700 \\
\hline Forest to AgGrass & 0.14250000 & & -0.04380000 & -0.02180000 & -0.00922000 & 0.00000052 & -0.00589000 & -0.00000089 & 0.03960000 & -0.00016000 \\
\hline AgGrass to Urban & & 0.18930000 & 0.10750000 & -0.23680000 & -0.00554000 & 0.00000125 & 0.00885000 & 0.00001100 & -1.01070000 & 0.00018100 \\
\hline AgGrass to Residential & 0.08280000 & & 0.22070000 & 0.07430000 & -0.01080000 & -0.00000153 & -0.00169000 & 0.00001500 & -0.06880000 & 0.00036800 \\
\hline AgGrass to Forest & -0.17020000 & 0.01610000 & 0.02900000 & -0.19920000 & 0.00777000 & -0.00000588 & 0.00995000 & -0.00000904 & 0.42650000 & 0.00006700 \\
\hline
\end{tabular}

${ }^{1}$ Only coefficients significant at 0.01 level shown.

Indicates no statistical significance.

Black numbers indicate positive relationship.

Red numbers indicate negative relationship. 


\section{Land-use Coefficients}

1. Change transition Developed to Less-developed

Table 13 - Developed to Less-developed Coefficients

\begin{tabular}{|c|c|c|c|c|c|c|}
\hline Policy & $\begin{array}{c}\text { Comprehensive } \\
\text { Plan }\end{array}$ & Zoning & Subdivision & \begin{tabular}{|c|} 
Planning \\
Commission
\end{tabular} & & \\
\hline & -0.13950000 & -0.20540000 & 0.02640000 & -0.06060000 & & \\
\hline \multirow[t]{2}{*}{ Control } & $\begin{array}{c}\text { Percent Existing } \\
\text { Land-use }\end{array}$ & $\begin{array}{c}\text { Average } \\
\text { Population }\end{array}$ & $\begin{array}{l}\text { Change in } \\
\text { Population }\end{array}$ & $\begin{array}{l}\text { Average } \\
\text { Income }\end{array}$ & $\begin{array}{l}\text { Change in } \\
\text { Income }\end{array}$ & $\begin{array}{c}\text { Average } \\
\text { Population } \\
\text { Density }\end{array}$ \\
\hline & -0.03430000 & -0.00000023 & -0.00176000 & 0.00000279 & 0.20830000 & 0.00007000 \\
\hline
\end{tabular}

Policy Variables-

A positive relationship is observed between developed to less-developed land-use changes and the policy variable subdivision regulation. A negative relationship is observed with the policy variables comprehensive plan, zoning, and planning commission. This means that subdivision regulations are more likely to be present in municipalities that experienced this kind of land-use change during the study time period, and comprehensive plans, zoning, and planning commissions are less likely to be present in these municipalities.

\section{Control Variables-}

The negative coefficient value of the percent existing land-use control variable suggests that the developed to less-developed land-use change was less likely to occur in those municipalities with larger amounts of the existing land-use during the study time period. The negative coefficient for the average population and change in population control variables suggests that this value is relatively lower in the 
municipalities that experienced this type of change than the rest of the sample during the study time period. The positive coefficients for average income; change in average income and the average population density suggest these values were relatively higher in the municipalities that experienced this type of change.

\section{Figure 9 - Developed to Less-developed Change Transition}

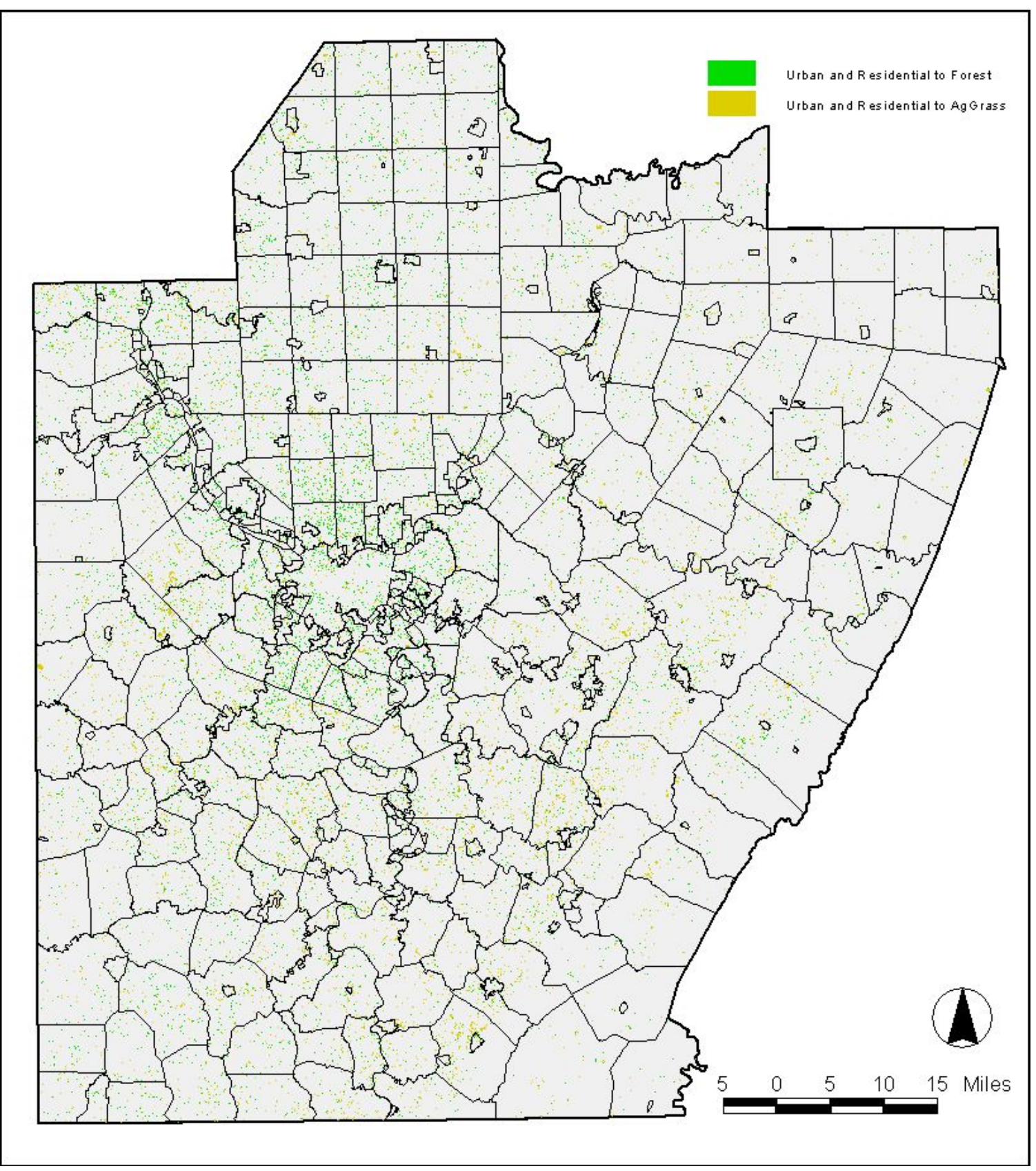


2. Change transition Less-developed to Developed

Table 14 - Less-developed to Developed Coefficients

\begin{tabular}{|c|c|c|c|c|c|c|}
\hline \multirow[t]{2}{*}{ Policy } & $\begin{array}{c}\text { Comprehensive } \\
\text { Plan }\end{array}$ & Zoning & Subdivision & $\begin{array}{c}\text { Planning } \\
\text { Commission }\end{array}$ & & \\
\hline & 0.07700000 & -0.05630000 & 0.13430000 & 0.07940000 & & \\
\hline \multirow[t]{2}{*}{ Control } & $\begin{array}{c}\text { Percent Existing } \\
\text { Land-use }\end{array}$ & $\begin{array}{c}\text { Average } \\
\text { Population }\end{array}$ & $\begin{array}{l}\text { Change in } \\
\text { Population }\end{array}$ & $\begin{array}{l}\text { Average } \\
\text { Income }\end{array}$ & $\begin{array}{l}\text { Change in } \\
\text { Income }\end{array}$ & $\begin{array}{c}\text { Average } \\
\text { Population } \\
\text { Density }\end{array}$ \\
\hline & -0.03620000 & 0.00000080 & 0.00076700 & 0.00001100 & -0.33420000 & -0.00026000 \\
\hline
\end{tabular}

Policy Variables-

A positive relationship is observed between less-developed to developed land-use changes and the policy variables comprehensive plan, subdivision regulation and planning commission. A negative relationship is observed with the policy variable zoning. This means that a comprehensive plan, subdivision regulation, and planning commission were likely to be present in municipalities that experienced this kind of landuse change during the study time period, and zoning was less likely to be present in these municipalities.

\section{Control Variables-}

The negative coefficient value of the percent existing land-use control variable suggests that the less-developed to developed land-use change was less likely to occur in those municipalities with larger amounts of the existing land-use during the study time period. The positive coefficients for average population, change in population and average income control variables suggests that these values are relatively higher in the municipalities that experienced this type of change than the rest of the sample during the study time period. The negative coefficients for change in average 
income and the average population density suggest these values were relatively lower in the municipalities that experienced this type of change.

Figure 10 - Less-developed to Developed Change Transition

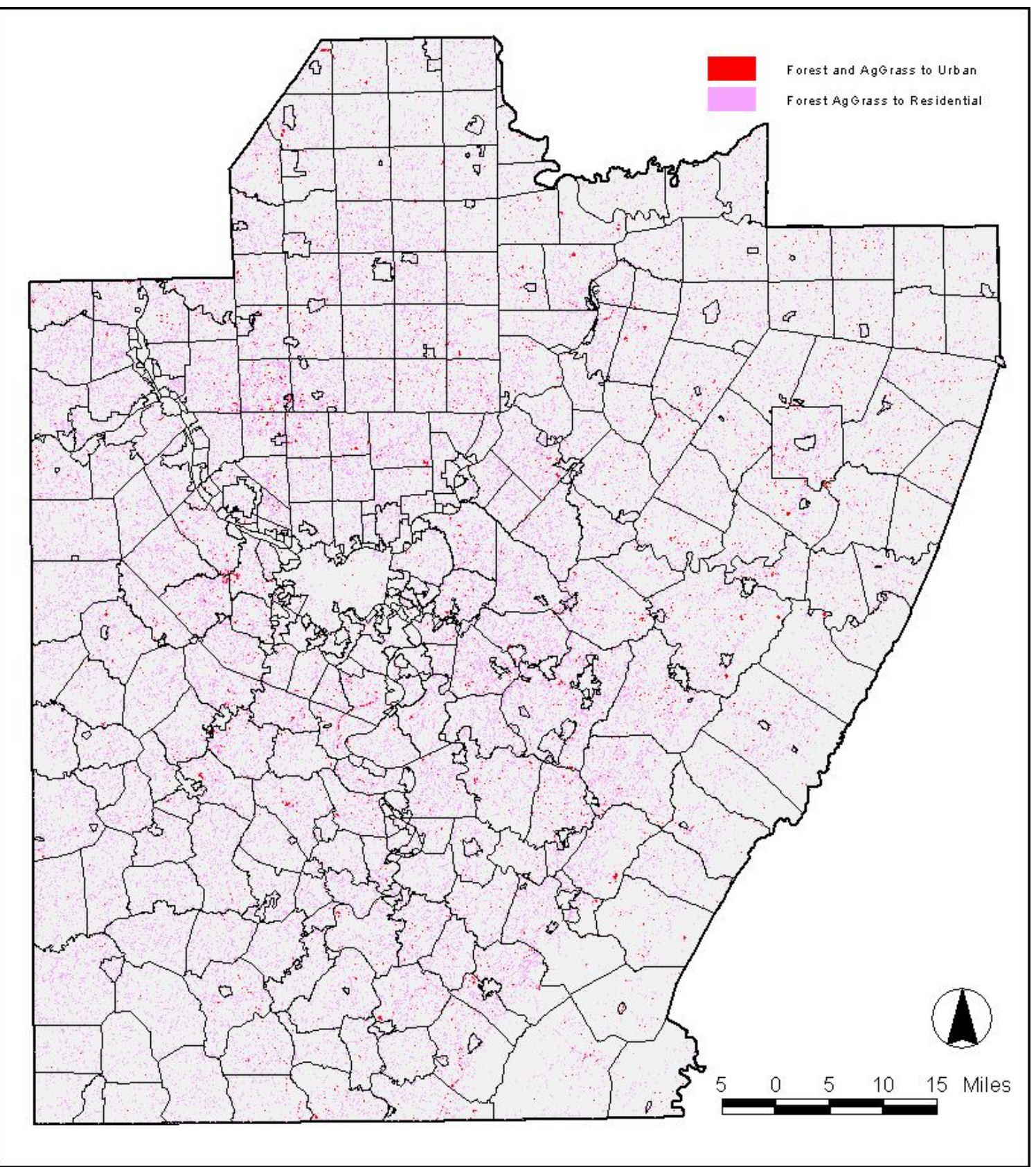


3. Change transition Urban to Residential

Table 15 - Urban to Residential Coefficients

\begin{tabular}{|c|c|c|c|c|c|c|}
\hline Policy & \begin{tabular}{|c|} 
Comprehensive \\
Plan
\end{tabular} & Zoning & Subdivision & $\begin{array}{c}\text { Planning } \\
\text { Commission }\end{array}$ & & \\
\hline & 0.02130000 & 0.12950000 & 0.18830000 & 0.04380000 & & \\
\hline \multirow[t]{2}{*}{ Control } & $\begin{array}{c}\text { Percent Existing } \\
\text { Land-use }\end{array}$ & $\begin{array}{c}\text { Average } \\
\text { Population }\end{array}$ & $\begin{array}{l}\text { Change in } \\
\text { Population }\end{array}$ & $\begin{array}{l}\text { Average } \\
\text { Income }\end{array}$ & $\begin{array}{l}\text { Change in } \\
\text { Income }\end{array}$ & $\begin{array}{c}\text { Average } \\
\text { Population } \\
\text { Density }\end{array}$ \\
\hline & 0.01670000 & -0.00000051 & -0.00206000 & 0.00001900 & 0.23200000 & 0.00015500 \\
\hline
\end{tabular}

Policy Variables-

A positive relationship was observed between urban to residential land-use changes and all four planning policy variables: comprehensive plan, zoning, subdivision regulation, and planning commission. This means that of all of the planning tools were more likely to be present in municipalities that experienced this kind of land-use change during the study time period.

\section{Control Variables-}

The positive coefficient value of the percent existing land-use control variable suggests that the urban to residential land-use change was more likely to occur in those municipalities with larger amounts of the existing land-use during the study time period. The negative coefficient for the average population and change in population control variable suggests that this value is relatively lower in the municipalities that experienced this type of change than the rest of the sample during the study time period. The positive coefficients for average income, change in income and average population density suggest these values were relatively higher in the municipalities that experienced this type of change. 
Figure 11 - Urban to Residential Change Transition

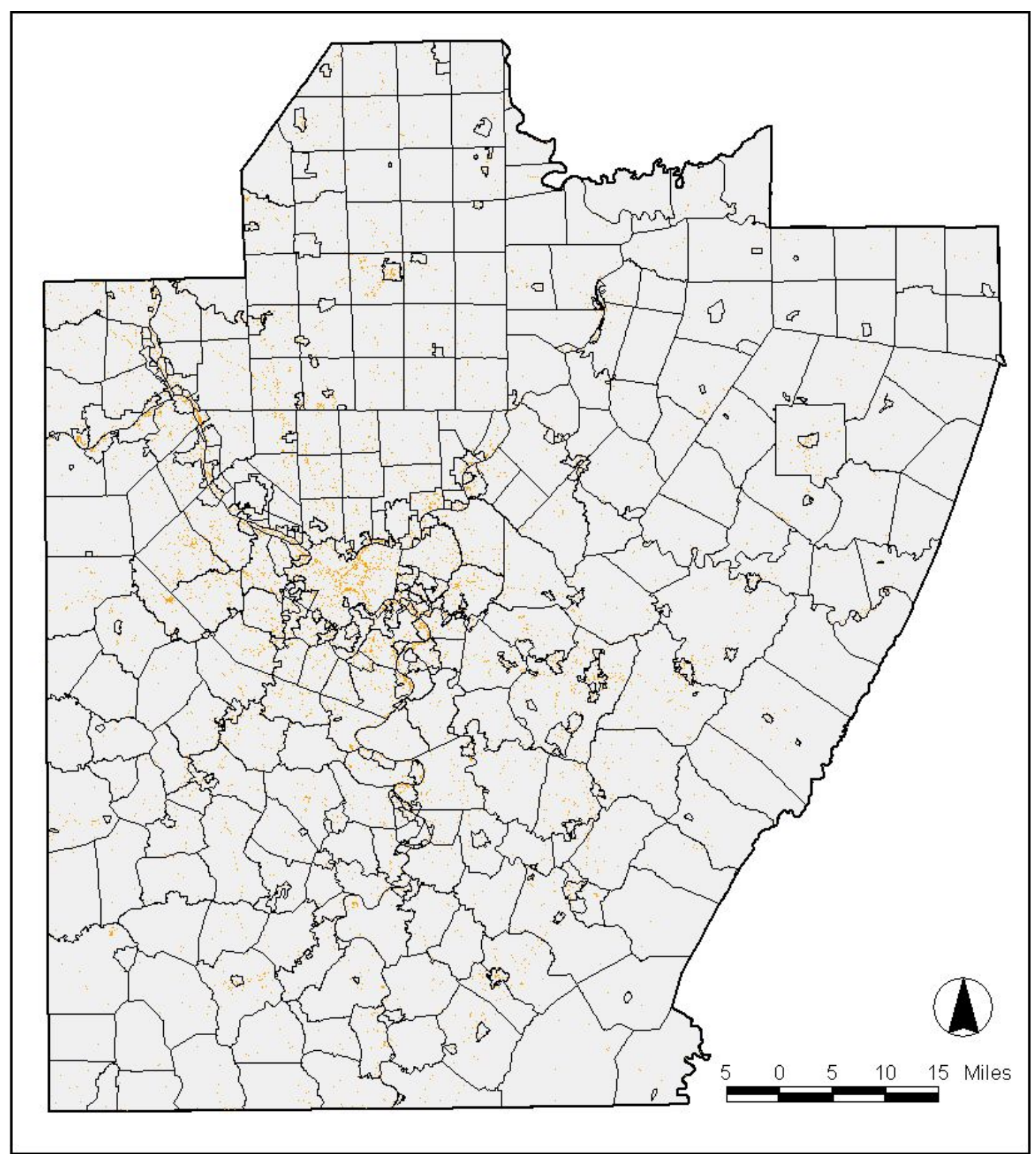




\section{Change transition Urban to Forest}

Table 16 - Urban to Forest Coefficients

\begin{tabular}{|c|c|c|c|c|c|c|}
\hline \multirow[t]{2}{*}{ Policy } & $\begin{array}{c}\text { Comprehensive } \\
\text { Plan }\end{array}$ & Zoning & Subdivision & $\begin{array}{c}\text { Planning } \\
\text { Commission }\end{array}$ & & \\
\hline & -0.16900000 & 0.09740000 & -0.14320000 & & & \\
\hline \multirow[t]{2}{*}{ Control } & $\begin{array}{c}\text { Percent Existing } \\
\text { Land-use }\end{array}$ & $\begin{array}{l}\text { Average } \\
\text { Population }\end{array}$ & $\begin{array}{l}\text { Change in } \\
\text { Population }\end{array}$ & $\begin{array}{l}\text { Average } \\
\text { Income }\end{array}$ & $\begin{array}{l}\text { Change in } \\
\text { Income }\end{array}$ & $\begin{array}{c}\text { Average } \\
\text { Population } \\
\text { Density }\end{array}$ \\
\hline & -0.13180000 & 0.00000102 & 0.00157000 & -0.00002000 & 0.71590000 & -0.00018000 \\
\hline
\end{tabular}

Policy Variables-

A negative relationship was observed between urban to forest land-use changes and the policy variables comprehensive plan and subdivision regulation. A positive relationship was observed with the policy variable zoning. This means that the presence of a comprehensive plan and subdivision regulation were less likely to be present in municipalities that experienced this kind of land-use change during the study time period, and zoning was more likely to be present in these municipalities. The presence or absence of a planning commission was not statistically significant with this land-use change transition.

\section{Control Variables-}

The negative coefficient value of the percent existing land-use control variable suggests that the urban to forest land-use change was less likely to occur in those municipalities with larger amounts of the existing land-use during the study time period. The positive coefficient for the average population, change in population and change in income control variables suggests that these values are relatively higher in the 
municipalities that experienced this type of change than the rest of the sample during the study time period. The negative coefficients for average income and average population density suggest these values were relatively lower in the municipalities that experienced this type of change.

Figure 12 - Urban to Forest Change Transition

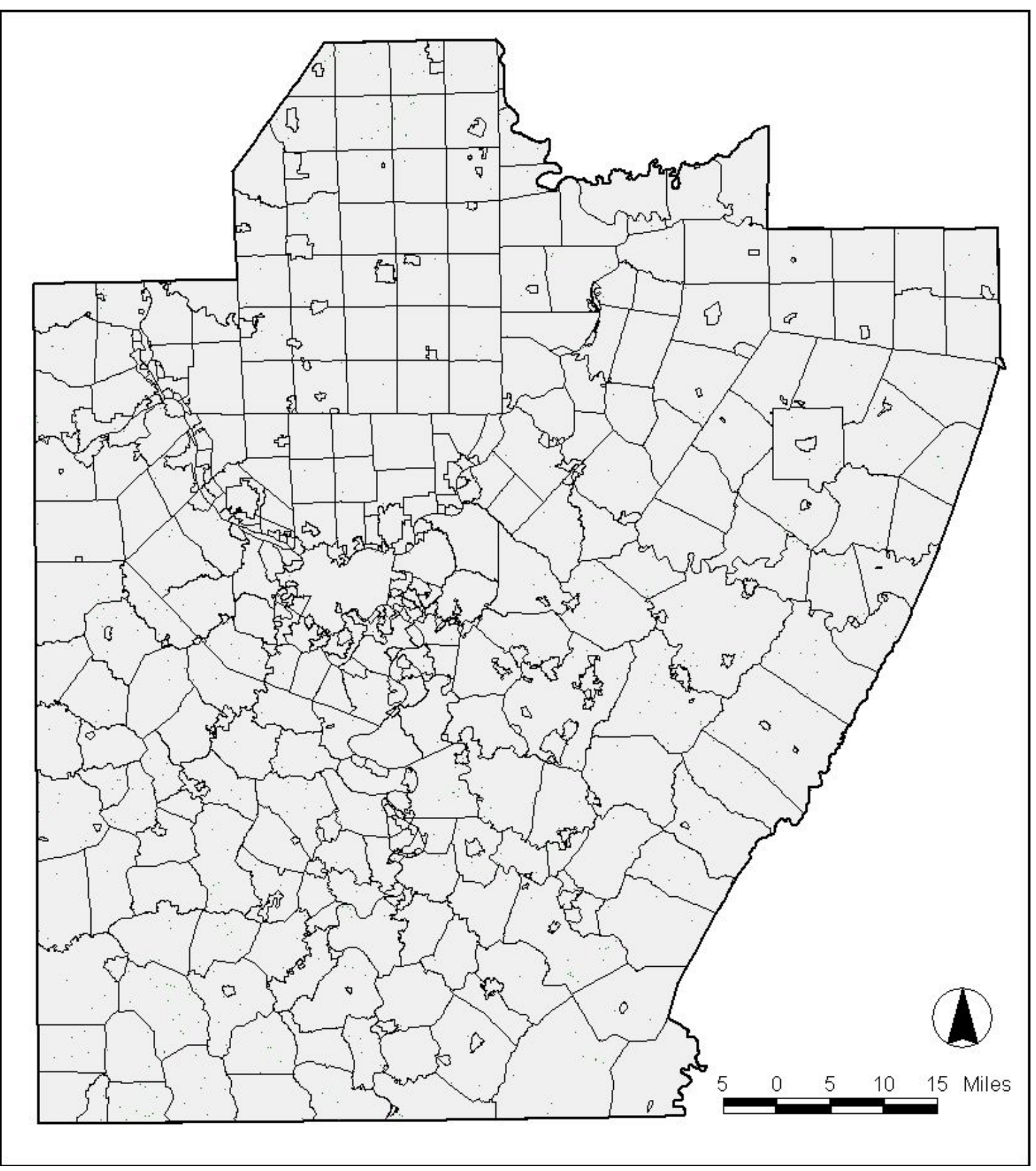


5. Change transition Urban to AgGrass

Table 17 - Urban to AgGrass Coefficients

\begin{tabular}{|c|c|c|c|c|c|c|}
\hline Policy & $\begin{array}{c}\text { Comprehensive } \\
\text { Plan }\end{array}$ & Zoning & Subdivision & $\begin{array}{c}\text { Planning } \\
\text { Commission }\end{array}$ & & \\
\hline & -0.13200000 & -0.15400000 & 0.16640000 & -0.14290000 & & \\
\hline \multirow[t]{2}{*}{ Control } & $\begin{array}{c}\text { Percent Existing } \\
\text { Land-use }\end{array}$ & $\begin{array}{c}\text { Average } \\
\text { Population }\end{array}$ & $\begin{array}{l}\text { Change in } \\
\text { Population }\end{array}$ & $\begin{array}{l}\text { Average } \\
\text { Income }\end{array}$ & $\begin{array}{l}\text { Change in } \\
\text { Income }\end{array}$ & \begin{tabular}{|c|} 
Average \\
Population \\
Density
\end{tabular} \\
\hline & -0.10010000 & 0.00000416 & & -0.00000862 & -0.06530000 & -0.00061000 \\
\hline
\end{tabular}

Policy Variables-

A negative relationship was observed between urban to AgGrass land-use changes and the policy variables comprehensive plan, zoning and planning commission. A positive relationship was observed with the policy variable zoning. This means that the presence of a comprehensive plan, zoning and planning commission were less likely to be present in municipalities that experienced this kind of land-use change during the study time period, and zoning was more likely to be present in these municipalities.

\section{Control Variables-}

The_negative coefficient value of the percent existing land-use control variable suggests that the urban to AgGrass land-use change was less likely to occur in those municipalities with larger amounts of the existing land-use during the study time period. The positive coefficient for the average population control variables suggests that this value is relatively higher in the municipalities that experienced this type of change than the rest of the sample during the study time period. The negative coefficients for average income, change in income and average population density suggest these values 
were relatively lower in the municipalities that experienced this type of change. The control variable change in population was not statistically significant.

Figure 13 - Urban to AgGrass Change Transition

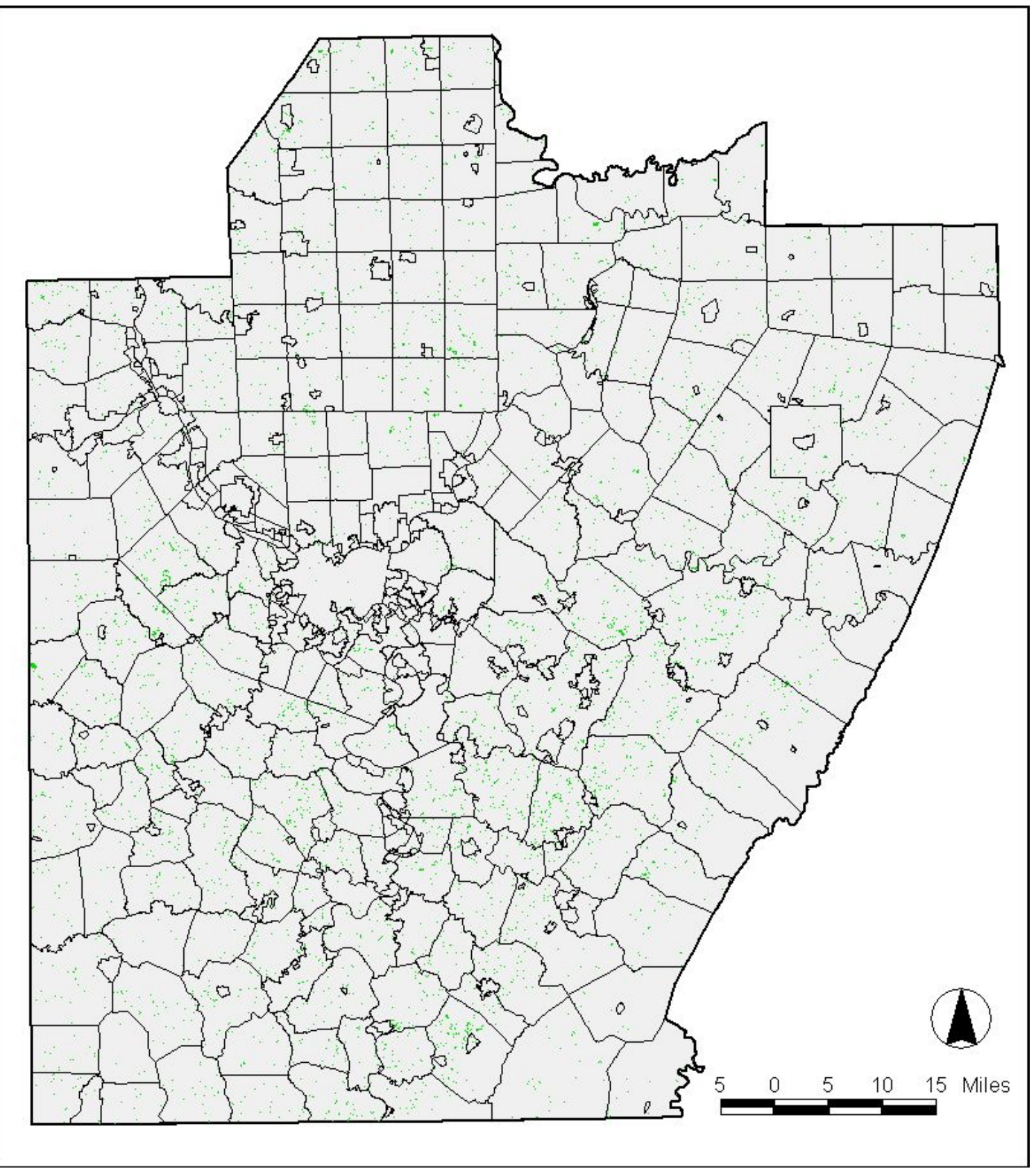


6. Change transition Residential to Urban

Table 18 - Residential to Urban Coefficients

\begin{tabular}{|c|c|c|c|c|c|c|}
\hline Policy & $\begin{array}{c}\text { Comprehensive } \\
\text { Plan }\end{array}$ & Zoning & Subdivision & \begin{tabular}{|c|} 
Planning \\
Commission
\end{tabular} & & \\
\hline & 0.11600000 & 0.34510000 & & -0.20510000 & & \\
\hline \multirow[t]{2}{*}{ Control } & $\begin{array}{c}\text { Percent Existing } \\
\text { Land-use }\end{array}$ & $\begin{array}{c}\text { Average } \\
\text { Population }\end{array}$ & $\begin{array}{l}\text { Change in } \\
\text { Population }\end{array}$ & $\begin{array}{l}\text { Average } \\
\text { Income }\end{array}$ & $\begin{array}{l}\text { Change in } \\
\text { Income }\end{array}$ & $\begin{array}{c}\text { Average } \\
\text { Population } \\
\text { Density }\end{array}$ \\
\hline & 0.00623000 & -0.00000031 & 0.00778000 & -0.00002000 & -0.16980000 & \\
\hline
\end{tabular}

Policy Variables-

A positive relationship was observed between residential to urban land-use changes and the policy variables comprehensive plan and zoning. A negative relationship was observed with the policy variable planning commission. This means that the presence of a comprehensive plan and zoning were more likely to be present in municipalities that experienced this kind of land-use change during the study time period, and a planning commission was less likely to be present in these municipalities. The presence or absence of subdivision regulation was not statistically significant with this land-use change transition.

\section{Control Variables-}

The positive coefficient value of the percent existing land-use control variable suggests that the residential to urban land-use change was more likely to occur in those municipalities with larger amounts of the existing land-use during the study time period. The negative coefficient for the average population, average income and change in income control variables suggests that this value is relatively lower in the municipalities that experienced this type of change than the rest of the sample during the 
study time period. The positive coefficient for change in population suggests these values were relatively higher in the municipalities that experienced this type of change. The control variable average population density was not statistically significant.

Figure 14 - Residential to Urban Change Transition

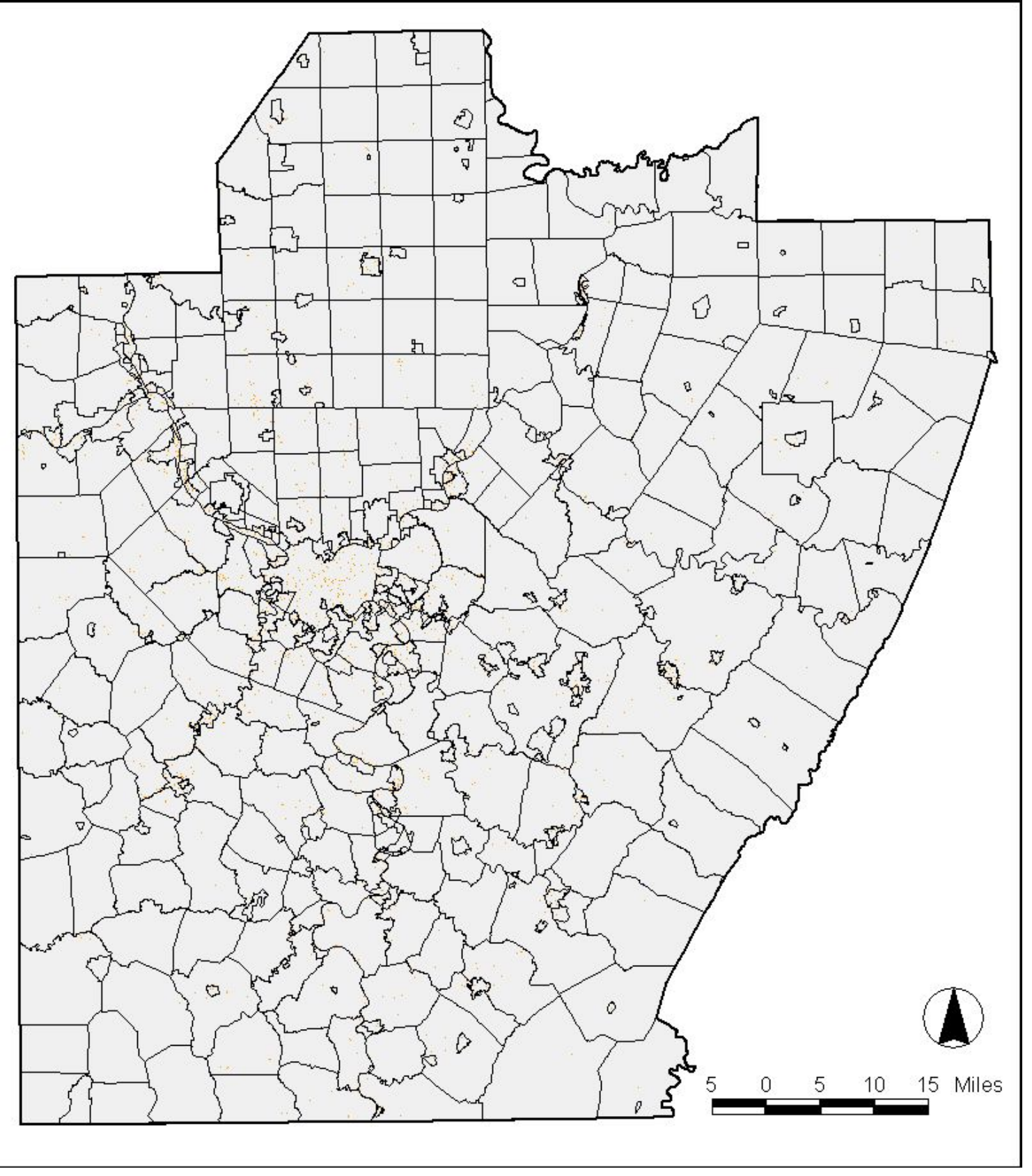


7. Change transition Residential to Forest

Table 19 - Residential to Forest Coefficients

\begin{tabular}{|c|c|c|c|c|c|c|}
\hline \multirow[t]{2}{*}{ Policy } & $\begin{array}{c}\text { Comprehensive } \\
\text { Plan }\end{array}$ & Zoning & Subdivision & $\begin{array}{c}\text { Planning } \\
\text { Commission }\end{array}$ & & \\
\hline & -0.18080000 & -0.27320000 & & 0.09570000 & & \\
\hline \multirow[t]{2}{*}{ Control } & $\begin{array}{c}\text { Percent Existing } \\
\text { Land-use }\end{array}$ & $\begin{array}{c}\text { Average } \\
\text { Population }\end{array}$ & $\begin{array}{l}\text { Change in } \\
\text { Population }\end{array}$ & $\begin{array}{l}\text { Average } \\
\text { Income }\end{array}$ & $\begin{array}{l}\text { Change in } \\
\text { Income }\end{array}$ & $\begin{array}{c}\text { Average } \\
\text { Population } \\
\text { Density }\end{array}$ \\
\hline & -0.02430000 & 0.00000029 & 0.00053600 & 0.00000765 & 0.10500000 & -0.00003000 \\
\hline
\end{tabular}

Policy Variables-

A_negative relationship was observed between residential to forest landuse changes and the policy variables comprehensive plan and zoning.. A positive relationship was observed with the policy variable planning commission. This means that the presence of a comprehensive plan and zoning were less likely to be present in municipalities that experienced this kind of land-use change during the study time period, and a planning commission was more likely to be present in these municipalities. The presence or absence of subdivision regulation was not statistically significant with this land-use change transition.

\section{Control Variables-}

The negative coefficient value of the percent existing land-use control variable suggests that the residential to forest land-use change was less likely to occur in those municipalities with larger amounts of the existing land-use during the study time period. The positive coefficient for the average population, change in population, average income and change in income control variables suggests that these values are 
relatively higher in the municipalities that experienced this type of change than the rest of the sample during the study time period. The negative coefficient for average population density suggests these values were relatively lower in the municipalities that experienced this type of change.

\section{Figure 15 - Residential to Forest Change Transition}

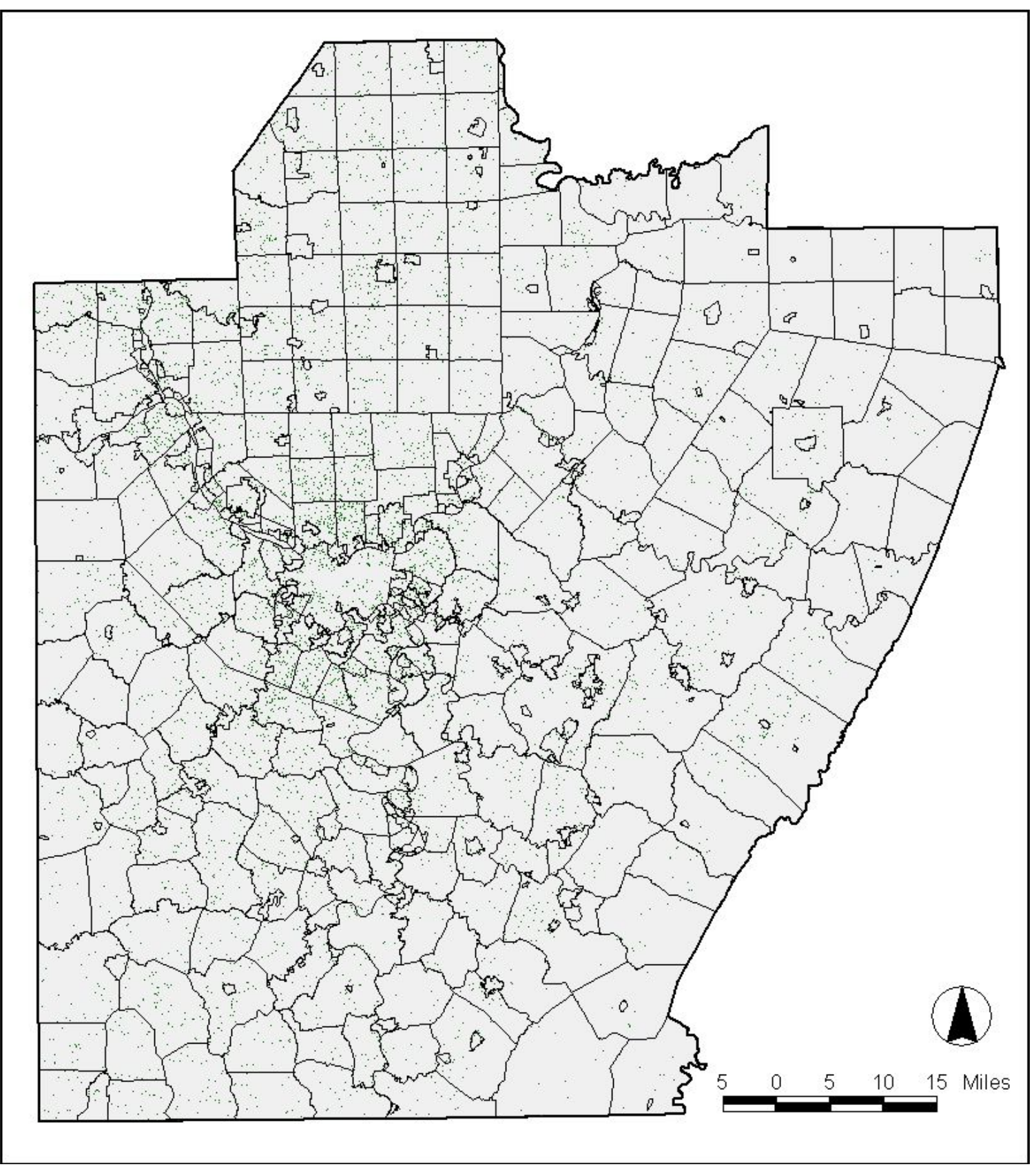


8. Change transition Residential to AgGrass

Table 20 - Residential to AgGrass Coefficients

\begin{tabular}{|c|c|c|c|c|c|c|}
\hline \multirow[t]{2}{*}{ Policy } & $\begin{array}{c}\text { Comprehensive } \\
\text { Plan }\end{array}$ & Zoning & Subdivision & $\begin{array}{c}\text { Planning } \\
\text { Commission }\end{array}$ & & \\
\hline & 0.05260000 & -0.05910000 & & -0.11430000 & & \\
\hline \multirow[t]{2}{*}{ Control } & $\begin{array}{c}\text { Percent Existing } \\
\text { Land-use }\end{array}$ & $\begin{array}{c}\text { Average } \\
\text { Population }\end{array}$ & $\begin{array}{l}\text { Change in } \\
\text { Population }\end{array}$ & $\begin{array}{l}\text { Average } \\
\text { Income }\end{array}$ & $\begin{array}{l}\text { Change in } \\
\text { Income }\end{array}$ & $\begin{array}{l}\text { Average } \\
\text { Population } \\
\text { Density }\end{array}$ \\
\hline & -0.02040000 & & -0.00227000 & -0.00000399 & -0.06250000 & -0.00009000 \\
\hline
\end{tabular}

Policy Variables-

A positive relationship was observed between residential to AgGrass landuse changes and the policy variable comprehensive plan. A negative relationship was observed with the policy variables zoning and planning commission. This means that the presence of a comprehensive plan was more likely to be present in municipalities that experienced this kind of land-use change during the study time period, and zoning and a planning commission were less likely to be present in these municipalities. The presence or absence of subdivision regulation was not statistically significant with this land-use change transition.

\section{Control Variables-}

The negative coefficient value of the percent existing land-use control variable suggests that the residential to AgGrass land-use change was less likely to occur in those municipalities with larger amounts of the existing land-use during the study time period. The negative coefficients for the control variables change in population, average income, change in income and average population density suggest these values were relatively lower in the municipalities that experienced this type of change during the 
study time period. The control variable average population density was not statistically significant.

Figure 16 - Residential to AgGrass Change Transition

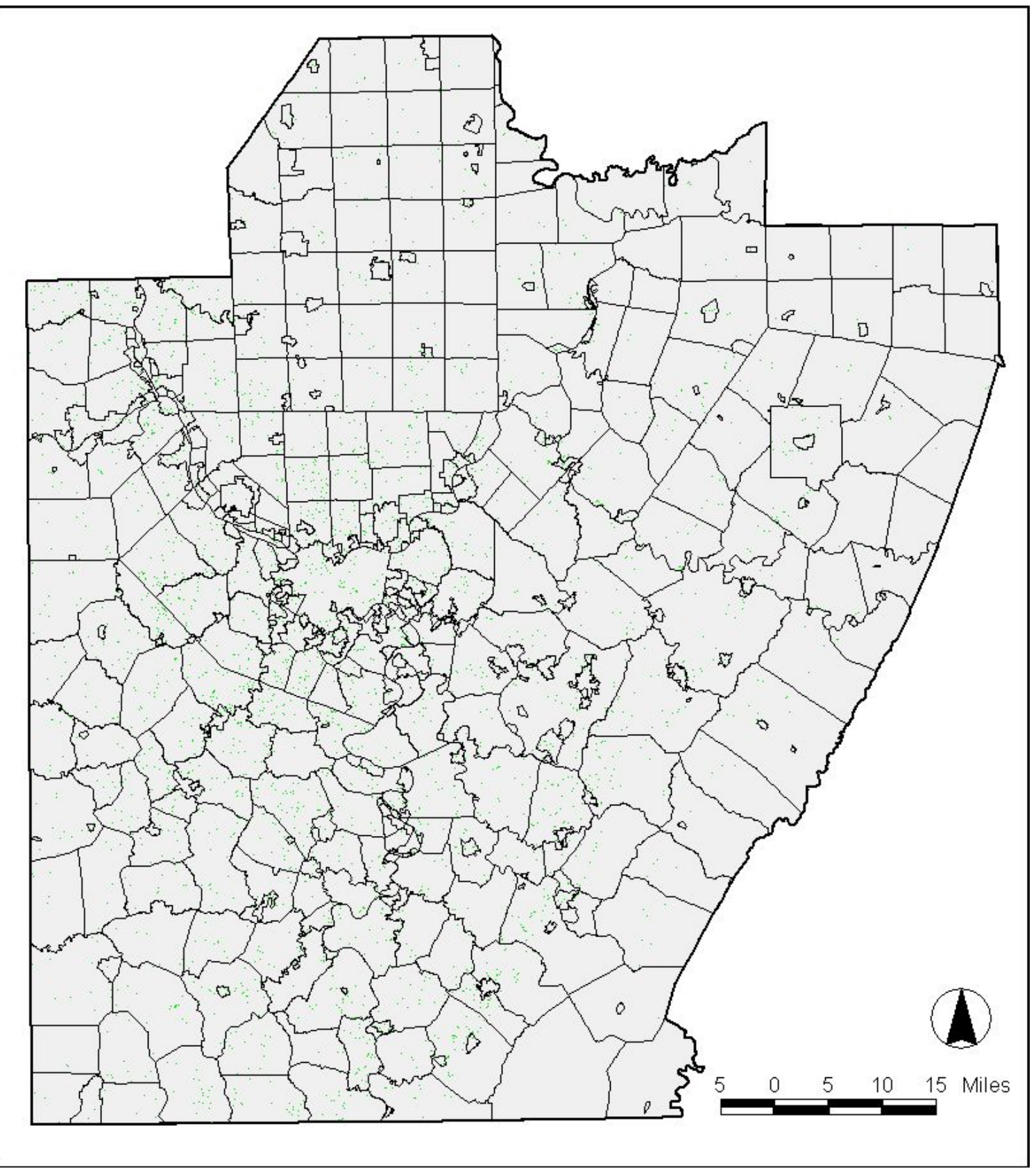


9. Change transition Forest to Urban

Table 21 - Forest to Urban Coefficients

\begin{tabular}{|c|c|c|c|c|c|c|}
\hline \multirow[t]{2}{*}{ Policy } & $\begin{array}{c}\text { Comprehensive } \\
\text { Plan }\end{array}$ & Zoning & Subdivision & $\begin{array}{c}\text { Planning } \\
\text { Commission }\end{array}$ & & \\
\hline & 0.13080000 & 0.48910000 & -0.10330000 & -0.56190000 & & \\
\hline \multirow[t]{2}{*}{ Control } & $\begin{array}{l}\text { Percent Existing } \\
\text { Land-use }\end{array}$ & $\begin{array}{c}\text { Average } \\
\text { Population }\end{array}$ & $\begin{array}{l}\text { Change in } \\
\text { Population }\end{array}$ & $\begin{array}{l}\text { Average } \\
\text { Income }\end{array}$ & $\begin{array}{l}\text { Change in } \\
\text { Income }\end{array}$ & $\begin{array}{c}\text { Average } \\
\text { Population } \\
\text { Density }\end{array}$ \\
\hline & -0.01360000 & -0.00000150 & 0.00888000 & 0.00001100 & -0.96320000 & 0.00018300 \\
\hline
\end{tabular}

Policy Variables-

A positive relationship was observed between forest to urban land-use changes and the policy variables comprehensive plan and zoning. A negative relationship was observed with the policy variables subdivision regulation and planning commission. This means that the presence of a comprehensive plan and zoning were more likely to be present in municipalities that experienced this kind of land-use change during the study time period, and subdivision regulation and a planning commission were less likely to be present in these municipalities.

\section{Control Variables-}

The negative coefficient value of the percent existing land-use control variable suggests that the forest to urban land-use change was less likely to occur in those municipalities with larger amounts of the existing land-use during the study time period. The negative coefficient for the average population and change in income control variables suggests that these values are relatively lower in the municipalities that experienced this type of change than the rest of the sample during the study time period. 
The positive coefficients for change in population, average income and average population density suggest these values were relatively higher in the municipalities that experienced this type of change.

Figure 17 - Forest to Urban Change Transition

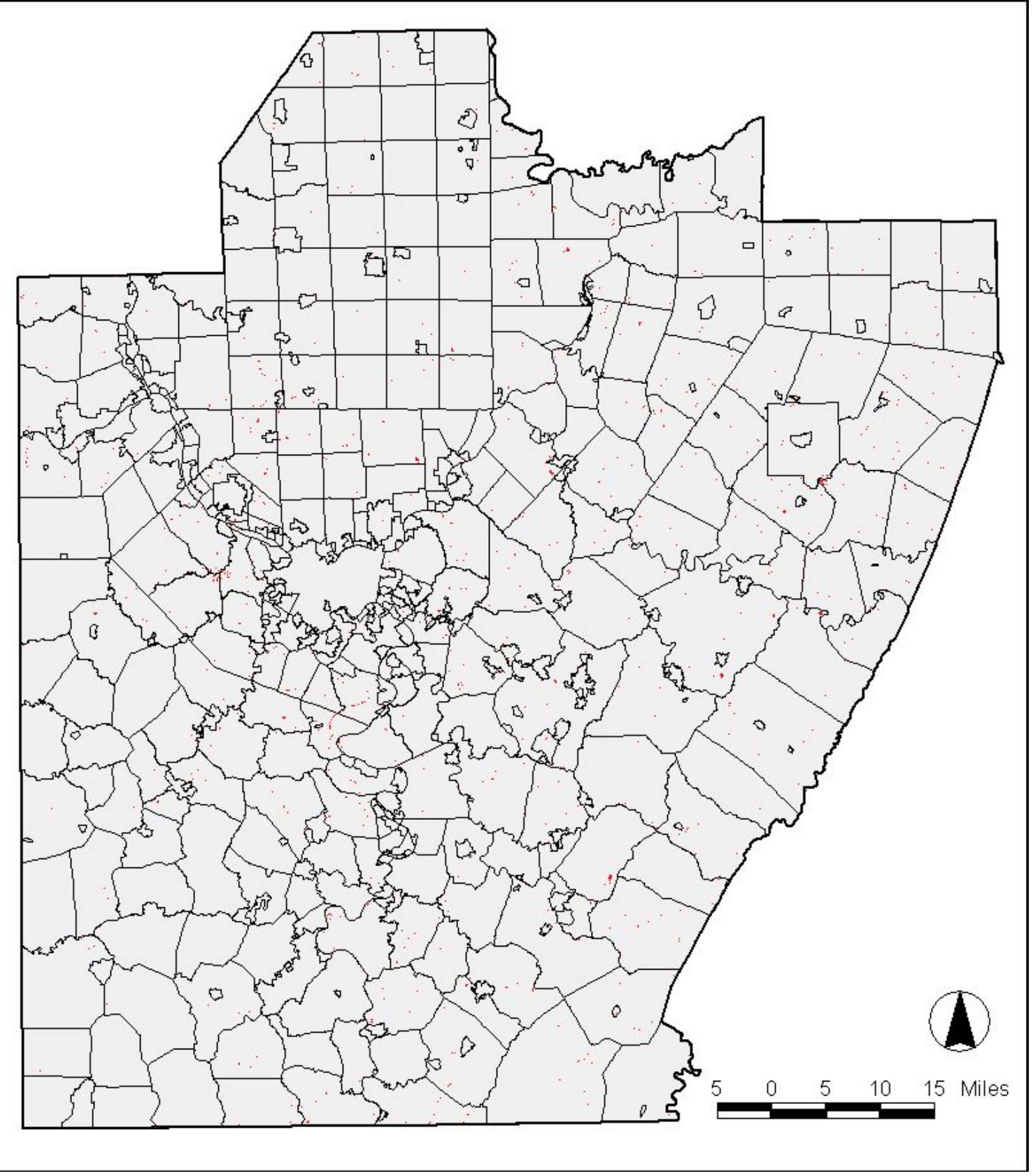


10. Change transition Forest to Residential

Table 22 - Forest to Residential Coefficients

\begin{tabular}{|c|c|c|c|c|c|c|}
\hline Policy & $\begin{array}{c}\text { Comprehensive } \\
\text { Plan }\end{array}$ & Zoning & Subdivision & $\begin{array}{c}\text { Planning } \\
\text { Commission }\end{array}$ & & \\
\hline & 0.14320000 & 0.08210000 & 0.17360000 & -0.03450000 & & \\
\hline \multirow[t]{2}{*}{ Control } & $\begin{array}{l}\text { Percent Existing } \\
\text { Land-use }\end{array}$ & $\begin{array}{c}\text { Average } \\
\text { Population }\end{array}$ & $\begin{array}{l}\text { Change in } \\
\text { Population }\end{array}$ & $\begin{array}{l}\text { Average } \\
\text { Income }\end{array}$ & $\begin{array}{l}\text { Change in } \\
\text { Income }\end{array}$ & $\begin{array}{c}\text { Average } \\
\text { Population } \\
\text { Density }\end{array}$ \\
\hline & -0.02070000 & -0.00000122 & -0.00379000 & 0.00001400 & 0.11610000 & 0.00015700 \\
\hline
\end{tabular}

Policy Variables-

A positive relationship was observed between forest to residential land-use changes and the policy variables comprehensive plan, zoning and subdivision regulation. A negative relationship was observed with the policy variable planning commission. This means that the presence of a comprehensive plan, zoning and subdivision regulation were more likely to be present in municipalities that experienced this kind of land-use change during the study time period, and a planning commission was less likely to be present in these municipalities.

\section{Control Variables-}

The negative coefficient value of the percent existing land-use control variable suggests that the forest to residential land-use change was less likely to occur in those municipalities with larger amounts of the existing land-use during the study time period. The negative coefficient for the average population and change in population control variables suggests that this value is relatively lower in the municipalities that experienced this type of change than the rest of the sample during the study time period. The positive coefficients for average income, change in income and average population 
density suggest these values were relatively higher in the municipalities that experienced this type of change.

Figure 18 - Forest to Residential Change Transition

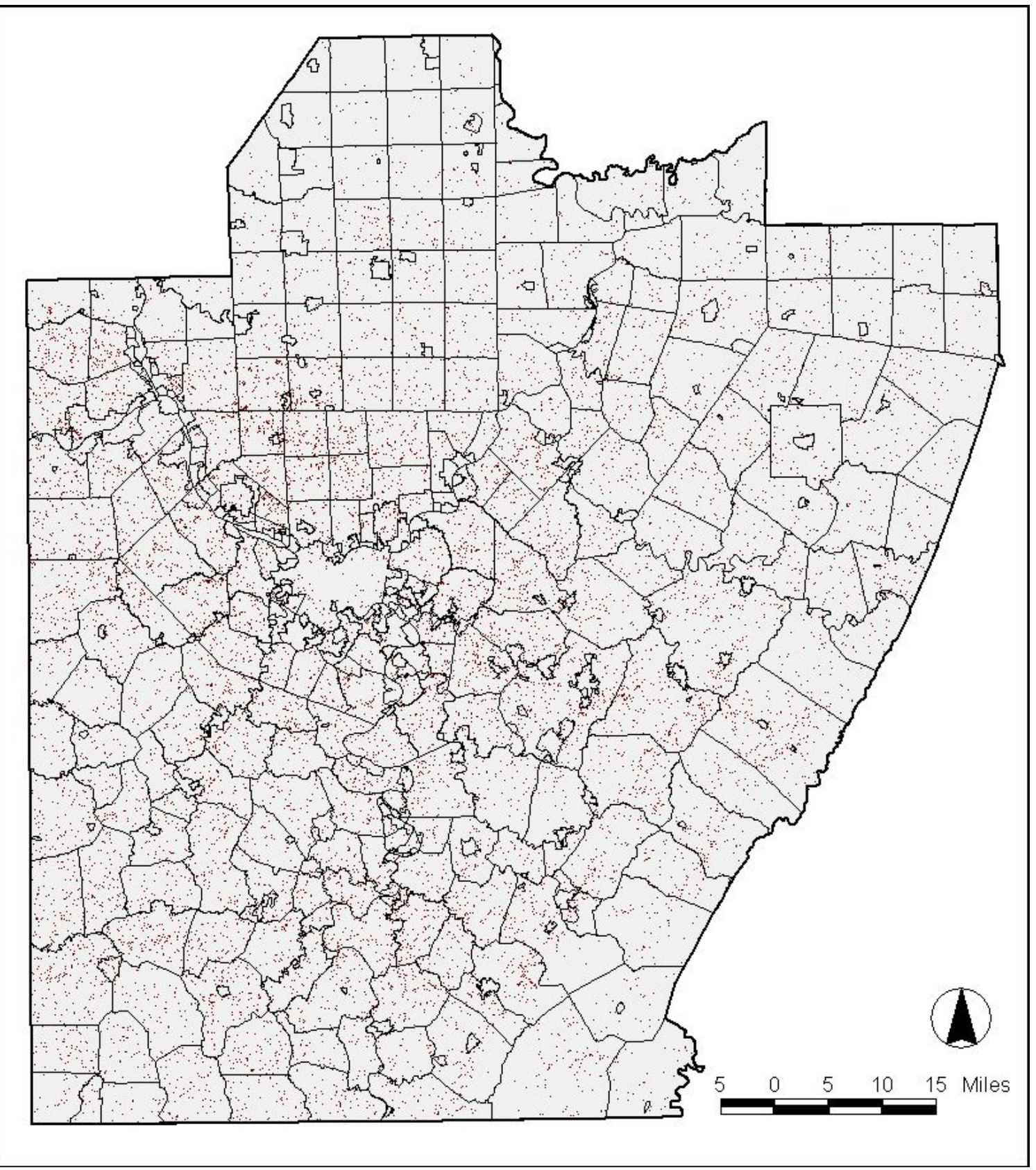


11. Change transition Forest to AgGrass

Table 23 - Forest to AgGrass Coefficients

\begin{tabular}{|c|c|c|c|c|c|c|}
\hline Policy & \begin{tabular}{|c|} 
Comprehensive \\
Plan
\end{tabular} & Zoning & Subdivision & $\begin{array}{c}\text { Planning } \\
\text { Commission }\end{array}$ & & \\
\hline & 0.14250000 & & -0.04380000 & -0.02180000 & & \\
\hline \multirow[t]{2}{*}{ Control } & $\begin{array}{c}\text { Percent Existing } \\
\text { Land-use }\end{array}$ & $\begin{array}{l}\text { Average } \\
\text { Population }\end{array}$ & $\begin{array}{l}\text { Change in } \\
\text { Population }\end{array}$ & $\begin{array}{l}\text { Average } \\
\text { Income }\end{array}$ & $\begin{array}{l}\text { Change in } \\
\text { Income }\end{array}$ & $\begin{array}{l}\text { Average } \\
\text { Population } \\
\text { Density }\end{array}$ \\
\hline & -0.00922000 & 0.00000052 & -0.00589000 & -0.00000089 & 0.03960000 & -0.00016000 \\
\hline
\end{tabular}

Policy Variables-

A positive relationship was observed between forest to AgGrass land-use changes and the policy variable comprehensive plan. A negative relationship was observed with the policy variables subdivision regulation and planning commission. This means that the presence of a comprehensive plan was more likely to be present in municipalities that experienced this kind of land-use change during the study time period, and subdivision regulation and planning commission were less likely to be present in these municipalities. The presence or absence of zoning was not statistically significant with this land-use change transition.

\section{Control Variables-}

The negative coefficient value of the percent existing land-use control variable suggests that the forest to AgGrass land-use change was less likely to occur in those municipalities with larger amounts of the existing land-use during the study time period. The positive coefficient for the average population and change in income control variables suggests that this value is relatively lower in the municipalities that experienced 
this type of change than the rest of the sample during the study time period. The negative coefficients for change in population, average income and average population density suggest these values were relatively lower in the municipalities that experienced this type of change.

\section{Figure 19 - Forest to AgGrass Change Transition}

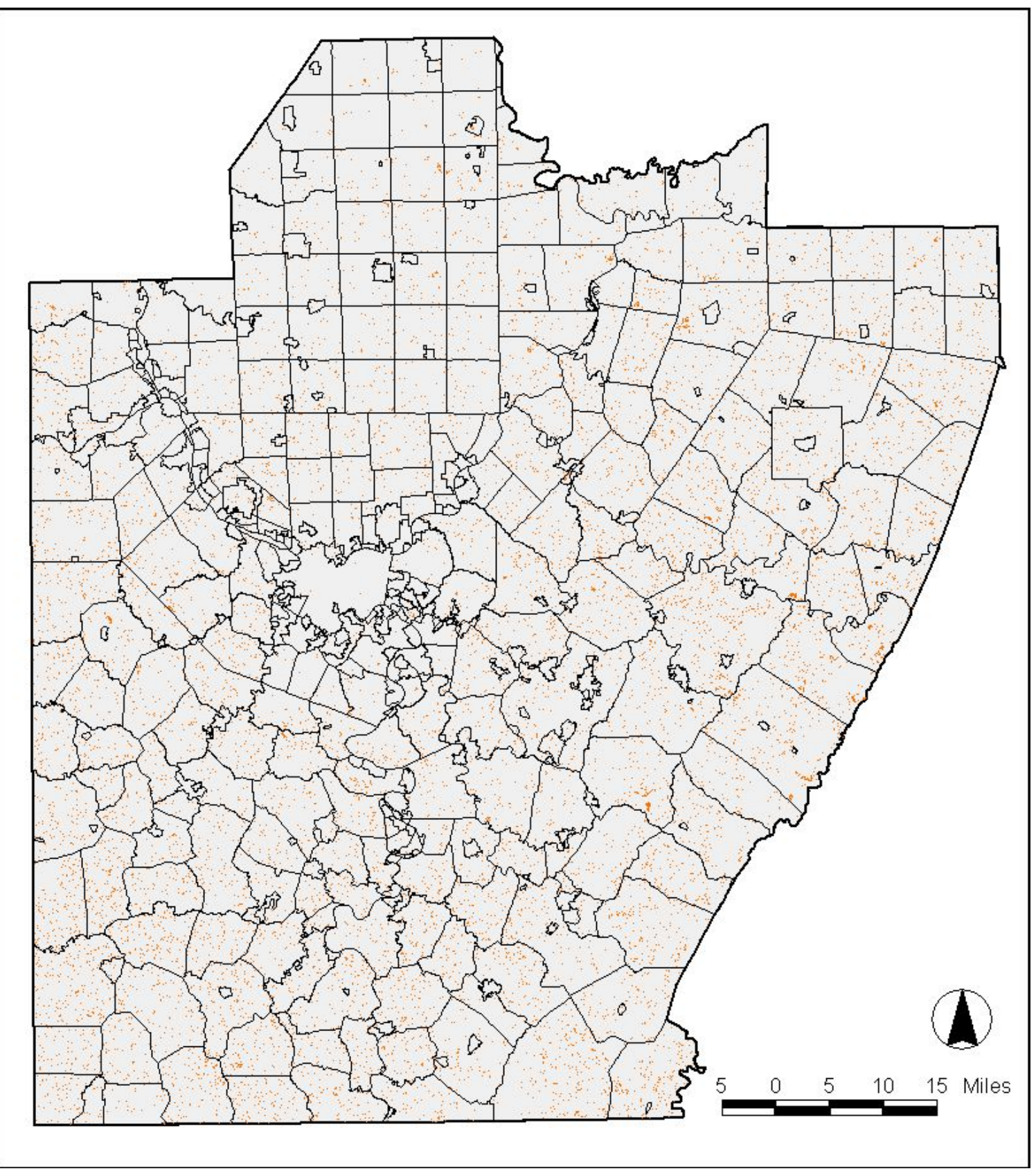


12. Change transition AgGrass to Urban

Table 24 - AgGrass to Urban Coefficients

\begin{tabular}{|c|c|c|c|c|c|c|}
\hline \multirow[t]{2}{*}{ Policy } & $\begin{array}{c}\text { Comprehensive } \\
\text { Plan }\end{array}$ & Zoning & Subdivision & $\begin{array}{c}\text { Planning } \\
\text { Commission }\end{array}$ & & \\
\hline & & 0.18930000 & 0.10750000 & -0.23680000 & & \\
\hline \multirow[t]{2}{*}{ Control } & $\begin{array}{c}\text { Percent Existing } \\
\text { Land-use }\end{array}$ & $\begin{array}{c}\text { Average } \\
\text { Population }\end{array}$ & $\begin{array}{l}\text { Change in } \\
\text { Population }\end{array}$ & $\begin{array}{l}\text { Average } \\
\text { Income }\end{array}$ & $\begin{array}{l}\text { Change in } \\
\text { Income }\end{array}$ & $\begin{array}{c}\text { Average } \\
\text { Population } \\
\text { Density }\end{array}$ \\
\hline & -0.00554000 & 0.00000125 & 0.00885000 & 0.00001100 & -1.01070000 & 0.00018100 \\
\hline
\end{tabular}

Policy Variables-

A positive relationship was observed between AgGrass to urban land-use changes and the policy variables zoning and subdivision regulation. A negative relationship was observed with the policy variable planning commission. This means that zoning and subdivision regulation were more likely to be present in municipalities that experienced this kind of land-use change during the study time period, and a planning commission was less likely to be present in these municipalities. The presence or absence of a comprehensive plan was not statistically significant with this land-use change transition.

\section{Control Variables-}

The negative coefficient value of the percent existing land-use control variable suggests that the AgGrass to urban land-use change was less likely to occur in those municipalities with larger amounts of the existing land-use during the study time period. The positive coefficient for the average population, change in population, average income and average population density control variables suggests that this value is relatively higher in these municipalities that experienced this type of change than the 
rest of the sample during the study time period. The negative coefficient for change in income suggests these values were relatively lower in the municipalities that experienced this type of change.

Figure 20 - AgGrass to Urban Change Transition

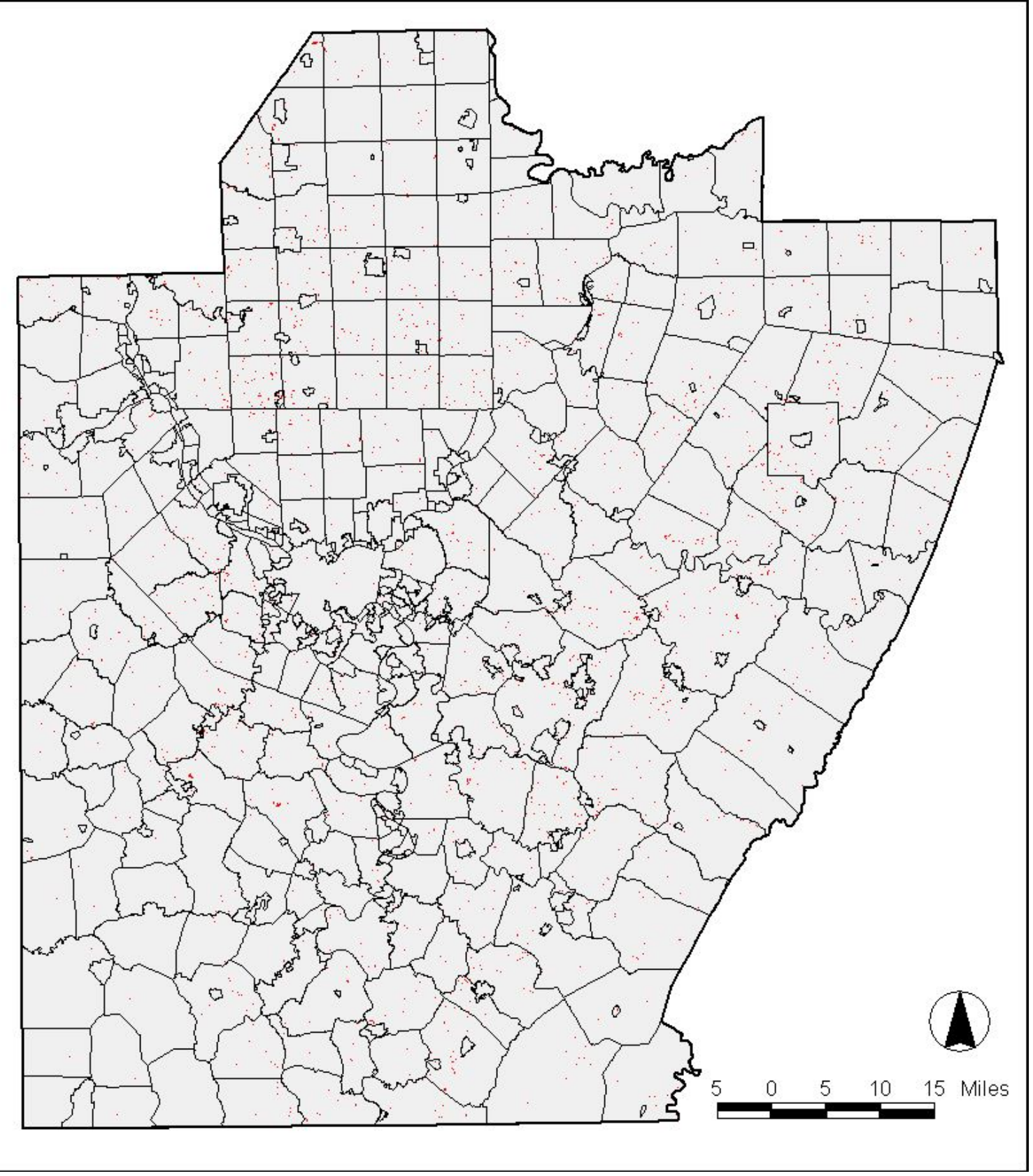


13. Change transition AgGrass to Residential

Table 25 - AgGrass to Residential Coefficients

\begin{tabular}{|c|c|c|c|c|c|c|}
\hline \multirow[t]{2}{*}{ Policy } & \begin{tabular}{|c|} 
Comprehensive \\
Plan
\end{tabular} & Zoning & Subdivision & $\begin{array}{c}\text { Planning } \\
\text { Commission }\end{array}$ & & \\
\hline & 0.08280000 & & 0.22070000 & 0.07430000 & & \\
\hline \multirow[t]{2}{*}{ Control } & $\begin{array}{c}\text { Percent Existing } \\
\text { Land-use }\end{array}$ & $\begin{array}{c}\text { Average } \\
\text { Population }\end{array}$ & $\begin{array}{l}\text { Change in } \\
\text { Population }\end{array}$ & $\begin{array}{l}\text { Average } \\
\text { Income }\end{array}$ & $\begin{array}{l}\text { Change in } \\
\text { Income }\end{array}$ & $\begin{array}{c}\text { Average } \\
\text { Population } \\
\text { Density }\end{array}$ \\
\hline & -0.01080000 & -0.00000153 & -0.00169000 & 0.00001500 & -0.06880000 & 0.00036800 \\
\hline
\end{tabular}

Policy Variables-

A positive relationship was observed between AgGrass to residential landuse changes and the policy variables comprehensive plan, subdivision regulation and planning commission. There were no policy variables that experienced a negative relationship with this kind of land-use change transition. This means that comprehensive plan, subdivision regulation and planning commission were more likely to be present in municipalities that experienced this kind of land-use change during the study time period. The presence or absence of zoning was not statistically significant with this land-use change transition.

\section{Control Variables-}

The negative coefficient value of the percent existing land-use control variable suggests that the AgGrass to residential land-use change was less likely to occur in those municipalities with larger amounts of the existing land-use during the study time period. The negative coefficients for the average population, change in population and change in income control variables suggests that this value is relatively lower in these 
municipalities that experienced this type of change than the rest of the sample during the study time period. The positive coefficient for average income suggests these values were relatively higher in the municipalities that experienced this type of change.

Figure 21 - AgGrass to Residential Change Transition

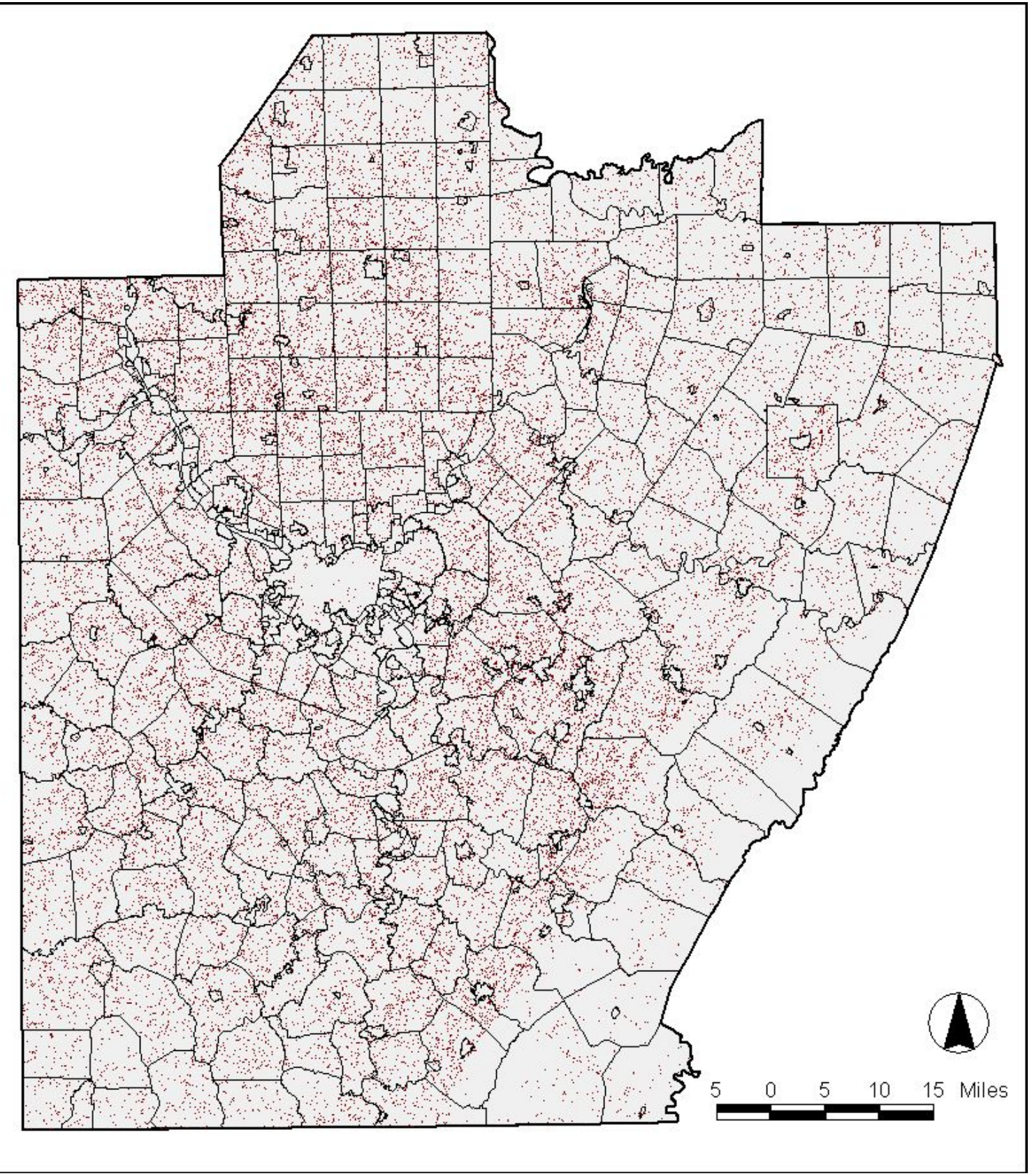


14. Change transition AgGrass to Forest

Table 26 - AgGrass to Forest Coefficients

\begin{tabular}{|c|c|c|c|c|c|c|}
\hline Policy & $\begin{array}{c}\text { Comprehensive } \\
\text { Plan }\end{array}$ & Zoning & Subdivision & \begin{tabular}{|c|} 
Planning \\
Commission
\end{tabular} & & \\
\hline & -0.17020000 & 0.01610000 & 0.02900000 & -0.19920000 & & \\
\hline \multirow[t]{2}{*}{ Control } & $\begin{array}{c}\text { Percent Existing } \\
\text { Land-use }\end{array}$ & $\begin{array}{c}\text { Average } \\
\text { Population }\end{array}$ & $\begin{array}{l}\text { Change in } \\
\text { Population }\end{array}$ & $\begin{array}{l}\text { Average } \\
\text { Income }\end{array}$ & $\begin{array}{l}\text { Change in } \\
\text { Income }\end{array}$ & $\begin{array}{c}\text { Average } \\
\text { Population } \\
\text { Density }\end{array}$ \\
\hline & 0.00777000 & -0.00000588 & 0.00995000 & -0.00000904 & 0.42650000 & 0.00006700 \\
\hline
\end{tabular}

Policy Variables-

A negative relationship was observed between AgGrass to forest land-use changes and the policy variables comprehensive plan and planning commission. A positive relationship was observed with the policy variables zoning and subdivision regulation. This means that comprehensive plan and planning commission were less likely to be present in municipalities that experienced this kind of land-use change during the study time period, and zoning and subdivision were more likely to be present in these municipalities.

\section{Control Variables-}

The positive coefficient value of the percent existing land-use control variable suggests that the AgGrass to forest land-use change was more likely to occur in those municipalities with larger amounts of the existing land-use during the study time period. The negative coefficients for the average population and average income control variables suggests that this value is relatively lower in these municipalities that experienced this type of change than the rest of the sample during the study time period. 
The positive coefficients for change in population, change in income and average population density suggest these values were relatively higher in the municipalities that experienced this type of change.

Figure 22 - AgGrass to Forest Change Transition

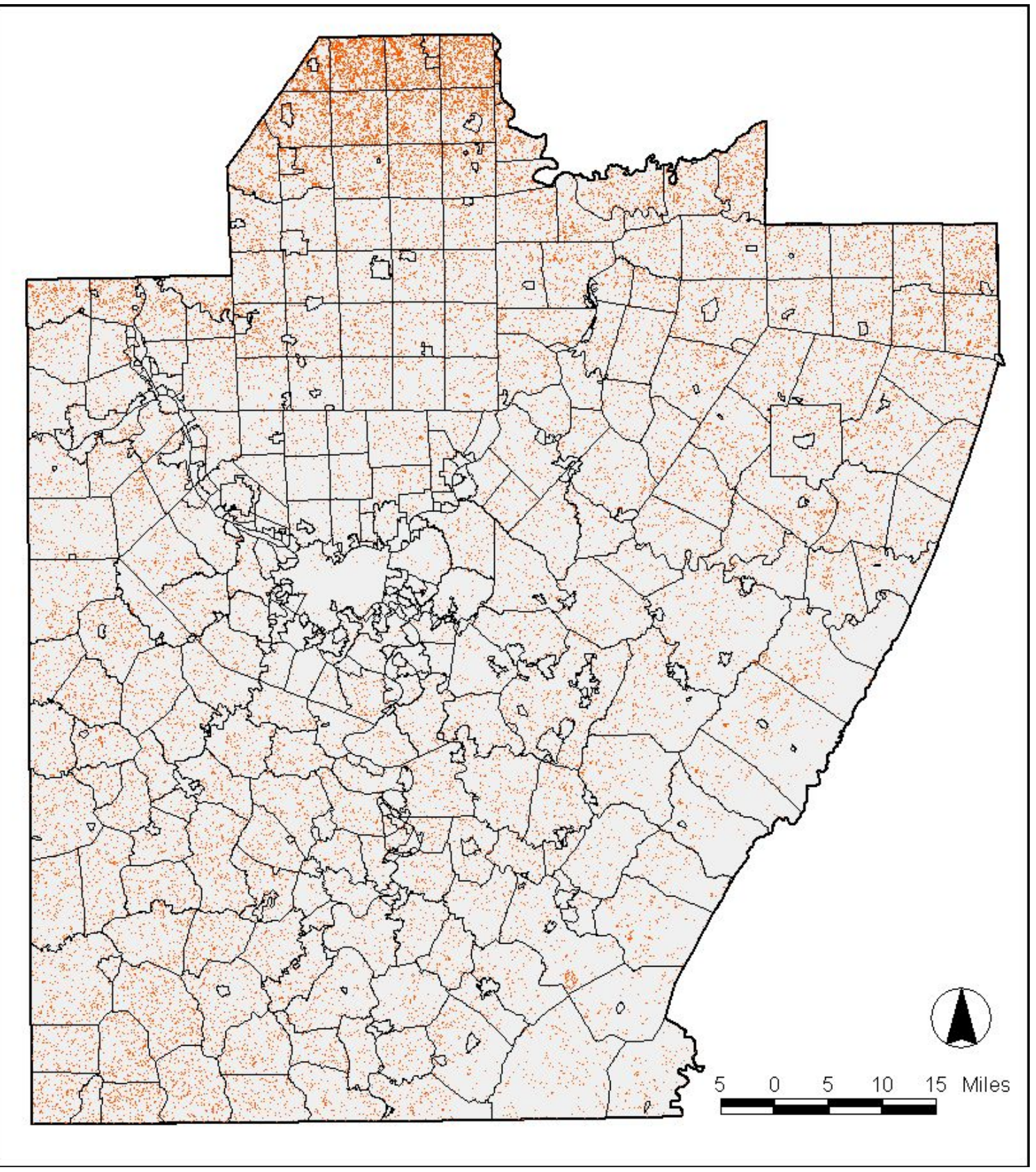




\section{Discussion}

Tables 27, 28, 29, and 30 below contain the same values as Table 12, but each ranks the coefficient significance level of each policy from highest to lowest regarding each land-use change transition. Using these tables together, each transition can be analyzed. The two most obvious relationships are, 1) the municipalities that experienced land-use change from forest to any of the other three possible land-uses were highly likely to have a comprehensive plan (Table 27), and 2) that subdivision regulations were not statistically significant in those municipalities that experienced land-use change from residential to any of the other possible land-uses (Table 29). The remainder of this discussion will examine the land-use change transitions represented from forest to urban, residential and AgGrass land-uses, and AgGrass to urban and AgGrass to residential land-uses. These transitions were chosen because they best represent urbanizing areas. The change transition from forest to other land-uses exhibits several interesting relationships. Forest to urban and forest to residential land-use changes represent the land-use transition from a less-developed to a developing land-use, while forest to AgGrass can represent a transitional land-use from a less-developed to a developing landuse; the assumption being that agricultural practices in the study area are declining as the built-environment is increasing.

The coefficients in Tables 27, 28, 29 and 30 represents the significance of these changes. Forest to urban represents the most extreme land-use change. The likelihood of a comprehensive plan and zoning and less likelihood of subdivision regulation and a planning commission is an interesting finding; however, the fact that the positive coefficient for zoning is the most likely (highest value in Table 28) and the negative 
Table 27 - Comprehensive Plan Ranked Coefficients

\begin{tabular}{|l|c|}
\hline \multicolumn{1}{|c|}{$\begin{array}{c}\text { Land-use Change } \\
\text { Transition }\end{array}$} & $\begin{array}{c}\text { Comprehensive } \\
\text { Plan }\end{array}$ \\
\hline Forest to Residential & 0.14320000 \\
Forest to AgGrass & 0.14250000 \\
\hline Forest to Urban & 0.13080000 \\
Residential to Urban & 0.11600000 \\
AgGrass to Residential & 0.08280000 \\
Less-developed to Developed & 0.07700000 \\
Residential to AgGrass & 0.05260000 \\
Urban to Residential & 0.02130000 \\
Urban to AgGrass & -0.13200000 \\
Developed to Less-developed & -0.13950000 \\
Urban to Forest & -0.16900000 \\
AgGrass to Forest & -0.17020000 \\
Residential to Forest & -0.18080000 \\
\hline AgGrass to Urban & \\
\hline
\end{tabular}

Table 29 - Subdivision Regulation Ranked Coefficients

\begin{tabular}{|l|c|}
\hline \multicolumn{1}{|c|}{$\begin{array}{c}\text { Land-use Change } \\
\text { Transition }\end{array}$} & Subdivision \\
\hline AgGrass to Residential & 0.22070000 \\
Urban to Residential & 0.18830000 \\
Forest to Residential & 0.17360000 \\
\hline Urban to AgGrass & 0.16640000 \\
Less-developed to Developed & 0.13430000 \\
AgGrass to Urban & 0.10750000 \\
AgGrass to Forest & 0.02900000 \\
Developed to Less-developed & 0.02640000 \\
Forest to AgGrass & -0.04380000 \\
Forest to Urban & -0.10330000 \\
Urban to Forest & -0.14320000 \\
\hline Residential to Urban & \\
Residential to Forest & \\
Residential to AgGrass & \\
\hline
\end{tabular}

Table 28 - Zoning Regulation Ranked Coefficients

\begin{tabular}{|l|c|}
\hline \multicolumn{1}{|c|}{$\begin{array}{c}\text { Land-use Change } \\
\text { Transition }\end{array}$} & Zoning \\
\hline Forest to Urban & 0.48910000 \\
Residential to Urban & 0.34510000 \\
AgGrass to Urban & 0.18930000 \\
\hline Urban to Residential & 0.12950000 \\
\hline Urban to Forest & 0.09740000 \\
Forest to Residential & 0.08210000 \\
AgGrass to Forest & 0.01610000 \\
\hline Less-developed to Developed & -0.05630000 \\
\hline Residential to AgGrass & -0.05910000 \\
\hline Urban to AgGrass & -0.15400000 \\
\hline Developed to Less-developed & -0.20540000 \\
\hline Residential to Forest & -0.27320000 \\
\hline Forest to AgGrass & \\
AggGrass to Residential & \\
\hline
\end{tabular}

Table 30 - Planning Commission Ranked Coefficients

\begin{tabular}{|l|c|}
\hline \multicolumn{1}{|c|}{$\begin{array}{c}\text { Land-use Change } \\
\text { Transition }\end{array}$} & $\begin{array}{c}\text { Planning } \\
\text { Commission }\end{array}$ \\
\hline Residential to Forest & 0.09570000 \\
\hline Less-developed to Developed & 0.07940000 \\
\hline AgGrass to Residential & 0.07430000 \\
\hline Urban to Residential & 0.04380000 \\
\hline Forest to AgGrass & -0.02180000 \\
\hline Forest to Residential & -0.03450000 \\
Developed to Less-developed & -0.06060000 \\
\hline Residential to AgGrass & -0.11430000 \\
\hline Urban to AgGrass & -0.14290000 \\
AgGrass to Forest & -0.19920000 \\
\hline Residential to Urban & -0.20510000 \\
\hline AgGrass to Urban & -0.23680000 \\
\hline Forest to Urban & -0.56190000 \\
\hline Urban to Forest & \\
\hline
\end{tabular}


coefficient for a planning commission the least likely (lowest value in Table 30) is particularly revealing. Revealing because a comprehensive plan is a guidance document that is prepared to serve an approximate 10 -year period and is sporadically updated nor authoritative in most instances. Yet a planning commission is a group of local citizens that meet on a monthly basis to discuss and review proposed land-use issues within their jurisdiction and have some authority to approve or deny land-use propositions.

Therefore, the data suggests that those municipalities that desire to maintain forested land-use should form a planning commission to adhere to the recommendations made in their comprehensive plans.

Also interesting about the forest to- land-use change is that when the four landuse categories (urban, residential, forest, and AgGrass) were recoded into two land-use change transitions (developed to less-developed and less-developed to developed), the relationships that existed with the Forest to Urban transition that are explained above are no longer the same when combined. This change in statistical significance could be attributed to the modified areal unit problem (MAUP). The MAUP refers to the fact that the results of statistical data will be different depending on the zoning system used to report aggregated data. Therefore, it is very possible that the aggregating of the values within the units resulted in different coefficient values than expected and is the cause of the discrepancy noted above (Rogerson, 2004).

The change transition from AgGrass to other developed land-uses also exhibits several interesting relationships. For example, the most significant coefficient in Table 29, subdivision ranked coefficients, is AgGrass to residential and the relationship between AgGrass to urban is also positive with this planning tool. This is unlike the 
relationships shown in Table 27 , comprehensive plan ranked coefficients, and Table 30, planning commission ranked coefficients. There are positive relationships with AgGrass to residential with both comprehensive plans and planning commissions; a statistically insignificant relationship with AgGrass to urban with a comprehensive plan; and a negative relationship with AgGrass to urban with planning commission. Like the relationships shared with comprehensive plan, zoning also had one positive and one statistically insignificant relationship shown, but the nature of the relationships was reversed; where AgGrass to Urban was positive and AgGrass to residential was not significant. These are significant findings that warrant further research in order to determine why these relationships exist and to identify what and what kind of local dynamic occurs that causes these results. 


\section{Municipalities}

This section shifts the focus from the coefficients of the global statistic results of the logistic regression to individual municipalities that experienced particular types of land-use change. What follows is a descriptive analysis of the policy variables, percentage of land-use change, and percentage of change in the control variables for a selection of the sample that fit certain criteria. It should be noted here that this research is not intended to advocate the adoption, use or application of one particular land-use tool over another, the intent of the research is clearly stated - to analyze the relationship between local planning policy and land-use change in the Pittsburgh metropolitan region during the study period.

While each and every one of these municipalities have their own story to be told, the criteria used for the characterization of municipalities in this section are the 20 municipalities over 5 square miles in area that experienced the most land-use changes from; forest to 'developed', AgGrass to 'developed', and residential to urban.

The decision to use municipalities over 5 square miles in area was made arbitrarily as a control for municipal size and to ensure that an adequate amount of pixels were represented in order to detect the land-use change transitions. For each of the three transitions discussed there is first a graph that shows the 20 municipalities over 5 square miles that experienced the greatest proportional land-use change transition ranked in order at the top of the graph from most to least going left to right (secondary $\mathrm{x}$ axis); the number of planning tools enacted in each municipality are along the bottom (primary $\mathrm{x}$ axis); and the percent change in control and policy variables are shown on the sides (y axis). Following the graph is a table that ranks the top 20 municipalities in the same 
manner as the preceding graph and displays the real values for each variable in the graph. Last is a map that identifies all of the municipalities characterized in this section marking which municipality experienced the greatest degree of the three land-use change transitions discussed.

\section{Forest to development}

The municipalities that experienced the most forest to urban or residential change were existing urbanized or suburban areas. The proportional percent change from forest to urban was not large in any of the top 20 municipalities over 5 square miles (Figure 23). The change ranged from a high of $3 \%$ to a low of $1 \%$ (Table 31 ).

Forest to residential change was much larger with a high of $29 \%$ and a low of $2 \%$. Interestingly, the two municipalities that experienced the most forest to residential change were Mount Lebanon (29\%) and Bethel Park (23\%). These municipalities also experienced the least amount of population and income change of the 20 municipalities during the study period, both with incomes rising slightly and populations actually dropping. Both municipalities had all four planning tools enacted. Two other municipalities that are on this list that have zero planning tools are Manor Township and Mercer Township. Both of these municipalities experienced loss of forested land to urban land-uses (Figure 23) and both surround smaller, urbanized boroughs (Ford City, Ford Cliff and Manorville Boroughs near Manor Township, and Harrisonville Borough near Mercer Township). These townships are candidates for continued development and should adopt some, if not all, of the planning tools listed here to ensure local control. 


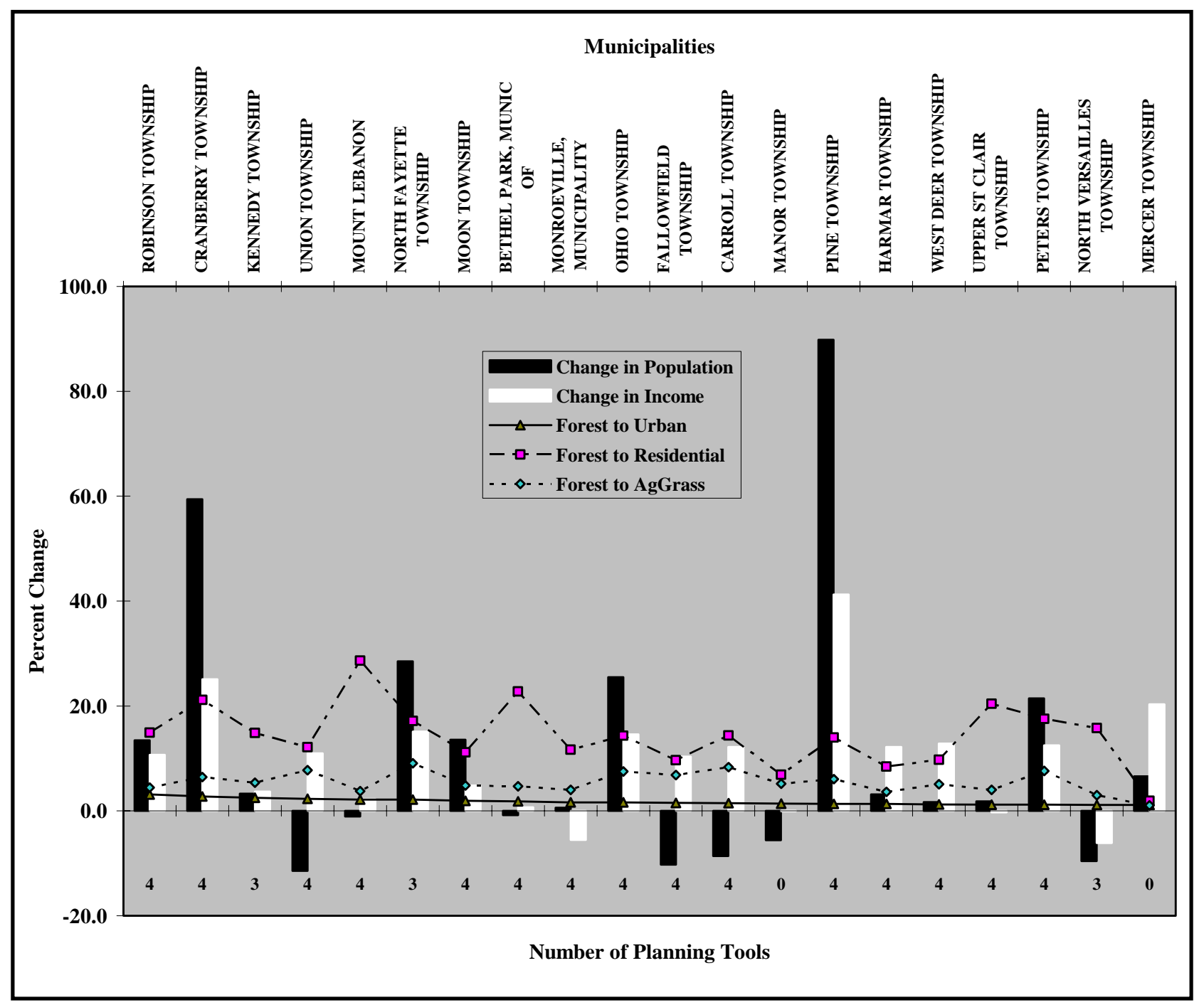

While the forest to AgGrass class is not considered a 'from less-developed to developed' land-use change, it is an indicator of a direction of change from the most extreme less-developed land-use change (forest) to a more developed land-use. This is because it is assumed that during this time period within the study area the clearing of forest is less anticipated to be for agricultural activity and more likely due to residential or urban development. Interestingly, of the 20 municipalities discussed in this group, all 
of the proportional change from forest to AgGrass fell between both the forest to urban

change and the forest to residential change, as shown in Figure 23 above.

\section{Table 31 - Top 20 municipalities greater than 5 square miles in area that experienced from Forest to 'Development'}

\begin{tabular}{|c|c|c|c|c|c|c|c|c|c|c|c|c|}
\hline County & Municipality & $\begin{array}{l}\text { Square } \\
\text { Miles }\end{array}$ & $\begin{array}{c}\% \\
\text { Change } \\
\text { Pop }\end{array}$ & $\begin{array}{c}\% \\
\text { Change } \\
\text { Income }\end{array}$ & $\begin{array}{c}\% \\
\text { Forest- } \\
\text { Urban }\end{array}$ & $\begin{array}{c}\% \\
\text { Forest- } \\
\text { Res. }\end{array}$ & $\begin{array}{c}\% \\
\text { Forest- } \\
\text { AgGrass }\end{array}$ & $\begin{array}{l}\text { Comp } \\
\text { Plan }\end{array}$ & Zoning & $\begin{array}{c}\text { Sub- } \\
\text { division }\end{array}$ & $\begin{array}{l}\text { Planning } \\
\text { Comm. }\end{array}$ & $\begin{array}{l}\text { Tools } \\
\text { Total }\end{array}$ \\
\hline ALLEGHENY & ROBINSON TOWNSHIP & 15 & 13 & 11 & 3 & 15 & 4 & 1 & 1 & 1 & 1 & 4 \\
\hline BUTLER & CRANBERRY TOWNSHIP & 23 & 59 & 25 & 3 & 21 & 6 & 1 & 1 & 1 & 1 & 4 \\
\hline ALLEGHENY & KENNEDY TOWNSHIP & 6 & 3 & 4 & 3 & 15 & 5 & 0 & 1 & 1 & 1 & 3 \\
\hline WASHINGTON & UNION TOWNSHIP & 16 & -11 & 11 & 2 & 12 & 8 & 1 & 1 & 1 & 1 & 4 \\
\hline ALLEGHENY & MOUNT LEBANON & 6 & -1 & 2 & 2 & 29 & 4 & 1 & 1 & 1 & 1 & 4 \\
\hline ALLEGHENY & NORTH FAYETTE TOWNSHIP & 25 & 28 & 15 & 2 & 17 & 9 & 0 & 1 & 1 & 1 & 3 \\
\hline ALLEGHENY & MOON TOWNSHIP & 24 & 14 & 5 & 2 & 11 & 5 & 1 & 1 & 1 & 1 & 4 \\
\hline ALLEGHENY & BETHEL PARK, MUNIC OF & 12 & -1 & 1 & 2 & 23 & 5 & 1 & 1 & 1 & 1 & 4 \\
\hline ALLEGHENY & $\begin{array}{l}\text { MONROEVILLE, } \\
\text { MUNICIPALITY }\end{array}$ & 20 & 1 & -6 & 2 & 12 & 4 & 1 & 1 & 1 & 1 & 4 \\
\hline ALLEGHENY & OHIO TOWNSHIP & 7 & 25 & 15 & 2 & 14 & 8 & 1 & 1 & 1 & 1 & 4 \\
\hline WASHINGTON & FALLOWFIELD TOWNSHIP & 21 & -10 & 10 & 2 & 10 & 7 & 1 & 1 & 1 & 1 & 4 \\
\hline WASHINGTON & CARROLL TOWNSHIP & 14 & -9 & 12 & 1 & 14 & 8 & 1 & 1 & 1 & 1 & 4 \\
\hline ARMSTRONG & MANOR TOWNSHIP & 17 & -6 & 0 & 1 & 7 & 5 & 0 & 0 & 0 & 0 & 0 \\
\hline ALLEGHENY & PINE TOWNSHIP & 17 & 90 & 41 & 1 & 14 & 6 & 1 & 1 & 1 & 1 & 4 \\
\hline ALLEGHENY & HARMAR TOWNSHIP & 6 & 3 & 12 & 1 & 8 & 4 & 1 & 1 & 1 & 1 & 4 \\
\hline ALLEGHENY & WEST DEER TOWNSHIP & 29 & 2 & 13 & 1 & 10 & 5 & 1 & 1 & 1 & 1 & 4 \\
\hline ALLEGHENY & UPPER ST CLAIR TOWNSHIP & 10 & 2 & 0 & 1 & 20 & 4 & 1 & 1 & 1 & 1 & 4 \\
\hline WASHINGTON & PETERS TOWNSHIP & 20 & 21 & 12 & 1 & 18 & 8 & 1 & 1 & 1 & 1 & 4 \\
\hline ALLEGHENY & TOWNSHIP & 8 & -10 & -6 & 1 & 16 & 3 & 0 & 1 & 1 & 1 & 3 \\
\hline BUTLER & MERCER TOWNSHIP & 13 & 7 & 20 & 1 & 2 & 1 & 0 & 0 & 0 & 0 & 0 \\
\hline
\end{tabular}

\section{AgGrass to development}

The municipalities that experienced AgGrass to urban or residential change were also existing urbanized or suburban areas. Similar to the municipalities that experienced forest to urban land-use change described above, the proportional percent change from AgGrass to urban was not large in any of the top 20 municipalities over 5 square miles. The change ranged from a high of $7 \%$ to a low of $2 \%$ (Figure 24 and Table 32). AgGrass to residential proportional percent change was much higher with a high of $59 \%$ and a low of $15 \%$. The municipality that experienced the most AgGrass to residential change was 
North Versailles, which also had experienced the highest losses of population and income during of the 20 municipalities during the study period. North Versailles had three planning tools enacted (Figure 24).

Fifteen (75\%) of municipalities that experienced AgGrass to developing land-use changes (represented by AgGrass to urban and AgGrass to residential) had all four planning tools, and three municipalities (15\%) had three planning tools.

Figure 24 - Top 20 municipalities greater than 5 square miles in area that experienced from AgGrass to 'Development'

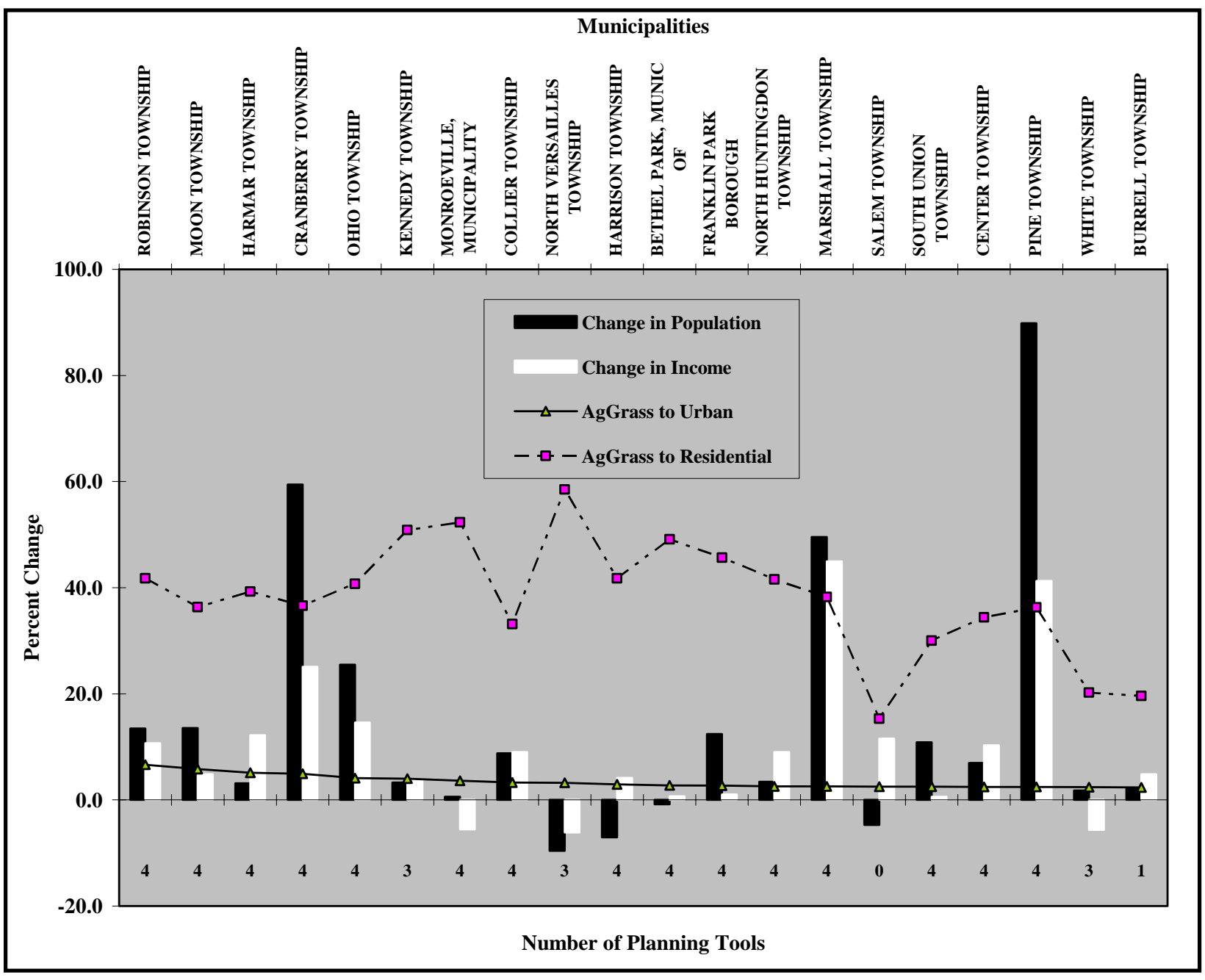


The two remaining municipalities (10\%) in this group were Salem Township.

with zero planning tools and Burrell Township. with one planning tool (Figure 24).

Salem and Burrell Townships were the $15^{\text {th }}$ and $20^{\text {th }}$ ranked municipalities in this group, respectively. Table 32 also shows that these two municipalities had the least amount of AgGrass to residential land-use change of the group. Interestingly, Salem Township had a population loss but income gain during the study period. Together these values identify Salem Township as an area that experienced both a socio-economic and physical transformation during the study period. Also, the fact that Salem Township did not have any planning tools enacted suggests that this area many have experienced locally undesirable development patterns during this time. Table 32 - Top 20 municipalities greater than 5 square miles in area that experienced from
AgGrass to 'Development'

\begin{tabular}{|c|c|c|c|c|c|c|c|c|c|c|c|}
\hline County & Municipality & $\begin{array}{l}\text { Square } \\
\text { Miles }\end{array}$ & $\begin{array}{c}\% \\
\text { Change } \\
\text { Pop }\end{array}$ & $\begin{array}{c}\% \\
\text { Change } \\
\text { Income }\end{array}$ & $\begin{array}{c}\% \\
\text { AgGrass- } \\
\text { Urban }\end{array}$ & $\begin{array}{c}\% \\
\text { AgGrass- } \\
\text { Res }\end{array}$ & $\begin{array}{l}\text { Comp } \\
\text { Plan }\end{array}$ & Zoning & $\begin{array}{c}\text { Sub- } \\
\text { division }\end{array}$ & $\begin{array}{l}\text { Planning } \\
\text { Comm. }\end{array}$ & $\begin{array}{l}\text { Tools } \\
\text { Total }\end{array}$ \\
\hline ALLEGHENY & ROBINSON TOWNSHIP & 15 & 13 & 11 & 7 & 42 & 1 & 1 & 1 & 1 & 4 \\
\hline ALLEGHENY & MOON TOWNSHIP & 24 & 14 & 5 & 6 & 36 & 1 & 1 & 1 & 1 & 4 \\
\hline ALLEGHENY & HARMAR TOWNSHIP & 6 & 3 & 12 & 5 & 39 & 1 & 1 & 1 & 1 & 4 \\
\hline BUTLER & CRANBERRY TOWNSHIP & 23 & 59 & 25 & 5 & 37 & 1 & 1 & 1 & 1 & 4 \\
\hline ALLEGHENY & OHIO TOWNSHIP & 7 & 25 & 15 & 4 & 41 & 1 & 1 & 1 & 1 & 4 \\
\hline ALLEGHENY & KENNEDY TOWNSHIP & 6 & 3 & 4 & 4 & 51 & 0 & 1 & 1 & 1 & 3 \\
\hline ALLEGHENY & MONROEVILLE, MUNICIPALITY & 20 & 1 & -6 & 4 & 52 & 1 & 1 & 1 & 1 & 4 \\
\hline ALLEGHENY & COLLIER TOWNSHIP & 14 & 9 & 9 & 3 & 33 & 1 & 1 & 1 & 1 & 4 \\
\hline ALLEGHENY & $\begin{array}{l}\text { NORTH VERSAILLES } \\
\text { TOWNSHIP }\end{array}$ & 8 & -10 & -6 & 3 & 59 & 0 & 1 & 1 & 1 & 3 \\
\hline ALLEGHENY & HARRISON TOWNSHIP & 8 & -7 & 4 & 3 & 42 & 1 & 1 & 1 & 1 & 4 \\
\hline ALLEGHENY & BETHEL PARK, MUNIC OF & 12 & -1 & 1 & 3 & 49 & 1 & 1 & 1 & 1 & 4 \\
\hline ALLEGHENY & FRANKLIN PARK BOROUGH & 13 & 12 & 1 & 3 & 46 & 1 & 1 & 1 & 1 & 4 \\
\hline WESTMORELAND & TOWNSHIP & 27 & 3 & 9 & 3 & 42 & 1 & 1 & 1 & 1 & 4 \\
\hline ALLEGHENY & MARSHALL TOWNSHIP & 15 & 50 & 45 & 3 & 38 & 1 & 1 & 1 & 1 & 4 \\
\hline WESTMORELAND & SALEM TOWNSHIP & 48 & -5 & 12 & 2 & 15 & 0 & 0 & 0 & 0 & 0 \\
\hline FAYETTE & SOUTH UNION TOWNSHIP & 17 & 11 & 1 & 2 & 30 & 1 & 1 & 1 & 1 & 4 \\
\hline BEAVER & CENTER TOWNSHIP & 16 & 7 & 10 & 2 & 34 & 1 & 1 & 1 & 1 & 4 \\
\hline ALLEGHENY & PINE TOWNSHIP & 17 & 90 & 41 & 2 & 36 & 1 & 1 & 1 & 1 & 4 \\
\hline INDIANA & WHITE TOWNSHIP & 43 & 2 & -6 & 2 & 20 & 1 & 0 & 1 & 1 & 3 \\
\hline INDIANA & BURRELL TOWNSHIP & 25 & 2 & 5 & 2 & 20 & 1 & 0 & 0 & 0 & 1 \\
\hline
\end{tabular}




\section{Residential to urban}

Figure 25 graphs the top 20 municipalities greater than square miles that experienced residential to urban land-use change in a slight different manner than the previous two graphs. The addition of a secondary y-axis on the right side of the graph represents the percent change in residential to urban land-use, and the primary y-axis on the left represents only the percent change of the control variables.

Figure 25 - Top 20 municipalities greater than 5 square miles in area that experienced from Residential to Urban

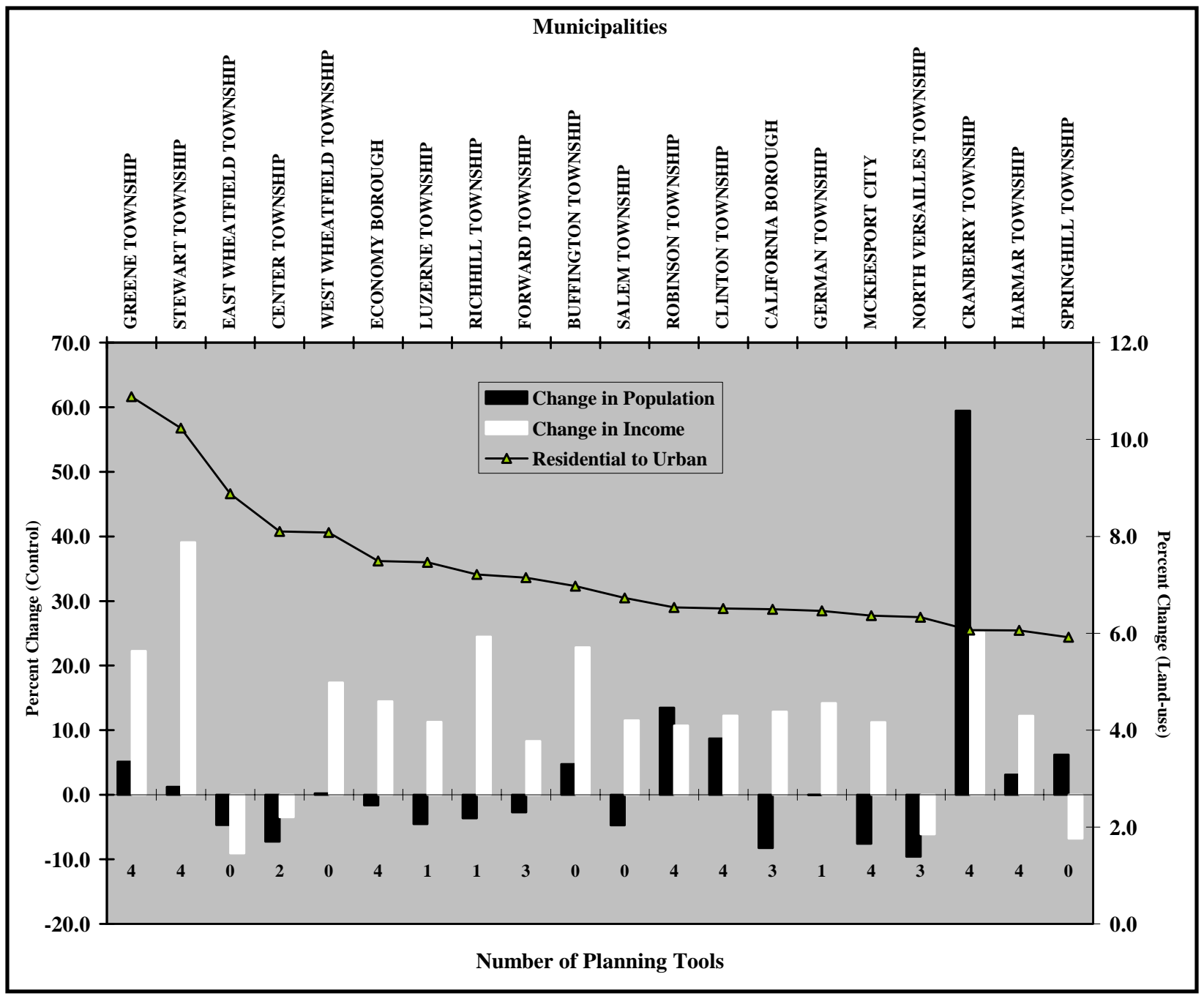


This variation in display was performed because there is only one land-use change shown and because the addition of the second y-axis depicts the percent land-use change more clearly in relation to the control variables.

Of the residential to urban group, four municipalities (20\%) exhibited negative changes in income, and ten municipalities (50\%) exhibited negative changes in population. Nine of these municipalities (45\%) experienced population gains with one municipality (German Township) showing zero change in population (Table 33). The majority of municipalities experienced much higher rates of income change as opposed to population change.

\section{Table 33 - Top 20 municipalities greater than 5 square miles in area that experienced from Residential to Urban}

\begin{tabular}{|c|c|c|c|c|c|c|c|c|c|c|}
\hline County & Municipality & $\begin{array}{l}\text { Square } \\
\text { Miles }\end{array}$ & $\begin{array}{c}\text { Change } \\
\text { Pop }\end{array}$ & $\begin{array}{l}\text { Change } \\
\text { Income }\end{array}$ & $\begin{array}{l}\text { Res- } \\
\text { Urban }\end{array}$ & $\begin{array}{l}\text { Comp } \\
\text { Plan }\end{array}$ & Zoning & Subdiv & $\begin{array}{l}\text { Planning } \\
\text { Comm }\end{array}$ & $\begin{array}{l}\text { Tools } \\
\text { Total }\end{array}$ \\
\hline BEAVER & GREENE TOWNSHIP & 26 & 5 & 22 & 11 & 1 & 1 & 1 & 1 & 4 \\
\hline FAYETTE & STEWART TOWNSHIP & 51 & 1 & 39 & 10 & 1 & 1 & 1 & 1 & 4 \\
\hline INDIANA & $\begin{array}{l}\text { EAST WHEATFIELD } \\
\text { TOWNSHIP }\end{array}$ & 27 & -5 & -9 & 9 & 0 & 0 & 0 & 0 & 0 \\
\hline INDIANA & CENTER TOWNSHIP & 40 & -7 & -3 & 8 & 1 & 0 & 0 & 1 & 2 \\
\hline INDIANA & $\begin{array}{l}\text { WEST WHEATFIELD } \\
\text { TOWNSHIP }\end{array}$ & 32 & 0 & 17 & 8 & 0 & 0 & 0 & 0 & 0 \\
\hline BEAVER & ECONOMY BOROUGH & 18 & -2 & 14 & 7 & 1 & 1 & 1 & 1 & 4 \\
\hline FAYETTE & LUZERNE TOWNSHIP & 31 & -5 & 11 & 7 & 1 & 0 & 0 & 0 & 1 \\
\hline GREENE & RICHHILL TOWNSHIP & 56 & -4 & 24 & 7 & 0 & 0 & 1 & 0 & 1 \\
\hline ALLEGHENY & FORWARD TOWNSHIP & 20 & -3 & 8 & 7 & 0 & 1 & 1 & 1 & 3 \\
\hline INDIANA & BUFFINGTON TOWNSHIP & 31 & 5 & 23 & 7 & 0 & 0 & 0 & 0 & 0 \\
\hline WESTMORELAND & SALEM TOWNSHIP & 48 & -5 & 12 & 7 & 0 & 0 & 0 & 0 & 0 \\
\hline ALLEGHENY & ROBINSON TOWNSHIP & 15 & 13 & 11 & 7 & 1 & 1 & 1 & 1 & 4 \\
\hline BUTLER & CLINTON TOWNSHIP & 24 & 9 & 12 & 7 & 1 & 1 & 1 & 1 & 4 \\
\hline WASHINGTON & CALIFORNIA BOROUGH & 11 & -8 & 13 & 6 & 1 & 1 & 1 & 0 & 3 \\
\hline FAYETTE & GERMAN TOWNSHIP & 34 & 0 & 14 & 6 & 1 & 0 & 0 & 0 & 1 \\
\hline ALLEGHENY & MCKEESPORT CITY & 5 & -8 & 11 & 6 & 1 & 1 & 1 & 1 & 4 \\
\hline ALLEGHENY & TOWNSHIP & 8 & -10 & -6 & 6 & 0 & 1 & 1 & 1 & 3 \\
\hline BUTLER & CRANBERRY TOWNSHIP & 23 & 59 & 25 & 6 & 1 & 1 & 1 & 1 & 4 \\
\hline ALLEGHENY & HARMAR TOWNSHIP & 6 & 3 & 12 & 6 & 1 & 1 & 1 & 1 & 4 \\
\hline FAYETTE & SPRINGHILL TOWNSHIP & 34 & 6 & -7 & 6 & 0 & 0 & 0 & 0 & 0 \\
\hline
\end{tabular}


The most notable exception to this observation is Cranberry Township. Cranberry Township ranked $18^{\text {th }}$ in this group and experienced a $60 \%$ increase in population and a $25 \%$ increase in income during the study period. Cranberry Township also had all four of the planning tools enacted. It should also be noted that Cranberry Township also ranked $2^{\text {nd }}$ among the forest to development group and $4^{\text {th }}$ among the AgGrass to development group. This data suggests that Cranberry Township developed at a disproportional rate than other municipalities in the study area and that it has managed this growth with local control due to its adoption of all four planning tools.

Unlike the forest to developed and AgGrass to developed municipalities, several (40\%) of the residential to urban municipalities in this group had one or zero planning tools. Three (15\%) of these municipalities had only one planning tool and five (25\%) of these municipalities had no planning tools enacted. This data suggests that these municipalities experienced development without the utility of local land-use tools, and may have experienced less-informed decision making resulting in unwanted land-use changes. 


\section{Spatial Pattern}

Figure 26 below shows all of the municipalities discussed in the Municipalities sub-section above. However, only the land-use changes 'to urban' are mapped, as this transition was used to identify and rank the top 20 municipalities for each group. Each of the three land-use change transitions are represented distinctly. Forest to urban is represented by a solid gray color, AgGrass to urban is represented by a simple hatch pattern, and residential to urban is represented by stippling.

The spatial pattern of each of these land-use change transitions is revealing. Allegheny County continues to urbanize around its perimeter, mostly losing forested land to development. The construction of the new airport and the big-box retail phenomenon of the 1990's are thought to be significant factors in this transition. The proportional change in Washington County is also interesting, as the dominant change was also from forest to urban in municipalities that are adjacent to the Monongahela River Valley and those that are adjacent to similarly changing municipalities in Allegheny County. Fayette and Indiana Counties continued to urbanize, experiencing more residential to urban landuse changes, and Westmoreland County appears to be losing some of its agriculture communities to urbanization, as a few of its municipalities shared both residential to urban and AgGrass to urban transitions. The movement of development is clear along the 279 north corridor, north and west of the Ohio River, that leads from downtown Pittsburgh towards Cranberry Township, as the northwest corner of Allegheny County the southwest corner of Butler County and the southeast corner of Beaver County experienced significant development. The residential to urban land-use change depicted in Richhill Township, Greene County is thought to be mining activity, not urban activity. 
Figure 26 - Developing (Urbanizing) Municipalities

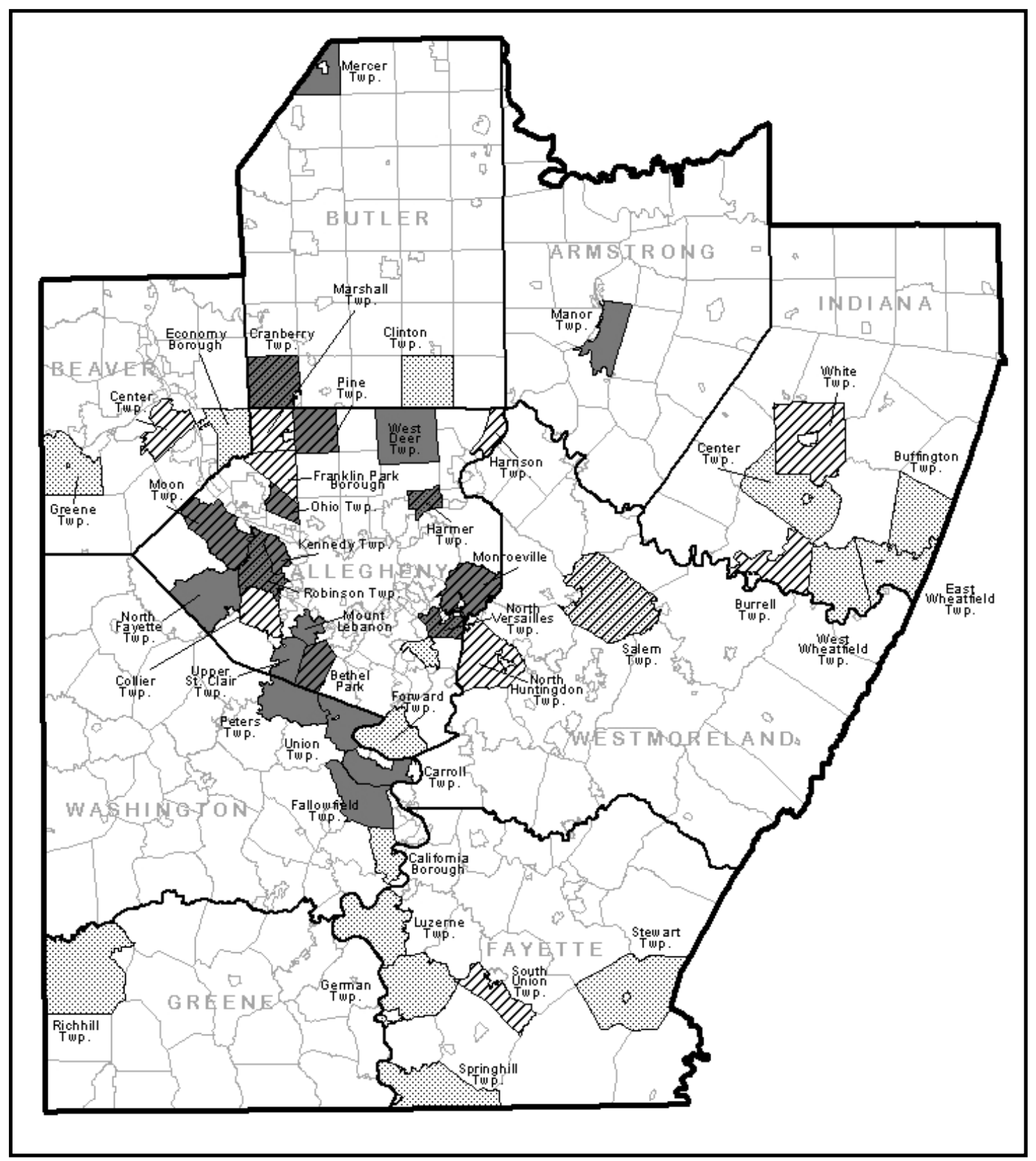

2.:. Residential to Urban

VIIA AgGrass to Urban

Forest to Urban 


\section{Comprehensive Viewpoint}

In order to discuss the relevance of this research as a whole, it is impossible to do so unless it is viewed comprehensively; and to research metropolitan regions adequately, one must approach urbanization as a process and this approach must be comprehensive in scope. Chapter 2 has shown that the urbanization process is an uneven one, as economic development see-saws throughout the region not only jumping scales but also producing, reducing and reproducing scales as various regimes and modes of production rise and fall - only to have new regimes and modes of production to take their place.

Chapter 3 reminds us that land-use planning theories and practices also rise and fall, often in a dialectic pattern of change that parallels the changes of regimes and production. Further, the objectives of planning practice changes too; where at times planning has been used as a tool to preserve modes of production by some political regimes in effort to stabilize, or spatially fix, large urban-economic districts, and other regimes used planning to facilitate changing social structures affected by economic restructuring. Chapter 4 should be read as a story that describes the changing role of land-use planning in the case study (Pittsburgh) by competing interests during most of the twentieth century.

Using the results of the remote sensing change detection analysis and the particular planning tools enacted by each of the 525 municipalities as inputs into the logistic regression model provided global statistics explaining the quantitative relationship between the individual land-use changes identified and particular planning policies. However, the descriptive analysis in the latter part of Chapter 6 
provided local qualitative and contextual interpretation of the statistics, which is necessary in order to turn this data into information. It is the hope of this author that this information is relevant and of interest to those individuals wanting to learn more about urban land-use, planning policy, uneven development and/or Pittsburgh. 
This page left intentionally blank. 


\section{CHAPTER 7 - Conclusion}

This research has shown that there were significant relationships between land-use policies and land-use changes in the Pittsburgh metropolitan area between 1992 and 2002. Other contextual and local events that occurred in each location are also presumed to have influenced types of development and rates of development during the study period. It should be noted again that this research is not intended to advocate the adoption, use or application of one particular land-use tool over another, the intent and goal of the research is clearly stated. However, by using the method performed in this research, metropolitan planning organizations and other planning bodies can access, visualize and interpret large amounts of data variation across hundreds of municipalities which enable decision makers to identify past changes and forecast future trends in land-use development and underdevelopment.

Examples of the utility of this research are evident in the analysis of the relationships between particular land-use policies and land-use changes. For instance, comprehensive plans were more likely to be found in those municipalities that experienced forested land-use change to any of the other three remaining landuses (Table 27). These positive relationships indicate that where forested land-use was lost to other land-uses, such transitions should have been in agreement with the goals set forth in the comprehensive plan adopted by these municipalities.

The most significant positive coefficient value in the sample is the relationship between zoning and the forest to urban land-use change transition (Table 28). In fact, there is a high likelihood that zoning is in place in those municipalities where any land-use change to urban took place. This is logical as these values tell us 
that urbanizing areas are more likely to have zoning, as zoning is a planning tool that is found most in existing urbanized areas (Figure 7).

The most evident relationship between subdivision regulations and land-use change in the study area was the positive relationship with land-uses changing from residential to any of the remaining three land-uses and vice versa, where urban, forest and AgGrass changed to residential. The highest valued coefficients represented AgGrass to residential, urban to residential, and forest to residential. The relationship between subdivision regulations and the opposite landuse change transitions (from residential to any of the remaining three land-uses) were insignificant in the statistical analysis. These polar relationships between subdivision regulation and changes to and from residential land-uses are interesting and yet expected as most subdivision of land parcels is done for the expansion of residential land use. Municipalities transitioning to residential land-uses are assumed to have already experienced some land-use changes prior to the study period that led to the adoption of subdivision regulations, and in these instances subdivision regulation begets subdividing land parcels. Inversely, the statistically insignificant relationships between subdivision and municipalities transitioning from residential to any of the remaining three land-uses informs us that more municipalities transitioned to residential land-uses and not out of residential land uses.

The most alarming relationships between subdivision regulations and land-use changes were the three transitions that experienced a negative relationship; forest to AgGrass, forest to urban, and urban to forest. Most interesting are the forest to AgGrass and forest to urban because these negative values tell us that those 
municipalities that experienced a loss of forest cover to AgGrass and to urban were less likely to have subdivision regulations in place. This analysis suggests that subdivision regulations are present in municipalities that experienced land-uses transitioning to residential, but the change from forest to urban or AgGrass changes were not influenced by subdivision regulations.

There is a majority of negative relationships between land-use changes and planning commissions, meaning that more variety of land-use transitions occurred in municipalities where planning commissions were absent. Again, the transition from forest to urban stands out and in this instance exhibited the highest negative relationship with municipalities that had planning commissions, suggesting that more forest areas were lost to urban uses in those municipalities that did not have a planning commission in place as opposed to those municipalities that did have a planning commission in place.

The five broad land-use categories used in this research represent the most general land-use classes important to local and regional political offices and economic developers. The choice and names of these categories were determined by the author based on his experiences in local and regional land-use planning in the study area over a five year period. These choices were based on the questions and comments made by different local political figures and citizens that attended dozens of public meetings. Most often, local decisions that were made using land-use data as a source of information were based on these five basic and colloquial categories.

Following this broad classification of the region's land-uses, closer examination and detection of other land-uses and land-covers within these broad 
categories would be useful for local decision making at the municipal unit. A major and evident weakness of this schema that may have greatly affected classification results was not considering surface mining as a land-use category. Surface mining should have been introduced as a target class because it is a prevalent land-use in the study area, especially in the southwest portion of the study area in Greene and Washington Counties, and it is often misrepresented as urban or residential land-use when classifying satellite imagery.

Weaknesses in the remote sensing approach are also noted. Using alternative remote sensing methods and techniques could have also produced better data for this analysis. For example, the classification of the remote sensing images could have benefited from additional image processing techniques. Absolute, or hard, classifiers such as the maximum likelihood technique used in this research are necessary when the need to classify every pixel is required. However, classifications using hard classifiers of satellite images representing urban areas are known to have lower accuracy levels than those classifications of the physical environment using the same date types (Mesev, 2003). Therefore, it is possible that by modifying the maximum likelihood technique by considering contextual, textural and spatial properties, or using other statistical operations would have produced more accurate results (Mesev, 2003). The adoption of other change detection analysis methods may have also yielded better results.

Future research will involve addressing the weaknesses explained in the remote sensing approach above, adding other socio-economic, environmental, and policy variables to the statistical analysis, and also distributing and investigating the 
results of the land-use changes by county boundaries instead of municipal boundaries, and by watershed boundaries instead of municipal boundaries.

Analysis at the county level would permit the use of other economic indicators reported at the county level as variables in the statistical analysis, such as county-wide economic development initiatives like Keystone Development Zones, county industrial park locations and utilization statistics, and other indicators such as public assistance and employment statistics. Aggregating the land-use change information at the county level instead of the local municipality would provide similar and relevant information for county and regional decision-makers.

The addition of more environmental indicators and policies when examining the results at the watershed unit is anticipated as being the most interesting future research. By statistically analyzing the land-use change information distributed at the watershed unit with temporal water quality data collected by the Pennsylvania Department of Environmental Protection, results should indicate where specific land-use changes that occurred may have direct relationships with changes in water quality over the same time period.

The major contribution gained from this empirical study is the conceptual understanding of how regulatory action results in development reaction. More abstractly, these results reveal how the urbanization process produces contradicting forces of public and private interests. Public forces are created to regulate land development for the 'public interest' and private forces develop land for the expansion of economic interests. 
In the Pittsburgh metropolitan area, scale is critical element in the regulation and exploitation of land resources. Pittsburgh’s extensive political fragmentation has led to extensive land-use policy fragmentation which has further led to extensive land-use fragmentation. The adoption of local municipal policy for local municipal land-use planning creates a regional land-use patchwork that represents the disconnect between regional land-use planning knowledge and regional land-use planning practice. Overall, this research provides empirical results regarding the interplay between land-use policy and land-use change. The significant results were informative and greater than expected. These results are not absolute or definitive, but they do provide a foundation for further analysis of the effect and consequence of land-use policy in relationship to land-use change. 


\section{Bibliography}

Ahlbrandt, Roger S. and Weaver, Clyde, 1987, "Public-Private Institutions and Avanced Technology Development in Southwestern Pennsylvania", Journal of the American Planning Association, 53: 449-458.

Alexander, E. 1984. After rationality, what? Journal of American Planning Association. Winter. $62-69$.

Allegheny Conference on Community Development (ACCD), 2005. http://www.alleghenyconference.org/public/cfm/homepage_accd/

Allmedinger, P. 2002. Planning in Postmodern Times (chapters 1 - 4). Routledge. London.

Bauman , J. F., and Muller, E. K. 1997. The Olmsteds in Pittsburgh: (Part II) shaping the progressive city. Pittsburgh History. 191-205.

Beauregard, R.A. 1989. Between modernity and postmodernity: the ambiguous position of US planning. Environment and Planning D: Society and Space. 7: $381-305$.

Beauregard, R.A. 1991. Without A Net: Modernist Planning and the Postmodern Abyss," Journal of Planning Education and Research 10(3): 189 - 194. 
Brenner, N. 1998. Between fixity and motion: accumulation, territorial organization and the historical geography of spatial scales. Environment and Planning D: Society and Space. $16:$ 459-481.

Brenner, N. 1997. Global, fragmented, hierarchical: Henri Lefebvre’s geographies of globalization. Public Culture. 10(1): 135-167.

Brooks, M. P. 1988. Four critical junctures in the history of the urban planning profession: an exercise in hindsight. Journal of the American Planning Association, 54: $241-248$.

Center for Rural Pennsylvania. 2001. Measuring the effectiveness of comprehensive planning and land use regulations in Pennsylvania. Pennsylvania General Assembly. Harrisburg.

Commonwealth of Pennsylvania. Pennsylvania Department of Community and Economic Development. Pennsylvania municipalities planning code. Harrisburg: General Assembly of the Commonwealth of Pennsylvania, 2001.

Congalton, R. G. 1991. A review of assessing the accuracy of classifications of remotely sensed data. Remote Sensing of the Environment. 37: 35-46. 
Cox. K. R. 1998. Spaces of dependence, spaces of engagement and the politics of scale, or: Looking for local politics. Political Geography. 17(1): 1-23.

Cox. K. R. 1996. The difference that scale makes. Editorial in Political Geography. 15(8): 667-669.

Cox. K. R. 1995. Globalisation, competition and the politics of local economic development. Urban Studies. 32(2): 213-224.

Cox. K. R. 1993. The local and the global in the New Urban Politics: A Critical Review. Environment and Planning D: Society and Space. 11: 433-448.

Cox. K. R. and Mair, A. 1991. From localized social structures to localities as agents. Environment and Planning A. 23: 197-213.

Cox. K. and Mair. A. 1988. Locality and community in the politics of local economic development. Annals of the American Association of Geographers. 78(2): 307-325.

Croissant, C. and Monroe, D. 2003. Zoning and fragmentation of agricultural and forest land use on residential parcels in Monroe county, Indiana. Geography Research Forum. Vol. 22, p. 91-109. 
Cullingworth, B. 1997. Planning in the USA: policies, issues, and processes. Routledge, New York.

Dalton, L. C. 1986. Why the rational paradigm persists: the resistance of professional education and practice to alternative forms of planning. Journal of Planning Education and Research. 5(3): 147 - 153.

Daly, Janet R. 1988. Zoning: It’s Historical Context and Importance in the Development of Pittsburgh. The Western Pennsylvania Historical Magazine. 71(2): 1988.

Dear, M. 1986. Postmodernism and planning. Environment and Planning D. Vol. 4, p. 367-384.

Escobar, A. 1992. Planning in "The Development Dictionary: A Guide to Knowledge as Power”, edited by Wolfgang Sachs. Zed Books. London.

Fung, T. 1990. An assessment of TM imagery for land-cover change detection. IEEE Transactions of Geoscience and Remote Sensing. 28(4); 681-684.

Fries, S. D. 1977. The Urban Idea in Colonial America. Temple University Press. Philadelphia. 
Giddens, A. 1984. The Constitution of Society. University of California Press. Berkeley.

Gondim, L. M. 1988. Planning practice within public bureaucracy: a new perspective on roles of planners. Journal of Planning Education and Research. 7(3).

Gordon, D. M. 1977. Class struggle and the stages of American urban development, in "Rise of the sunbelt cities" chapter 2, edited by Perry, D. and Watkins, A.

Grainger, A. 1999. The role of spatial scale in sustainable development. International Journal of Sustainable Development and World Ecology. 6: 251-264.

Haack, B., Bryant, N., Adams, S. 1987. An assessment of Landsat MSS and TM data for urban and near-urban land-cover digital C=classification. Remote Sensing of Environment. 21: 201-213.

Harper, R. E. 1988. Town development in early western Pennsylvania. The Western Pennsylvania Historical Magazine. 71(1): 3-27.

Harper, T. L. and Stein, S. M. 1995. Out of the postmodern abyss: preserving the rationale for liberal planning. Journal of Planning Education and Research. 14: $233-244$. 
Harvey, D. 2001. Spaces of capital: Towards a critical geography. Routledge. Oxford.

Harvey, D. 1998. On planning the ideology of planning in "Readings in planning theory”, chapter 8, edited by Scott Campbell and Susan S. Fainstein. Blackwell, Malden, Mass.

Harvey, D. 1989a. The urbanization of capital in “The urban experience”, chapter 1. Johns Hopkins University Press. Baltimore.

Harvey, D. 1989b. The place of urban politics in the geography of uneven capitalist development in "The urban experience", chapter 5. Johns Hopkins University Press. Baltimore.

Harvey, D. 1987. Flexible accumulation through urbanization. International Journal of Urban and Regional Research.

Harvey, David. 1982. The Limits to Capital. The University of Chicago Press. Chicago.

Harvey, D. 1978. The urban process under capitalism. International Journal of Urban and Regional Research. 101-131. 
Hays, Samuel, P. 2000. A history of environmental politics since 1945. University of Pittsburgh Press, Pittsburgh.

Hays, Samuel, P. 1989. Pittsburgh: How Typical? In "City and the Point: Essays on the Social History of Pittsburgh” edited by Hays, S. Pittsburgh, 385-405.

Hoch, C. 1994. Planning and Professional Authority in a Liberal Society in "What Planners Do: Power, Politics, and Persuasion”. Planners Press. Chicago. 1 22.

Howe, E. 1992. Professional roles and the public interest in planning. Journal of Planning Literature. 6(3): $230-248$.

Howitt, R. 1998. Scale as relation: musical metaphors of geographical scale. Area. 30(1).

Innes, J.E., and D.E. Booher. 1999a. Consensus building as role-playing and bricolage: Toward a theory of collaborative planning. Journal of American Planning Association. 65(1): 9-26.

Innes, J.E., and D.E. Booher. 1999b. Consensus building and complex adaptive systems: a framework for evaluating collaborative planning. Journal of American Planning Association. 65(4): 412-423. 
Jensen, J. R. and Cowen, D. C. 1999. Remote Sensing of Urban / Suburban Infrastructure and Socio-Economic Attributes. Photogrammetric Engineering and Remote Sensing. 65(5): 611-622.

Jensen, J. R., Cowen, D. J., Halls, J., Narumalani, S., Schmidt, J. J., Davis, B. A., and Burgress, B. 1994. Improved Urban Infrastructure Mapping and Forecasting for BellSouth Using Remote Sensing and GIS Technology. Photogrammetric Engineering and Remote Sensing. 60(3): 339-346.

Jensen, J. R. 1981. Urban Change Detection Mapping Using Landsat Digital Data. The American Cartographer. 8(2): 127-147.

Kawamura, Makoto, Jayamanna, Sanath, Tsujiko, Yuji. 1996. Relation between social and environmental conditions in Columbo, Sri Lanka and the urban index estimated by satellite remote sensing data. International Archives of Photogrammetry and Remote Sensing. 31(B7): Vienna, 321-326.

Khorram. S., Brockhaus, J. A., Chesire, H. M. 1987. Comparison of Landsat MSS and TM data for urban land-use classification. IEEE Transactions on Geoscience and Remote Sensing. GE-25(2): 238-243. 
Klosterman, R.E. 1999. The what if? Collaborative planning supports system. Environment and Planning B: Planning and Design. 26: 393-408.

Klosterman, R.E. 1985. Arguments for and against planning. Town Planning Review. 56(1): 5-20.

Klosterman, R.E. 1978. Foundations for Normative Planning. Journal of the American Institute of Planners. 44: 37-46.

Krumholz, N. 1982. A retrospective view of equity planning: Cleveland, 1969 - 1979. Journal of the American Planning Association. 48(4): 163 - 183.

Lefebvre, H. 1991. The Production of Space. Blackwell. London. Malden, Massachusetts.

Leica Geosystems, 2003 . The erdas field guide. Seventh edition. Leica Geosystems GIS and Mapping, LLC. Atlanta.

Levy, J. M., 1990. What local economic developers actually do: location quotients versus press releases. American Planning Association Journal. Spring153160. 
Levy, J. M. 1992 What has happened to planning? Journal of the american planning association. 58(1): 81-84.

Lindgren, D. T. 1985. Land Use Planning and Remote Sensing. Martinus Nijhoff Inc. Boston, 230 p.

Lo, C. P. 1997a. Application of Landsat TM data for quality of life assessment in an urban environment. Computers, Environment and Urban Systems 21(3-4): 259-276.

Lo, C. P. 1997b. Integration of Landsat TM and census data for quality of life assessment. Remote Sensing of Environment. 62(2): 143-157.

Lubove, R. 1996. Twentieth Century Pittsburgh: Volume II - The Post Steel Era. University of Pittsburgh Press, Pittsburgh.

Lubove, R. 1995. Twentieth Century Pittsburgh: Volume I - Government, Business and Environmental Change. University of Pittsburgh Press, Pittsburgh.

MacLeod, G and Goodwin, M. 1999. Space, scale and the state strategy: rethinking urban and regional governance. Progress in Human Geography. 23(4): 503-527. 
Masek, J. G., F. E. Lindsay, and S. N. Goward, 2000. Dynamics of urban growth in the Washington DC metropolitan area, 1973-1996, From Landsat Observations. International Journal of Remote Sensing, 21(18): 3473-3486.

McCaan, E. J. 2000. Collaborative visioning or urban planning as therapy? The politics of public-private policy making. The Professional Geographer. 53(2): 207-218.

McLaughlin, G. E. 1938 (reprinted 1970). Growth of American manufacturing areas: a comparative analysis with special emphasis of trends in the Pittsburgh district. University of Pittsburgh. Pittsburgh.

Mesev, V. 2003. Urban land use uncertainty - Bayesian approaches to urban image classification in "Remotely Sensed Cities" chapter 9, edited by Victor Mesev. Taylor and Francis. New York.

Moore, T. 1978. Why allow planners to do what they do? A justification from economic theory. Journal of the American Institute of Planners 44(4): 387-398.

Mouat, D. A., Mahin, G. G., and Lancaster, J. 1993. Remote sensing techniques in the analysis of change detection. Geocarto International. 2: 39-50. 
Muller, Edward K. 2001. Industrial Suburbs and the Growth of Metropolitan Pittsburgh, 1870-1920. Journal of Historical Geography. 27(1): 58-73.

Muller, E. K. and Bauman, J. F., 1997. The Olmsteds in Pittsburgh: (Part I) landscaping the private city. Pittsburgh History. 122-141.

Muller, E. K. 1996. The Pittsburgh Survey and “Greater Pittsburgh”: A Muddled Metropolitan Geography, in "Pittsburgh Surveyed”, chapter 5. Edited by Greenwald and Anderson. University of Pittsburgh Press, Pittsburgh.

Palmer, T. 1986. Endangered Rivers and the Conservation Movement. University of California Press. Berkely.

Pennsylvania Economy League. 2005. http://www.pelwest.org/

Pløger, J. 2001. Public participation and the art of governance. Environment and Planning B: Planning and Design. 28: 219-241.

Rodriguez, A., Martinez, E., Guenage, G. 2001. European Urban and Regional Studies. 8(2): 161-178.

Rogerson, P. A. 2004. Statistical method for geography. Sage Publications. London. 
Ryznar, R. M. and Wagner, T. W. 2001. Using remotely sensed imagery to detect urban change: viewing Detroit from space. APA Journal 67(3): 327-336.

Singh, A. 1989. Digital change detection techniques using remotely-sensed data. International Journal of Remote Sensing. 10(6): 989-1003.

Smith, N. 2002 American Empire: Roosevelt's Geographer and the Prelude to Globalization. University of California Press. Berkeley.

Smith, N. 2000. Gentrification, the frontier, and the restructuring of urban space in "Readings in urban theory", chapter 13 (reprinted from 'Gentrification of the City’, 1986) Blackwell. Malden, Massachusetts.

Smith, N. 1992. Geography, difference and the politics of scale in "Postmodernism” chapter 3, edited by Doherty, J., Graham, E., Malek, M. Macmillan.

Smith, N. 1990. Uneven development: nature, capital and the production of space. $2^{\text {nd }}$ edition. Blackwell. Malden, Massachusetts.

Smith, M.P. 1988. Looking for global spaces in local politics. Political Geography. 17: 35-40. 
Smith, Roland M. 1975. The Politics of Pittsburgh Flood Control, 19081936. Pennsylvania History XLII(1): 5-24.

Smith, Roland M. 1977. The Politics of Pittsburgh Flood Control, 19361960. Pennsylvania History XLIV(1): 3-24.

Southwestern Pennsylvania Commission. 2004. http://www.spcregion.org

Stewman, S. and Tarr, J. A. 1982. Four Decades of Public-Private Partnerships in Pittsburgh in Public-Private Partnership in American Cites edited by Fosler, R. S. and Berger, R. A. D.C. Heath, Lexington, 59-127.

Storper, M. and Walker, R. 1987. The capitalist imperative: territory, technology and industrial growth. Blackwell. Malden, Massachusetts.

Sustainable Pittsburgh. 2002. Southwestern Pennsylvania Citizens’ Vision for Smart Growth: Strengthening Communities and Regional Economy, V. 1. http://www.sustainablepittsburgh.org/NewFrontPage/Citizens_Vision.html

Swyngedouw, E. 1997. Neither Global nor Local "Glocalization” and the Politics of Scale in “Spaces of Globalization” chapter 6, edited by Kevin Cox. Guilford. New York. 
Tewder-Jones, M. and Allmendinger, P. 1998. Deconstructing communicative rationality: a critique of Habermasian collaborative planning. Environment and Planning A. 30: 1975-1989.

Toll, D. 1985. Effect of Landsat Thematic Mapper Sensor Parameters on Land Cover Classification. Remote Sensing of the Environment. 17: 129-140.

US Census Bureau, 2004. Statistical Abstract of the United States. http://www.census.gov

US Geologic Survey, 2005. National Landsat Archive Production System (NLAPS). http://edc.usgs.gov/guides/images/landsat_tm/nlaps.html

US Geologic Survey. 10/02/1992. Landsat TM Path 17 Row 32, Precision Geocorrected using a 4-point cubic convolution resampling method. EROS Data Center, Sioux Falls, SD.

US Geologic Survey. 10/06/2002. Landsat TM Path 17 Row 32, Precision Geocorrected using a 4-point cubic convolution resampling method. EROS Data Center, Sioux Falls, SD. 
Vogelmann, J.E., Sohl, T. and Howard, S.M. 1998. Regional

Characterization of Land Cover Using Multiple Sources of Data. Phogrammetric Engineering and Remote Sensing. 64(1): 45-75.

Walker, R. and Lewis, R. D. 2001. Beyond the crabgrass frontier: industry and the spread of North American cities, 1850-1950. Journal of Historical Geography. 27(1): 3-19.

Webster, C. and Hirsch, J. 1992. Some urban measurements from SPOT data: urban life quality indices. International Journal of Remote Sensing. 13(17): 3251-3261.

Webster, C.J. 1996. Population and dwelling unit estimates from space. Third World Planning Review 18(2): 155-176.

Wildavsky, A. 1973. If planning isn’t everything, may be it’s nothing. Policy Sciences. 4: 127 -1 53.

Xiuwan, C. 2002. Using remote sensing and GIS to analyze land cover change and its impacts on regional sustainable development. International Journal of Remote Sensing. 23(1), pp. 107-124. 
Zhoa, B, Nakagoshi, N, Chen, J., Kong, L. 2003. The impact of urban planning on land use and land cover in Pudong of Shanghai, China. Journal of Environmental Science. 15(2), pp. 205-214. 
This page left intentionally blank. 


\section{Richard J. Hoch}

1099 University Drive

Dunbar, PA 15431

(304) 685 - 1355

RichardHoch@gmail.com

\section{Education}

\begin{tabular}{ll}
\hline \hline 8/99 - present & $\begin{array}{l}\text { Ph.D. in Geography (Regional Development and Planning), } \\
\text { West Virginia University (WVU). . }\end{array}$ \\
$8 / 97-6 / 99$ & $\begin{array}{l}\text { M.A. in Geography (Geographic Information Systems \& Remote Sensing), } \\
\text { WVU. }\end{array}$ \\
$8 / 91-12 / 92$ & $\begin{array}{l}\text { B.A. in History (Environmental \& Industrial), } \\
\text { University of Pittsburgh. }\end{array}$ \\
Research Specialties
\end{tabular}

- Land-use Planning Theory and Practice

- Regional Development

- Geographic Information Systems and Remote Sensing

- Watershed Management

- Urban \& Economic Development

\section{Professional Employment}

3/05 - present Geospatial Manager, Canaan Valley Institute.

7/04-3/05 Geospatial Coordinator, Canaan Valley Institute.

12/03 - 6/04 Strategic Planner / GIS Analyst, Schwan’s Food Company.

5/00 - 8/03 Land-use Planner / GIS Specialist, Skelly \& Loy, Engineers and Consultants

8/00 - 12/01 Instructor, Department of Geology and Geography, WVU.

8/98 - 4/00 Graduate Teaching Assistant, Department of Geology and Geography, WVU. 


\section{Teaching Experience}

8/01 - 12/01 Instructor, Climate and Environment.

1/01 - 4/01 Instructor, Urban Geography.

8/00 - 12/00 Instructor, World Regional Geography.

1/00 - 5/00 Teaching Assistant for two courses: Introduction to Human Geography, and Rural and Regional Development.

8/99 - 12/99 Lab Instructor for Remote Sensing of the Environment.

8/98 - 8/99 Teaching Assistant for five courses: Urban and Regional Planning, Economic Geography, Geography of Europe, Introduction to Remote Sensing, and Climate and Environment.

\section{Awards}

Endowed Doctoral Teaching Fellowship. Eberly College of Arts and Sciences, 2001.

Endowed Doctoral Teaching Fellowship. Eberly College of Arts and Sciences, 2000.

Outstanding Graduate Teaching Assistant. Department of Geography, Eberly College of Arts and Sciences, 2000.

Outstanding Graduate Teaching Assistant. Department of Geography, Eberly College of Arts and Sciences, 1999.

\section{External Funding Awards}

Commonwealth of Pennsylvania Growing Greener Program Grants:

20024 projects, total grant awards: $\$ 150,000$

20012 projects, total grant awards: $\$ 87,000$

20002 projects, total grant awards: $\$ 86,000$

\section{Conference Presentations}

Hoch, R. J. 2005. Panelist in session entitled: Making Your Own Way: Grant Proposal Writing for Graduate School and Beyond (sponsored by the Jobs in Geography Committee). Annual meeting of the Association of American Geographers, Denver, Colorado.

Hoch, R. J. 2004. Assessing the Relationship Between Local Land-use Policy and Land-use Change in Metropolitan Pittsburgh. Annual meeting of the Association of American Geographers, Philadelphia, PA.

Hoch, R. J. 2000. Uneven Development of Nature: An Historical Geography of Ohiopyle State Park. Annual meeting of the Association of American Geographers, Pittsburgh, PA. 
Hoch, R. J. 2000. Panelist in session entitled: Developing Geographies, Graduate Research on Regional Development and Planning (sponsored by Regional Development and Planning Specialty Group). Annual meeting of the Association of American Geographers, Pittsburgh, PA.

Hoch, R. J. 1999. Producing a Nature Landscape: A Case Study of Ohiopyle State Park. Annual meeting of the Middle States Division of the American Association of Geographers, West Chester, PA.

\section{Invited Presentations}

$2^{\text {nd }}$ Annual Appalachian Remote Sensing Conference, 2005. Coordinated presentation entitled, LiDAR Operations, Processing and Applications.

West Virginia Department of Environmental Protection, 2003. Presentation entitled, Stormwater Management and Asset Assessment Utilizing Geographic Information Systems: Preparing for the EPA MS4, Phase II Requirement. Invited to speak at stormwater program's statewide forum for municipal officials to introduce the merits of adopting a GIS for day-today management.

Connellsville Area High School, 2003. New Methods in Teaching Ecology in the Classroom: A GIS Approach. Invited speaker for faculty in-service day.

\section{Service}

Board of Directors (Secretary), Mountain Watershed Association. Contact: Beverly Braverman (2002 - 2003).

Volunteer, The Institute for the History of Technology \& Industrial Archaeology. Serve on an as-needed volunteer basis for GIS and RS project needs. Worked on GIS projects for the National Road (US Route 40) and the Northbend Rail-trail through central West Virginia. Contact: Daniel Bonenberger.

Volunteer, Ohiopyle State Park. Contact: Barbara Drbal Wallace.

Graduate Representative, Geography Graduate Program Committee, WVU, (8/98 - 5/02).

Graduate Representative, Graduate Student Council, WVU, (8/98 - 5/00).

Graduate Representative, Search Committee for Geography Program GIS and Natural Resources faculty position, (Spring, 2002).

Co-Organizer of field trip (w/ Lizabeth Pyle) for national meeting of American Association of Geographers, Pittsburgh, April 5, 2000. Field trip title: Recreational Retreats and Rural Landscapes in the Laurel Highlands; involved with all aspects of organizing event. Field trip's focus was to compare different interpretations of nature - from private (Fallingwater) to public (Ohiopyle State Park) to communal (New Meadow Run Bruderhof) to elite (Nemacolin Woodlands Resort). 
Natural Stream Channel Design / Applied Fluvial Geomorphology (Rosgen I), April 2005. Wildland Hydrology Consultants.

REALM Survey Suite and ALTM Digital Aerial Camera, Data Processing Training Program

March 2005. Optech Incorporated.

Presenting Data and Information, September, 2004. Edward Tufte.

International Watershed Remote Sensing Workshop, sponsored by the European Union and the US Department of Education, May 2001. Involved the use of satellite imagery to monitor land-use practices within watersheds; held in Xanthi, Greece.

\section{Technical Documents}

Raccoon Creek Watershed Abandoned Mine Drainage (AMD) Survey and Preliminary Restoration Plan, EPA Section 104(b)(3) Document. Primary Investigator. Prepared for Raccoon Creek Watershed Association, Washington, PA, 2000.

Indian Creek Watershed River Conservation Plan (RCP). Primary Investigator. In compliance with the Pennsylvania DCNR Watershed Management Registry. Prepared for the Mountain Watershed Assoc., Melcroft, PA. Successfully listed on the Pennsylvania Rivers’ Registry. Entire plan prepared integrating GIS.

Upper Chartiers Creek River Conservation Plan (RCP). Primary Investigator. In compliance with the Pennsylvania DCNR Watershed Management Registry. Prepared for Chartiers Creek Nature Conservancy, Washington, PA. Entire plan prepared integrating GIS.

Cross Creek Watershed Assessment, Protection and Restoration Plan. Project Manager and Primary Investigator. Prepared for the Cross Creek Watershed Association, Avella, PA. Entire plan prepared integrating GIS.

Garrett County, MD Landfill. Project Manager and Primary Investigator. Contracted to produce mapping of landfill project area.

Indian Creek Watershed Acid Mine Drainage and Abandoned Mine Land Mapping. Project Manager and Primary Investigator. Acquired agency and field data to produce high quality, accurate and precise map of AMD and AML sites throughout the watershed atop a USGS 1:24,000 topographic base map.

Fuel Survey (Confidential). Primary Investigator. Produced maps and spreadsheets depicting all coal refuse from abandoned mine lands that had potential as a fuel resource for proposed power plant. Determined traveling distance from refuse pile to proposed site.

Mill Run Creek, PA Fluvial Geomorphology Survey and Assessment. Created GIS application for production of high-quality field maps for survey crew by fusing data from DOQQ's, DRG's and stream data from the Southwestern Pennsylvania Commission (SPC). 
Upper Indian Creek Fluvial Geomorphology Assessment. Performed fieldwork to survey stream health using Rosgen protocol and USDA Visual Assessment guidelines. Delineated stream reaches and types and displayed results on 1:24,000 Digital Raster Graphs.

MTBE (methyl tertiary-butyl ether) Study of Northern West Virginia. Created maps to indicate shortest traveling distance between water intake sampling sites. This use of GIS in the budgetary stage of proposal writing enabled firm to estimate with a much higher degree of accuracy, the costs associated with traveling.

Hinton, WV Area Fluvial Geomorphology Study for Highway Upgrades. Determined areas of special concern by applying project scope criteria. Provided maps and analysis for project by determining minimum distance buffers of stream channels from road surfaces. Performed by applying buffers to streams and roadways over a digital elevation model. Prepared for WV $\mathrm{DOH}$.

Environmental Assessment, United States Department of Energy, Pittsburgh PA and Morgantown WV. Primary Investigator. Prepared Environmental Assessment (EA) for both facilities, utilizing federal guidelines necessary when preparing NEPA documentation. Prepared for US DOE / NETL.

Donohoe Creek Watershed Assessment, Hempfield Twp., Westmoreland County. Prepared a set of maps using local, state, county and field-collected data to present the physical and cultural characteristics of the watershed. Also analyzed impervious surface areas to determine areas of concern to high-flow runoff. Prepared for Westmoreland County Conservation District. This watershed is to be used as a model for the WCCS to educate citizens on the benefits gained through conservation efforts.

\section{Computer Skills}

Hardware: PC (Windows) and Macintosh platforms, Trimble Geo-Explorer III GPS, ALTM 3100 .

GIS Software: ArcGIS 9, Arc View 3.x, ArcView extensions Network Analyst, Spatial Analyst, 3-D Analyst, ArcIMS, MapInfo Professional 7.0.

Remote Sensing / Image Processing Software: ERDAS Imagine 8.x, IDRISI Kilimanjaro, Adobe Photo Shop, REALM Survey Suite, TerraScan/TerraModeler, POSPac, QT Modeler

Other Software: Microsoft Office Suite, Corel Word Perfect, Minitab, SAS, Bentley Microstation.

\section{Professional Organizations}

- Association of American Geographers

- American Planning Association

- Pennsylvania Planning Association

- Pennsylvania Geographical Society

- Pennsylvania Mapping and Geographic Information Consortium (PaMagic) 